\title{
Biological Flora of Central Europe: Baldellia ranunculoides (Alismataceae)
}

\author{
Gregor Kozlowski ${ }^{a, *}$, R. Andrew Jones ${ }^{\mathrm{b}}$, Flora-Lise Nicholls-Vuille \\ ${ }^{a}$ Department of Biology and Botanic Garden, University of Fribourg, Ch. du Musée 10, CH-1700 Fribourg, Switzerland \\ ${ }^{\mathrm{b}}$ Countryside Council for Wales, Plas Gogerddan, Penrhyncoch, Aberystwyth, Ceredigion SY23 3EE, Wales, UK \\ ${ }^{\mathrm{c} C e n t r a l ~ B i o l o g i c a l}$ Laboratory, University of Zürich, Sternwartstrasse 6, CH-8091 Zürich, Switzerland
}

\begin{abstract}
Baldellia ranunculoides (L.) Parl. (Alismataceae) is a taxonomically problematic aquatic plant with an historically illdefined distribution and global conservation status. This paper finds morphological, ecological and molecular evidence for two distinct taxa, probably best described as subspecies: (1) B. ranunculoides subsp. ranunculoides and (2) B. ranunculoides subsp. repens and provides detailed distribution data on their overlapping range, in different habitats, across the cool, high rainfall areas of western Europe and west Mediterranean. The two subspecies are amongst the relatively large number of threatened European and north Africa aquatic plants and this paper provides a systematic review of their relative conservation pressures and management needs, with particular emphasis on the status of both taxa in central Europe. Other observations indicate probable evolutionary relationships within B. ranunculoides s.l. and its associated taxa and the review points out where these and other research topics could potentially be pursued.
\end{abstract}

Keywords: Endangered species; Aquatic plants; Atlantic phytogeographical element; Baldellia ranunculoides subsp. ranunculoides; Baldellia ranunculoides subsp. repens

\section{Introduction}

Baldellia is one of several small genera within an exclusively aquatic plant family, the Alismataceae. It has two generally well-recognised species, B. ranunculoides (L.) Parl. and B. alpestris (Coss.) Vasc. but there is disagreement over further taxonomic divisions. Several authors recognise a third species, B. repens (Lam.) van Ooststroom, which others simply treat as a subspecies (B. ranunculoides subsp. repens (Lam.) À. Löve \& D.

\footnotetext{
${ }^{*}$ Corresponding author. Tel.: +48263008842 ; fax: +48263009740 .

E-mail address: gregor.kozlowski@unifr.ch (G. Kozlowski).
}

Löve) or even as a variety of $B$. ranunculoides. The situation is often just overlooked (e.g. Dandy, 1980).

The taxonomic difficulties in B. ranunculoides s.l. have hindered conservation decisions and priorities although (as with many aquatic plants) all taxa show signs of a serious decline, through habitat destruction, rangefragmentation and other anthropogenic change. We have undertaken a systematic and through review of Baldellia in the literature, the herbaria of the University of Zürich, Swiss Federal Institute of Technology Zürich (ETH-Zürich), the Botanical Garden of Geneva, the Natural History Museum of Fribourg and the University of Neuchâtel together with unpublished data and personal observations to provide a comparative review 
of the ecology, systematics and range status of both subspecies of B. ranunculoides. Such detailed ecological and morphological separation of both taxa will help to better understand their different causes of decline as well as several other taxonomic, evolutionary, ecological and biogeographic issues in the genus Baldellia.

\section{Taxonomy}

The genus Baldellia belongs to a monocotyledonous family, the Alismataceae in the Alismatales: one of the very few exclusively aquatic plant orders. The Alismatales mainly consist of marsh plants and freshwater aquatics with a few marine members, e.g. Enhalus, Halophila and Thalassia, family Hydrocharitaceae (Dahlgren et al., 1985; Cook, 1990; Les et al., 1997). The taxonomic relationships of the Alismatales are still not completely understood (Markgraf, 1981; Tomlinson, 1982; Dahlgren et al., 1985) but the order - and especially the Alismataceae and Butomaceae - has often been regarded as an especially ancient plant group and perhaps amongst the most primitive of the monocotyledons. It has, for instance, numerous atypical characteristics and also many affinities with the dicotyledonous Nymphaeales (e.g. Nymphaeaceae) and Ranales (e.g. Ranunculaceae) (Wilder, 1975; Cronquist, 1981; Markgraf, 1981; Chase et al., 1993; Janssen and Bremer, 2004), although Tomlinson's study of anatomy in the Helobiae indicates numerous differences between the Ranunculaceae and Alismataceae (Tomlinson, 1982). He concludes that modern anatomical and morphological studies challenge some of these views of primitiveness. Dahlgren et al. (1985) have also proposed that morphological similarities, especially with Nymphaeaceae, could simply be the result of convergent evolution, which is especially prevalent in aquatic habitats.

The Alismataceae is a family of perennial - or more rarely annual - herbs, mostly found in the northern hemisphere and with a centre of diversity in the tropics and subtropics (Dahlgren et al., 1985; Cook, 1990). There is no consensus on the total number of genera and species but, with 10-14 genera and about 90-100 species it is certainly one of the smaller plant families (Markgraf, 1981; Cook, 1990; Haynes et al., 1998). For further information on the Alismataceae see e.g. Buchenau (1882, 1903), Cook (1990), Casper and Krausch (1980), Tomlinson (1982) and Dahlgren et al. (1985).

Baldellia is one of several small genera in the Alismataceae (like Damasonium and Luronium) that have been split from the original Linnaean genus Alisma. Unlike these other genera, though, Baldellia has had a notably controversial and prolonged taxonomic history and the identity of at least one species, B. ranunculoides and several of its infraspecific taxa has been equally complex (Table 1). These factors have significantly affected our understanding of the biogeography, ecology and conservation status of the relevant taxa.

Linnaeus (1753) included the species now called Baldellia ranunculoides in the genus Alisma (Table 1), but it was later transferred by Engelmann (1848) into the newly described (and otherwise American) genus Echinodorus. Very soon afterwards, however, Parlatore (1854) noted several differences in flower characters between the supposed Old World member of this genus and its New World counterparts. Significantly, the European species had six stamens and a terminal style whilst New World Echinodorus species usually had more

Table 1. Historical species and subspecies nomenclature in the genus Baldellia showing the first and the most influencial descriptions

\begin{tabular}{|c|c|}
\hline Taxon/synonyms & Reference \\
\hline \multicolumn{2}{|c|}{ B. ranunculoides subsp. ranunculoides } \\
\hline Alisma ranunculoides & Linnaeus (1753) \\
\hline $\begin{array}{l}\text { Echinodorus } \\
\text { ranunculoides }\end{array}$ & Engelmann (1848) \\
\hline Baldellia ranunculoides & Parlatore (1854) \\
\hline $\begin{array}{l}\text { Echinodorus } \\
\text { ranunculoides var. } \\
\text { ranunculoides }\end{array}$ & Glück (1905) \\
\hline Baldellia ranunculoides & Löve and Löve (1961b), Casper and \\
\hline \multicolumn{2}{|c|}{ B. ranunculoides subsp. repens } \\
\hline Alisma repens & $\begin{array}{l}\text { de Lamarck (1786), Cavanilles } \\
\text { (1791) }\end{array}$ \\
\hline Echinodorus & Smith (1828) a , Glück (1905), \\
\hline ranunculoides var. repens & Ascherson and Graebner (1913) \\
\hline $\begin{array}{l}\text { Echinodorus } \\
\text { ranunculoides forma } \\
\text { repens }\end{array}$ & Buchenau (1903) \\
\hline Echinodorus repens & Kern and Reichgelt (1950) \\
\hline Baldellia repens & $\begin{array}{l}\text { van Ooststroom (1956), Lawalrée } \\
\text { (1959) }\end{array}$ \\
\hline Baldellia ranunculoides & Löve and Löve (1961b), Casper and \\
\hline ssp. repens & Krausch (1980) \\
\hline \multicolumn{2}{|l|}{ B. alpestris } \\
\hline Alisma alpestre & Cosson (1864) \\
\hline Echinodorus alpestris & Micheli (1881) \\
\hline $\begin{array}{l}\text { Echinodorus } \\
\text { ranunculoides "forma } \\
\text { alpina" }\end{array}$ & Buchenau (1903) \\
\hline Baldellia alpestris & $\begin{array}{l}\text { Lainz (1967), Vasconçellos (1970), } \\
\text { Casper and Krausch (1980) }\end{array}$ \\
\hline
\end{tabular}

aThe material described by Smith (1828) as "var. repens" possibly included hybrids between $B$. ranunculoides subsp. ranunculoides and subsp. repens. This might also be the taxon described by Molina Abril et al. (1994) as B. ranunculoides subsp. cavanillesii. 
than six stamens with lateral styles. He used these differences to describe a new genus, which he named Baldellia, in honour of the governor of Tuscany, Bartolommeo Bartolini-Baldelli (Parlatore, 1854; Markgraf, 1981).

This taxonomy was not, however, universally accepted and the two names Echinodorus and Baldellia continued to be used interchangeably in Europe over the next hundred years (Table 1). It is only in the last half century or so that monographs and studies of the Alismataceae have generally accepted the separation and, until recently, most of these still assumed a close relationship between the two genera (e.g. Cook, 1990). In fact, more recent molecular, chromosomal and anatomical studies demonstrate that Baldellia is actually more closely related to Alisma, Damasonium and Luronium (Hess et al., 1977; Uchiyama, 1989; Les et al., 1997; Posluszny et al., 2000; Charlton, 2004; Chen et al., 2004). Notably, perhaps, the only reported intergeneric hybrids of Baldellia in the wild have been with Alisma plantago-aquatica and Alisma lanceolatum (Hess et al., 1977; Markgraf, 1981).

Although the generic identity of Baldellia has been recently resolved, its specific (and intraspecific) characters present a continuing difficulty (Table 1). The neoendemic B. alpestris (Coss.) Vasc. of northwest Iberia is relatively uncontroversial (Vasconçellos, 1970; Cook, 1983; Moreno Saiz and Sainz Ollero, 1992) and does not require further discussion here but the taxonomic history of $B$. ranunculoides s.l. and, especially, its prostrate "repens" variant has had a very erratic course. The reasons for this seem to have been difficulties with the original description and, perhaps, the availability of material (Jones, 2006) but it is also likely that intermediates (or hybrids) have added to the confusion.

The first description of a distinctively stoloniferous, large-flowered plant was published by de Lamarck (1786), as Alisma repens, from material collected in La Calle (modern El Qala or El Kala) in northeast Algeria. It was illustrated shortly afterwards by Cavanilles (1791). There are a few subsequent reports of this species from elsewhere in Europe (e.g. Davies, 1813) but it was soon reduced to a variety of $A$. ranunculoides var. repens with the discovery of apparent intermediates (Smith, 1828).

This taxonomic perception remained unchanged up to Buchenau's first comprehensive monograph on the Alismataceae (1903) and Glück's (1905) very thorough treatment of aquatic plants (which maintained repens as just one variety in a series). Ascherson and Graebner (1913) subsequently adopted the more conservative idea of just two varieties (Echinodorus ranunculoides var. ranunculoides and $E$. ranunculoides var. repens) in their influential Synopsis and, for the first half of the 20th century this taxonomic view prevailed.
The major reassessment came about through a more detailed description of material from the Dutch/Belgian border by Kern and Reichgelt (1950), which provided a range of new and consistent characters for subsp. repens. Kern and Reichgelt chose to restore this taxon to species status (in Echinodorus) and, subsequently, van Ooststroom (1956) was able to reassign it to Baldellia. The combination $B$. repens has been generally taken up in Floras and publications from north Europe and the Benelux countries and is occasional in France and elsewhere (e.g. Lawalrée, 1959; van Rompaey and Delvosalle, 1972; Cools, 1989; Lindblad and Ståhl, 1989; Ingelög et al., 1991; Aronsson, 1999; Lid and Lid, 2005).

By contrast, central and northwest European sources tend to regard this plant - if it is recognised at all - as a subspecies of B. ranunculoides (e.g. Casper and Krausch, 1980; Vuille, 1988; Triest and Vuille, 1991; Jones, 2006). This difference of perception could be significant for a number of reasons (see, for instance, 'Conservation threats and status' below) but is not very easy to explain - or assess. Both taxa do indeed have clear and consistent differences (see Table 2) but these also occasionally overlap, both in terms of habitats and morphology. There is also evidence of morphological and genetic intermediates (Vuille, 1988; Triest and Vuille, 1991; Bocchieri and Iiriti, 2003; Jones, 2006; personal observations) which, it will be remembered, was one of the main reasons for the early reassessment of this taxon as a variety (Smith, 1828). Additionally, Molina Abril et al. (1994) have recently described a new subspecies of $B$. ranunculoides (subsp. cavanillesii) from Spain, which also seems to have some characteristics of an intermediate. Whilst this taxon has appeared in some local publications (e.g. Sardinero Roscales, 1994) its taxonomic status probably needs further investigation (although we have not had the opportunity to do so here). These intermediates seem to be more frequent in edge-of-range populations (perhaps where ecological barriers have tended to break down) and it is likely that they have contributed here to some taxonomic uncertainty.

If, as seems probable, intermediates are best understood as widespread, naturally occurring hybrids, there is some justification for regarding their parent taxa as relatively close. There is clearly a need for more work (especially of a molecular genetic nature) on the issue but, from the preceding taxonomy and, especially, the presence of intermediates this review accepts the more conservative position of one species, Baldellia ranunculoides, divided into two subspecies: (1) B. ranunculoides subsp. ranunculoides, a palaeoendemic taxon found throughout western Europe and the Mediterranean region, and (2) B. ranunculoides subsp. repens, partially sympatric with subsp. ranunculoides but with different ecology (Lawalrée, 1959; Casper and Krausch, 1980). As 
Table 2. Morphological and biological differences between B. ranunculoides subsp. ranunculoides and subsp. repens (based on Kern and Reichgelt, 1950; Lawalrée, 1959; Casper and Krausch, 1980; Vuille, 1988; Triest and Vuille, 1991; Lindblad and Ståhl, 1990; Jones, 2006; and personal observations)

\begin{tabular}{|c|c|c|}
\hline Characteristics & Subsp. ranunculoides & Subsp. repens \\
\hline Plant & $\begin{array}{l}\text { Up to } 60 \mathrm{~cm} \text { high, } \\
\text { erect }\end{array}$ & $\begin{array}{l}\text { Up to } 20 \mathrm{~cm} \text { high, } \\
\text { creeping }\end{array}$ \\
\hline Leaf blades & Narrowly lanceolate & $\begin{array}{l}\text { Narrowly lanceolate to } \\
\text { ovate }\end{array}$ \\
\hline $\begin{array}{l}\text { Vegetative } \\
\text { reproduction }\end{array}$ & $\begin{array}{l}\text { Corm-like buds, } \\
\text { without inflorescence } \\
\text { stolons (runners) }\end{array}$ & $\begin{array}{l}\text { Inflorescence stolons } \\
\text { (runners), corm-like } \\
\text { buds less frequent }\end{array}$ \\
\hline $\begin{array}{l}\text { Peduncle } \\
\text { diameter }\end{array}$ & Up to $3 \mathrm{~mm}$ thick & Up to $1 \mathrm{~mm}$ thick \\
\hline $\begin{array}{l}\text { Flowers/ } \\
\text { pseudowhorl }\end{array}$ & $6-15(-27)$ & $(0-) 2-4(-6)$ \\
\hline Inflorescence & $\begin{array}{l}\text { Erect or decumbent, } \\
\text { not rooting at the } \\
\text { nodes }\end{array}$ & $\begin{array}{l}\text { Creeping, rarely erect, } \\
\text { rooting at the nodes }\end{array}$ \\
\hline Pedicels & $+/-$ straight & $+/-$ curved \\
\hline \multirow[t]{3}{*}{ Petals } & White (rarely pink) & Pink (rarely white) \\
\hline & Small $(6.5 \times 7 \mathrm{~mm})$ & $\begin{array}{l}\text { Long }(8.5 \mathrm{~mm}) \text { and } \\
\text { wider }(10 \mathrm{~mm})\end{array}$ \\
\hline & Not overlapping & Overlapping \\
\hline Sepals & $2.5-3.6 \mathrm{~mm}$ & $3-4.5 \mathrm{~mm}$ \\
\hline Flowers & $\begin{array}{l}\text { Diameter (8)13-15(18) } \\
\mathrm{mm}\end{array}$ & Diameter $15-22 \mathrm{~mm}$ \\
\hline Anthers & Small $(0.8-1.0 \mathrm{~mm})$ & Long $(1.1-1.5 \mathrm{~mm})$ \\
\hline $\begin{array}{l}\text { Carpel } \\
\text { number }\end{array}$ & 25-45 (average of 33) & 15-20 (average of 18) \\
\hline Fruit-heads & (4-)6-8 mm diameter & 4-5 $\mathrm{mm}$ diameter \\
\hline $\begin{array}{l}\text { Pollen grain } \\
\text { number }\end{array}$ & $\begin{array}{l}\text { Low }(500-800 \text { per } \\
\text { anther) }\end{array}$ & $\begin{array}{l}\text { High (1000-3000 per } \\
\text { anther) }\end{array}$ \\
\hline $\begin{array}{l}\text { Pollen/ovule } \\
\text { ratio }\end{array}$ & Low (100-250) & High (500-1000) \\
\hline \multirow[t]{2}{*}{ Nutlets } & Mostly smooth & Mostly papillous \\
\hline & $\begin{array}{l}2.5 \mathrm{~mm} \text { long } \\
(>1.8 \mathrm{~mm})\end{array}$ & $\begin{array}{l}\text { Mostly shorter than } \\
2 \mathrm{~mm}\end{array}$ \\
\hline $\begin{array}{l}\text { Beak of } \\
\text { nutlets }\end{array}$ & Distinct & $\begin{array}{l}\text { Indistinct, often curved } \\
\text { back }\end{array}$ \\
\hline Habitat & $\begin{array}{l}\text { Temporary gaps } \\
\text { within calcareous or } \\
\text { mildly brackish pools, } \\
\text { dune slacks, and } \\
\text { mesotrophic water } \\
\text { bodies }\end{array}$ & $\begin{array}{l}\text { Shorelines and long- } \\
\text { standing gaps in } \\
\text { weakly acidic pools } \\
\text { and oligotrophic lakes }\end{array}$ \\
\hline $\begin{array}{l}\text { Flowering } \\
\text { period }\end{array}$ & June-July (-August) & $\begin{array}{l}\text { June-October } \\
\text { (-November) }\end{array}$ \\
\hline $\begin{array}{l}\text { Breeding } \\
\text { system }\end{array}$ & Self-compatible & Self-incompatible \\
\hline $\begin{array}{l}\text { Inflorescence } \\
\text { growth }\end{array}$ & April-August & $\begin{array}{l}\text { Throughout the year } \\
\text { (inflorescence stolons) }\end{array}$ \\
\hline $\begin{array}{l}\text { Population } \\
\text { structure }\end{array}$ & $\begin{array}{l}\text { Scattered, detached } \\
\text { individuals in } \\
\text { relatively closed, tall- } \\
\text { herb vegetation }\end{array}$ & $\begin{array}{l}\text { Locally abundant, } \\
\text { networks of } \\
\text { vegetatively spreading } \\
\text { clones in open species- } \\
\text { poor asociations }\end{array}$ \\
\hline
\end{tabular}

with several other actively evolving taxa, however (e.g. Carex viridula, Ranunculus penicillatus, R. fluitans, etc.), it is possible that neither the "species" nor the "subspecies" concept wholly encompasses variability within Baldellia ranunculoides s.l.

\section{Synonyms}

\section{B. ranunculoides subsp. ranunculoides:}

Basionym: Alisma ranunculoides L., Sp. Pl.: 343 (1753);

Baldellia ranunculoides (L.) Parl., Nuov. Gen. Sp. Monocot.: 58 (1854);

Echinodorus ranunculoides (L.) Engelm. in P.F.A. Ascherson, Fl. Brandenburg 1: 651 (1864);

Baldellia ranunculoides subsp. ranunculoides À. Löve \& D. Löve, Bot. Not. 114: 49 (1961).

\section{B. ranunculoides subsp. repens:}

Basionym: Alisma repens Lam., Encycl. 2: 515 (1788); Alisma ranunculoides var. repens (Lam.) Duby, Bot. Gall.: 437 (1828);

Echinodorus ranunculoides var. repens (Lam.) Nyman, Consp. Fl. Eur.: 679 (1882);

Echinodorus ranunculoides forma repens Buchenau in H.G.A. Engler (ed.), Pflanzenr., IV, 15: 27 (1903); Echinodorus repens (Lam.) J. Kern \& Reichg., Ned. Kruidk. Arch. 57: 244 (1950);

Baldellia repens (Lam.) Ooststr. ex Lawalrée, Nouv. Fl. Belg. Luxemb. N. France etc.: 759 (1973);

Baldellia ranunculoides subsp. repens À. Löve \& D. Löve, Bot. Not. 114: 49 (1961).

\section{B. alpestris:}

Basionym: Alisma alpestre Coss., Bull. Soc. Bot. France 11: 333 (1864);

Echinodorus alpestris Micheli in A.L.P. de Candolle \& A.C.P. de Candolle (Eds.), Monogr. Phan. 3: 47 (1881);

Echinodorus ranunculoides "forma alpina" Buchenau in H.G.A. Engler (ed.), Pflanzenr., IV, 15: 27 (1903); Baldellia alpestris (Coss.) Laínz, Bol. Inst. Estud. Asturianos, Supl. Ci. 1: 35 (1960).

Vernacular names (unless otherwise indicated refer only to subsp. ranunculoides)

Danish: almindelig søpryd (subsp. repens: krybende søpryd); Dutch: stijve moerasweegbree (subsp. repens: kruipende moerasweegbree); English: lesser water-plantain (subsp. repens: creeping water-plantain); Flemish: stijve moerasweegbree; French: flûteau or baldellie fausse renoncule (subsp. repens: flûteau rampant); 
Gaelic (Irish): corrchopóg bheag; German: Igelschlauch; Italian: mestolaccia ranunculoide; Norwegian: soleigro; Polish: zabienica jaskrowata; Spanish: junquera; Swedish: flocksvalting (subsp. repens: revsvalting); Welsh: dyfr lyriad bychan (subsp. repens: dyfr lyriad ymlusgawl).

\section{Morphological and anatomical characterisation}

\section{Morphology}

Both subspecies are phenotypically very plastic aquatic herbs with a submerged or partially submerged rootstock (although individual plants can be wholly terrestrial in damp ground). They are also both usually perennial although, in rare cases, each can produce annual forms - for example in temporary pools or in the draw-down zone of large permanent water bodies. These "annual" plants, though, represent an atypical situation (failure to survive extended desiccation) and are not at all a genetic variant.

\section{Habit}

The habit of both subspecies is based, as in all the Alismataceae, on a common sympodial stem architecture but there are very important differences between the two taxa in their axis-development (Tomlinson, 1982). The vegetative axis of $B$. ranunculoides subsp. ranunculoides is a short erect corm, accommodating a dense cluster of broadly sheathing leaf bases, almost like a bulb (ca. $2 \mathrm{~cm}$ long and $1.5 \mathrm{~cm}$ broad). The corm of subsp. repens is smaller and very similar in shape (Fig. 1) but with its vegetative axis greatly extended through the elaboration of its terminal meristem. Such horizontal stems or "runners" in the Alismataceae have been described by Charlton (1973) as "pseudostolons" but are more accurately termed inflorescence stolons (Mühlberg, 2000). The flowers on these stems are partly or wholly replaced by vegetative meristems (Charlton, 1968; Tomlinson, 1982).

\section{Roots}

The roots of both subspecies are fibrous $(<0.5 \mathrm{~mm}$ diameter) with radial air-lacunae (Stant, 1963) and are usually very numerous (numbered in the hundreds), with horizontal branching to about $5-10 \mathrm{~cm}$ depth. Roothairs have not been observed (Tomlinson, 1982).

\section{Leaves}

The leaves of both subspecies are spirally arranged in a basal rosette (Fig. 1) and usually number between 5 and 35 per rosette. They are, however, exceptionally plastic in their morphology and anatomy, which effectively renders leaf characteristics useless for any taxonomic purpose. The petiole, for instance, can be anything from 0 (in young rosettes) to $50 \mathrm{~cm}$ long in submerged aquatic forms; either very narrow or broadly sheathing at the base. Leaf shapes range from the elongated, linear, ribbon-like, almost without a blade (in juvenile or submerged plants), through to petiolate forms with a narrowly lanceolate or nearly oval blade (in floating leaves) and anything from 1 to $9 \mathrm{~cm}$ long and 0.2 to $2.3 \mathrm{~cm}$ wide. The floating leaves in subsp. repens seem to be more articulated than in subsp. ranunculoides (Fig. 1:2g) but this is not a key character. The subject of heterophylly and leaf plasticity in Baldellia (and the Alismataceae in general) has been extensively studied and discussed by Glück $(1905,1906)$. Such phenotypic plasticity, which is characteristic of many aquatic plants and quite typical of the Alismataceae, probably has an adaptive function within their very dynamic and heterogeneous habitats (Charlton, 1973; Cronk and Fennessy, 2001; Dorken and Barrett, 2004).

\section{Leaf venation}

The blades of floating and emergent leaves have a parallel-reticulate venation with five major veins converging at the leaf apex and a network (anastomosis) of minor transverse veinlets, forming a closed reticulum. Only three of these major veins (including the median vein or false midrib) are, however, at all conspicuous in the fully expanded leaf (Fig. 1: 1b and 2b).

\section{Inflorescence}

The flowers of Baldellia spp. are of a thyrsus type (Mühlberg, 2000). Each plant usually produces only 1-2 (max. 5) inflorescences. The two subspecies represent two contrasted types of inflorescence orientation (Tomlinson, 1982; Mühlberg, 2000):

B. ranunculoides subsp. ranunculoides has an erect orthotropic inflorescence (not proliferating by vegetative meristems) with a long basal internode and 1-3 successive pseudowhorls, usually 2 (max. 4) pseudowhorls in total (Fig. 1: 1a). The inflorescence is terminal (Charlton, 1972). Each pseudowhorl has three bracts subtending solitary flowers with between (0-)6-15(-27) flowers per pseudowhorl - although only $1-2$ (max. 3) flowers are open on a single day. The whole inflorescence (and thus the whole plant) reaches max. $60 \mathrm{~cm}$ (usually $20-40 \mathrm{~cm}$ ). In unfavourable conditions the inflorescence can, however, be extremely small (in dwarf forms: 2-5 cm) (Fig. 1: 1h).

$B$. ranunculoides subsp. repens has a horizontal, stoloniferous plagiotropic inflorescence, with vegetative meristems in the axils of its bracts (Fig. 1: 2a). Typically, the inflorescence axis becomes an inflorescence stolon, with pseudowhorls of three scale leaves (bracts) and (0)2-4(-6) flowers at approximately $5-10 \mathrm{~cm}$ intervals (Charlton, 1968, 1973). Generally, 3-4 flowers will open on one plant in a single day. Subspecies repens has a 
determinate inflorescence with sympodial growth, and the terminal bud forms the terminal flower. The vegetative meristems at the nodes often develop rooted leafy rosettes (daughter plants), however, which thereby lead to a process of indefinite vegetative proliferation (Charlton, 1968, 1973; Tomlinson, 1982). The leaves of such young rosettes are always apetiolate and the nodes (when they produce roots) only form one daughter plant - although each of these can produce more than one subsequent pseudostolon (which gives the appearance of branching runners). Each rosette of subsp. repens produces usually $1-2$ (max. 5) runners (on average 1.2 runners, a mean of 106 rosettes, personal observation). Reports on pseudostolons longer than $50 \mathrm{~cm}$ are exceptional and would refer to such series of runners with small chains of plantlets along their length.

The existence of inflorescence stolons (runners) in subsp. repens is not unique in the Alismataceae. The trend toward the sterilisation of the inflorescence and transitions between the inflorescence and vegetative offshoots has been observed and described in many other genera in the Alismataceae and Helobiae (Charlton, 1973; Wilder, 1975; Mühlberg, 2000, 2004).

\section{Flowers}

The flowers are entomophilous and bisexual with pedicels $1.5-8(-10) \mathrm{cm}$ long. Each flower has 6 perianth elements (two alternate trimerous perianth pseudowhorls) with three relatively short green sepals and three much larger white or pale pink petals. The petals have faint purple veins going into glitzema with a shiny, yellow base (Vuille, 1988). All Baldellia species have six stamens with numerous free carpels arranged in a globose head (placing Baldellia very close to Luronium, Damasonium and Alisma (Charlton, 2004)). The differences, however, between flowering characters in the two subspecies are also of critical taxonomic significance (see also Table 2 and Fig. 1):

In $B$. ranunculoides subsp. ranunculoides the petals are white (rarely pink), small $\left(6.5 \times 7 \mathrm{~mm}^{2}\right)$ and usually not overlapping with sepals $2.5-3.6 \mathrm{~mm}$ long and flowers $(8-) 13-15(-18) \mathrm{mm}$ diameter with anthers $0.8-1.0 \mathrm{~mm}$ long (Fig. 1: 1c).

In $B$. ranunculoides subsp. repens the petals are generally pink (rarely completely white), large $\left(8.5 \times 10 \mathrm{~mm}^{2}\right)$ and usually overlapping with sepals 3-4.5 $\mathrm{mm}$ long and flowers $15-22 \mathrm{~mm}$ diameter, with anthers 1.1-1.5 mm long (Fig. 1: 2c).

\section{Fruits}

Baldellia spp. have globose aggregate fruit-heads, composed of numerous dry nutlets (achenes). The free achenes are arranged in successive cycles on the globular receptacle, ovoid, curved and strongly three-ribbed on the back with a double rib along their ventral sutures (Cook, 1990). They each have only one seed enclosed in the pericarp with a strongly curved (horseshoe-shaped) embryo (Tomlinson, 1982). The following fruit and achene characteristics are also important in differentiating the two subspecies (see also Table 2 and Fig. 1):

B. ranunculoides subsp. ranunculoides: The fruit-head is (4-)6-8 mm diameter and contains 25-45 nutlets (average 33 ). The nutlets are about $2.5 \mathrm{~mm}$ long, mostly smooth (without papillae) and with a distinct beak (Fig. 1: 1d).

B. ranunculoides subsp. repens: The fruit-head is 4-5 mm diameter with 15-20 nutlets (average 18). The nutlets are less than $2 \mathrm{~mm}$ long, mostly papillous (Figs. 1 and 2) with an indistinct, generally curved beak (Fig. 1: 2d).

Since the submerged juvenile leaves in different genera of the Alismataceae are ribbon-like and very similar, there is room for considerable misidentification. In the case of all Baldellia taxa, however, the fresh leaves and stems have a strong and distinctive smell of coriander (Romero et al., 2003; Grillas et al., 2004).

Baldellia ranunculoides s.l. can be distinguished from B. alpestris on morphological characters (Lawalrée, 1959; Casper and Krausch, 1980; Triest and Vuille, 1991; Franco and Afonso, 1994) although this may be a critical determination, especially in juvenile and submerged plants. Mature, well-developed B. alpestris is readily distinguished from $B$. ranunculoides s.l. through its smaller and more elliptical leaves with a blunt apex and its smaller petals and fewer nutlets.

By contrast, the separation between $B$. ranunculoides subsp. ranunculoides and subsp. repens is not always so easy (Triest and Vuille, 1991; Jones, 2006). The most important characteristics for field identification are (1) the general habit and methods of vegetative reproduction (subsp. ranunculoides is an erect plant without runners; subsp. repens is a creeping plant with runners, inflorescence rooting at the nodes); (2) the number of flowers per pseudowhorl (subsp. ranunculoides: mostly 10-20, subsp. repens: mostly only $2-3$ ); and (3) the surface of nutlets (subsp. ranunculoides: smooth, subsp. repens: papillous) (see Figs. 1 and 2). Table 2 summarises the most important morphological and ecological characteristics separating the two taxa but we should also note the existence of certain morphological gradients across European populations. For example, in Sardinia (Bocchieri and Iiriti, 2003) and in the South of France near Bezier (personal observations), there are populations of Baldellia growing in lakes over basaltic rocks with many of the characteristics of subsp. ranunculoides but exhibiting a phenotype similar to subsp. repens (with similar flowers and particularly elliptic leaf blades). Further studies on the morphologi- 


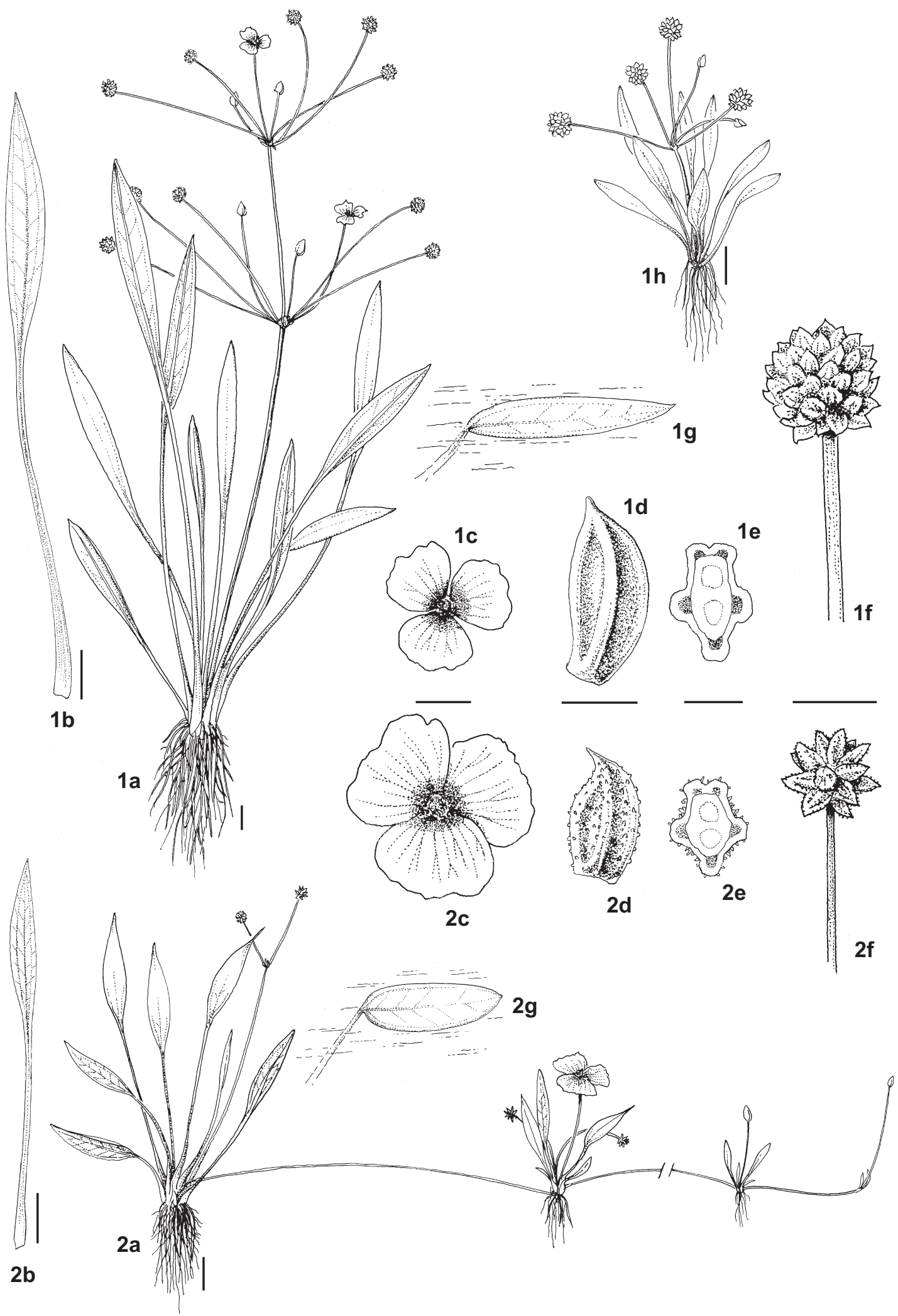

Fig. 1. Morphology of the subspecies: (1) B. ranunculoides subsp. ranunculoides, (2) subsp. repens; a - general habit, b - leaf (scale bar for a and b: $1 \mathrm{~cm}$ ), c - flower (scale bar: $0.5 \mathrm{~cm}$ ), d - nutlet (scale bar: $1 \mathrm{~mm}$ ), e - nutlet cross-section (scale bar: $0.5 \mathrm{~mm}$ ), $\mathrm{f}-$ fruithead (scale bar: $0.5 \mathrm{~cm}$ ), g-floating leaf; $1 \mathrm{~h}$ - terrestrial form of subsp. ranunculoides in nutrient-poor conditions (scale bar: $1 \mathrm{~cm}$ ). Plant material from Neuchâtel Lake, Switzerland (subsp. ranunculoides) and Banen Lake, Netherlands (subsp. repens). Drawn by S. Fogenhero 

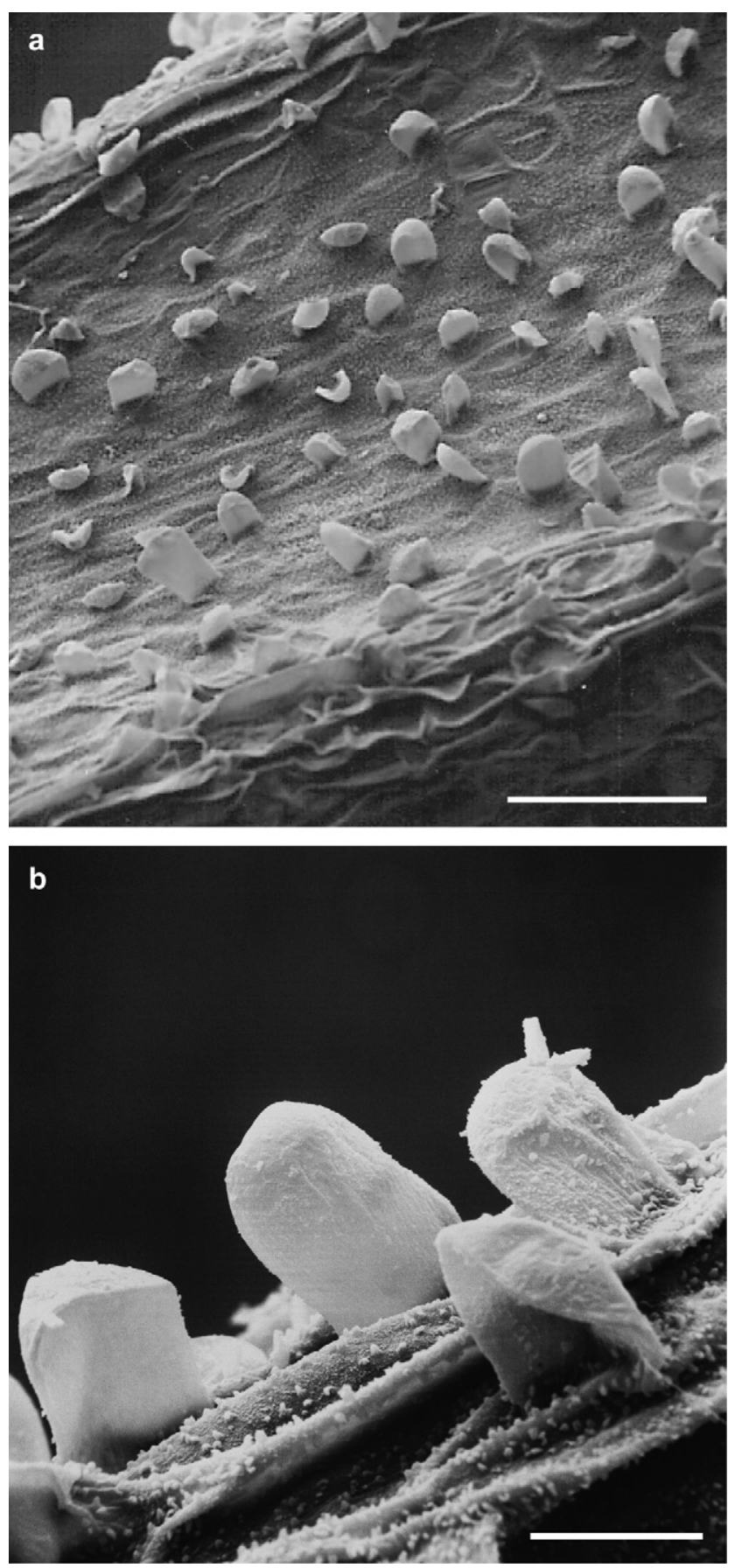

Fig. 2. Papillae on surface of $B$. ranunculoides subsp. repens nutlet. Scale bars - a: $0.1 \mathrm{~mm}$, b: $0.02 \mathrm{~mm}$. Plant material from the Botanic Garden Liège, Belgium.

cal and genetic gradients between these two subspecies are required.

\section{Anatomy}

The genus Baldellia - and other members of the notionally primitive Alismataceae - has long attracted the attention of anatomists. The most detailed accounts can be found in Stant (1963), Tomlinson (1982), Dahlgren et al. (1985), Wilson and Morrison (2000) as well as in the works of Glück (1905, 1906), Meyer (1932), Eckardt (1957) and Serbanescu-Jitariu (1973). There is also very useful information on anatomy, organogenesis and floral organisation in a series of publications on the Alismataceae published by W.A. Charlton at the University of Manchester, UK (for Baldellia the most important papers are Charlton, 1968, 1972, 1973, 2004). The most prominent feature of the Alismataceae, and thus of Baldellia, is the occurrence of schizogenous intercellular spaces (air-spaces, lacunae and diaphragms, see Fig. 3) in all parts of the plant, which are characteristic adaptations of this aquatic genus (Stant, 1963). The mechanical tissue is reduced (as it is in all water plants) and lignification is very much diminished. The vascular tissue is also reduced, although both types of vascular cells (xylem and phloem) are clearly distinguishable in the petioles of Baldellia spp.

The other notable anatomical characteristic is the presence of lactifers in aerial parts of the plant (Fig. 3), which exude a sticky white latex-type substance when fresh (Stant, 1963). These lactifers are associated with vascular bundles in the laminae of leaves, near the abaxial surface of petioles and in the leaf axis on the inner side of the hypodermis, near the outer strands of the cortical parenchyma (Stant, 1963). Meyer (1932) observed that subsp. repens has more lactifers than subsp. ranunculoides and that these are not so strongly associated with the vascular bundle.

The epidermis of Baldellia spp. has rectangular (polygonal) cells, elongated in the direction of their leaf

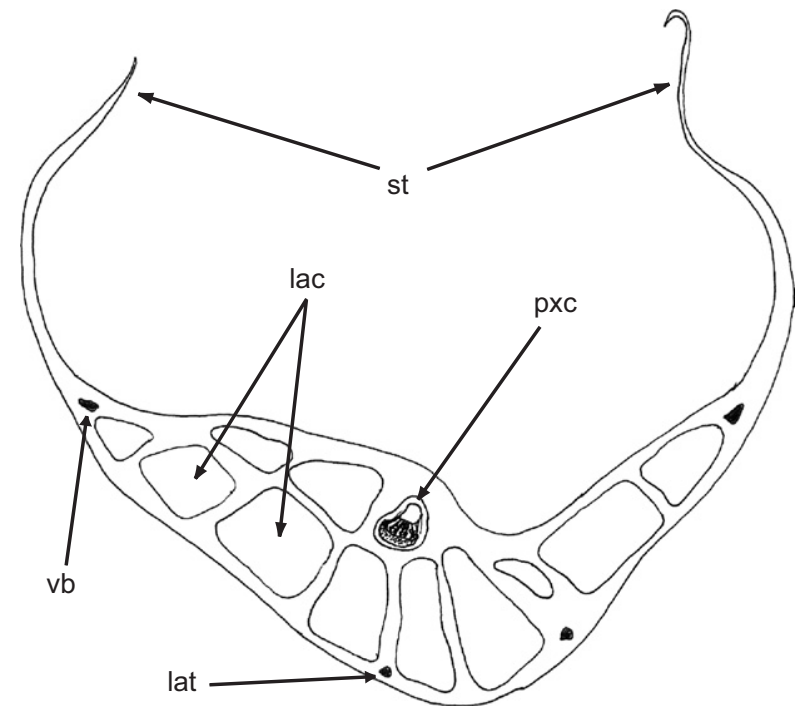

Fig. 3. B. ranunculoides subsp. ranunculoides. Transverse section of petiole base. Abbreviations: lac - lacunae, lat lactifer, pxc - protoxylem canal, st - stipulae, vb - vascular bundle. 
axis (Fig. 4) and this characteristic clearly differentiates them from Echinodorus spp. (which have distinctly sinuous or dentate epidermal cell walls). The stomata in Baldellia are mostly paracytic (with 2 subsidiary cells lying parallel to the guard cells) although they can occasionally be almost tetracytic (with four subsidiary cells) (Fig. 4). Stant (1963) reports that up to six subsidiary cells have been observed in subsp. ranunculoides, which could represent the most primitive arrangement observed within the monocotyledons. The stomata are more frequent on the adaxial surface (Meyer, 1932) and, on small and elongated leaves, are arranged parallel to the longitudinal axis. Calcium oxalate crystals have also been observed in the tissue of Baldellia.

Another characteristic of the Alismataceae and some other aquatic families is the presence of squamules (squamulae intravaginales) which are found in the axils of foliage and scale leaves (Tomlinson, 1982). This series of palisade-like scales is densely cytoplasmic and is
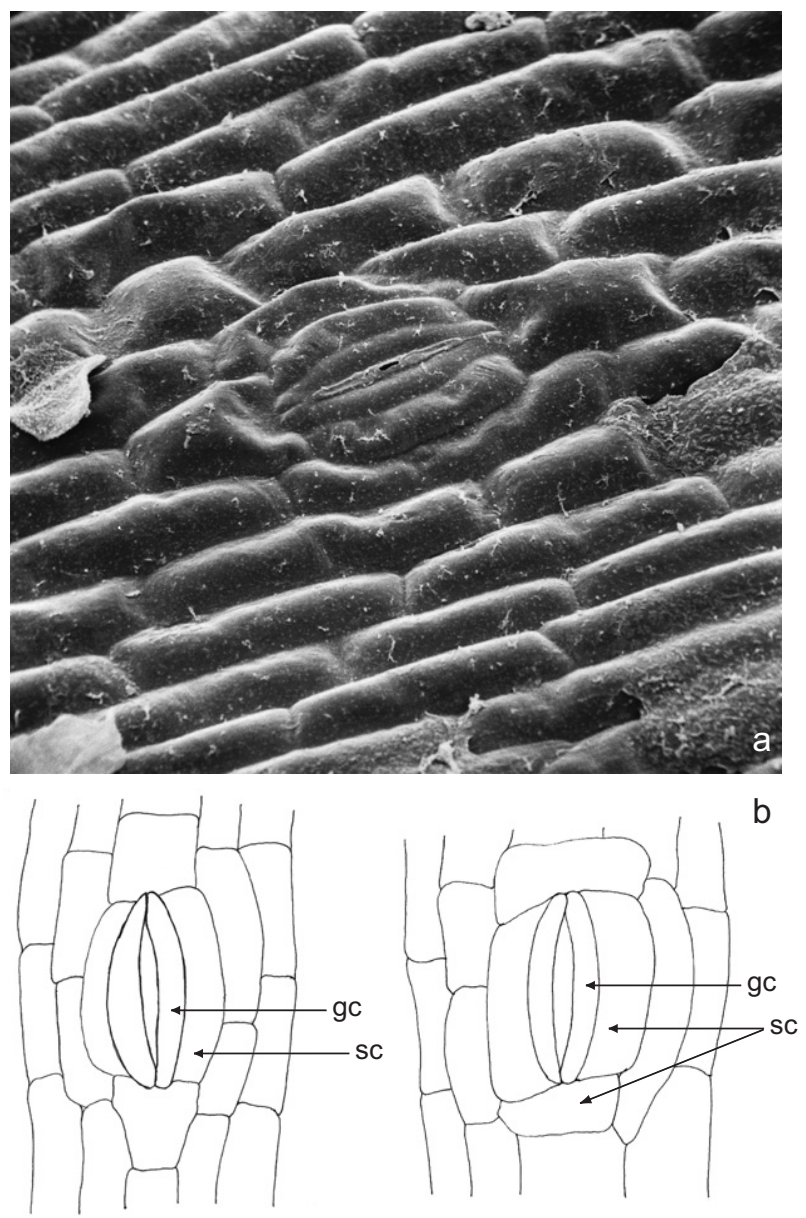

Fig. 4. B. ranunculoides subsp. ranunculoides - a: Stomata with guard and subsidiary cells; b: Stomata on abaxial epidermis with two possible arrangements of subsidiary cells. Abbreviations: gc - guard cell, sc - subsidiary cell. Plant material from the Botanic Garden Berlin-Dahlem, Germany. transformed during growth into a mucilaginous coating which protects the young leaves against direct water contact (Glück, 1906; Tomlinson, 1982).

The pollen grains of Baldellia spp. are of the Alismatype (Argue, 1974). They are spheroidal to polyhedral (Fig. 5), 18-32 $\mu \mathrm{m}$ in diameter, with 16-30 more or less circular pores, separated from each other by a distance slightly greater than their width. At $22-23 \mu \mathrm{m}$, the pollen grains in subsp. repens are slightly smaller than those of
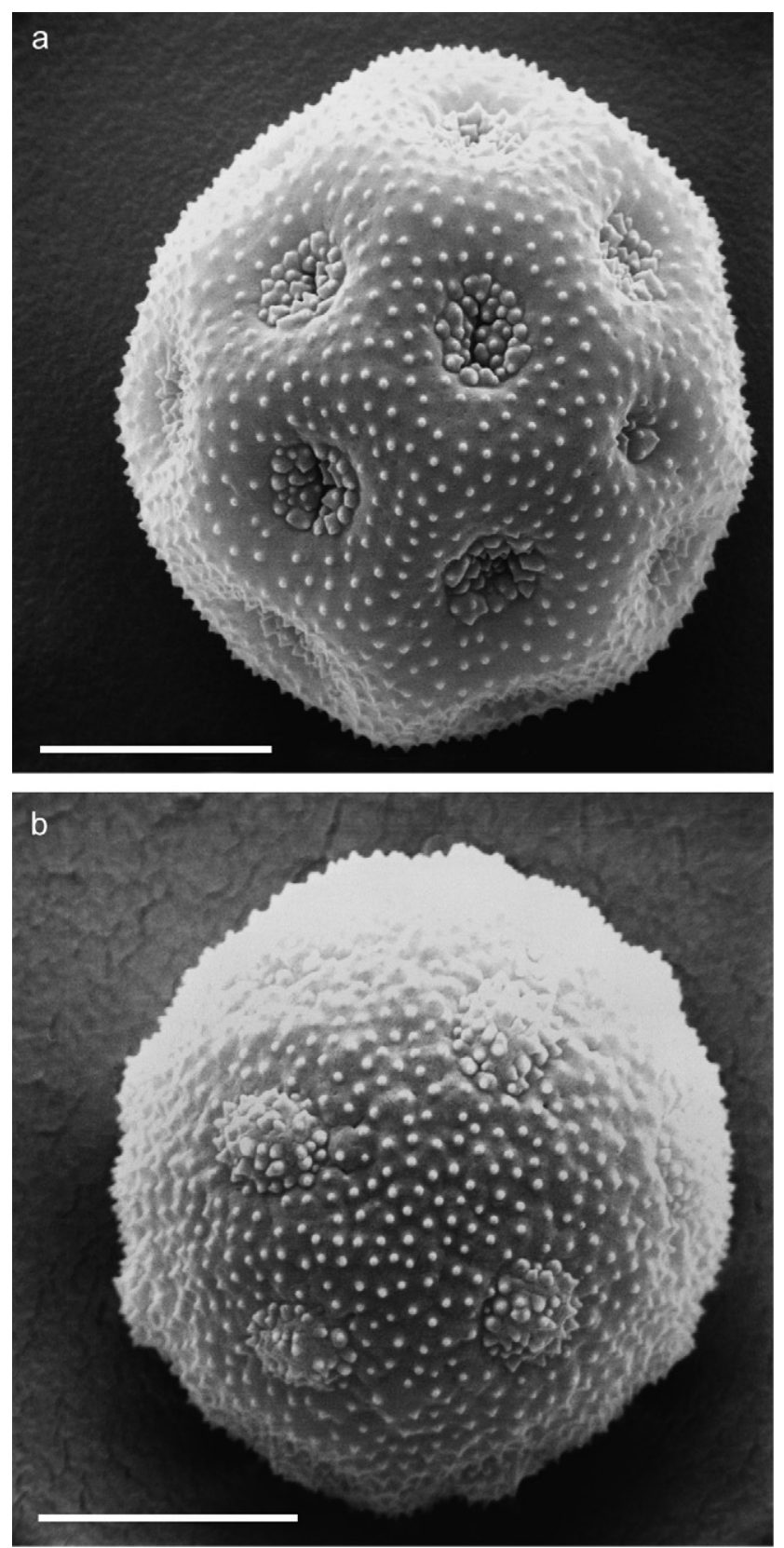

Fig. 5. Pollen grains of $B$. ranunculoides subsp. ranunculoides (a) and B. ranunculoides subsp. repens (b) (scale bar: $0.01 \mathrm{~mm}$ ). Plant material from the Botanic Garden Berlin-Dahlem, Germany (subsp. ranunculoides) and from the Botanic Garden Liège, Belgium (subsp. repens). 

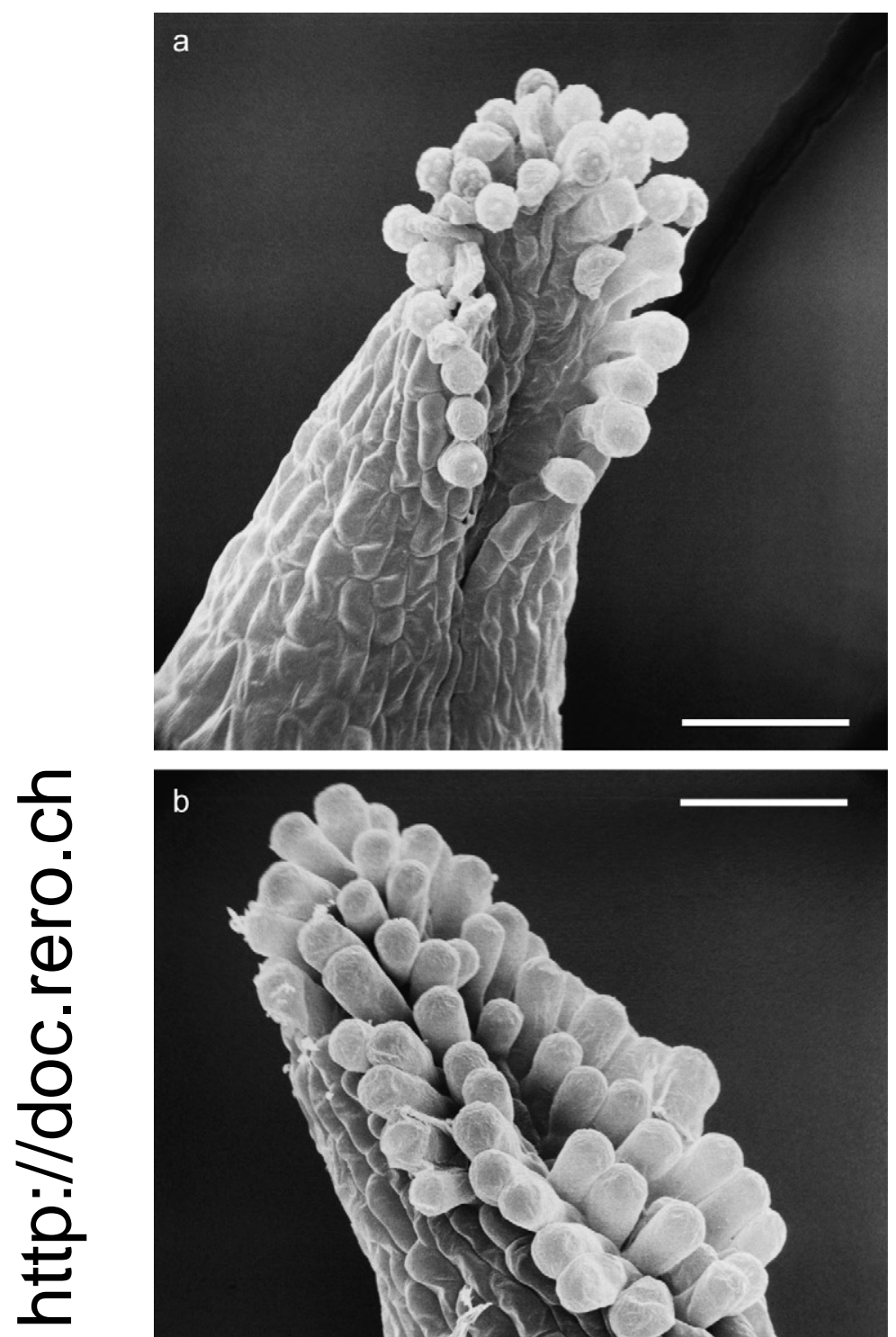

Fig. 6. Stigmata of B. ranunculoides subsp. ranunculoides (a) and $B$. ranunculoides subsp. repens (b) (scale bar: $0.2 \mathrm{~mm}$ ). Plant material from the botanic garden Berlin-Dahlem, Germany (subsp. ranunculoides) and from the botanic garden Liège, Belgium (subsp. repens).

subsp. ranunculoides (25-28 $\mu \mathrm{m}$ on average) and with a less prominent border or annulus (Punt and Reumer, 1981)

\section{Geographical distribution}

The published global distribution maps for $B$. ranunculoides s.l. are generally incomplete and most of

them overlook or blur the very notable east Mediterranean occurrences (Cook, 1983; Hulten and Fries, 1986; Meusel et al., 1992). The map presented by de Bolos and Vigo (2003) is a partial exception but it is very schematic. Fig. 7 provides a new and more detailed map of B. ranunculoides s.l., combining for the first time all known occurrences in Europe, North Africa and the Middle East. The complete list of global and regional maps available in the literature and the internet along with a range of other sources used for new distribution maps is shown in "Supplementary material".

The global distribution of B. ranunculoides s.l. fits the general pattern of an Atlantic/west Mediterranean species such as the very well-studied Ilex aquifolium (Walter and Straka, 1970) whereas subsp. repens seems to be more restricted to purely Atlantic/Oceanic conditions (Fig. 8 and detailed description below). The distribution of the Atlantic phytogeographical group is strongly influenced by climatic, edaphic and topographic conditions (Czeczott, 1926). According to Gorczynski (1922) the Atlantic climate area covers those regions of western and central Europe where the average annual temperature range is between 10 and $25^{\circ} \mathrm{C}$. For $B$. ranunculoides s.l. as well as for some other Atlantic species the mean annual isoamplitude (line connecting points with the same mean annual range of temperature) does not exceed $20^{\circ} \mathrm{C}$ (Czeczott, 1926). The northern and eastern distribution appears to follow the January $-2{ }^{\circ} \mathrm{C}$ isotherm - I. aquifolium, for instance, follows the $0{ }^{\circ} \mathrm{C}$ January isotherm (Jäger, 1968; Mai and Walther, 1988) - but more detailed studies are necessary here. Several occurrences in Sweden, Denmark, Poland and Germany appear to fall below this lower temperature threshold. Krausch (1985) speculated that edaphic factors could have a more significant influence in such border regions and this might also be the case in more eastern regions of the Mediterranean. Pietsch (1985), for example, notes that several water plants with an Atlantic distribution occur outside their more natural boundaries in anthropogenic habitats (e.g. in eastern Europe where coal mining has excavated, flooded ground, etc.). He concluded that, in eastern Europe, the $-1{ }^{\circ} \mathrm{C}$ January isotherm and the limits of relatively high rainfall represent the most important factors in the distribution boundary of Atlantic species. The southern distribution border in North Africa could be limited by the July isotherm of $26^{\circ} \mathrm{C}$. In the eastern Mediterranean Baldellia could, similarly, be limited by low levels of precipitation and summer drought. The exact climatic and edaphic preferences of both subspecies of $B$. ranunculoides s.l. need further study.

B. ranunculoides subsp. ranunculoides is an Atlantic/ west Mediterranean taxon (Jäger, 1968; Markgraf, 1981) growing mainly in coastal regions of western Europe and the Mediterranean (Hulten and Fries, 1986; Meusel et al., 1992; de Bolos and Vigo, 2003). The range of 
subsp. ranunculoides is given by the formula: $\mathrm{m}$-temp c14 EUR (Welk, 2001) with its centre of distribution in the Atlantic region. The species (in the wider sense) has been reliably reported from Albania, Algeria, the Azores, the Balearic Islands (Mallorca and Minorca), Belgium, the Canary Islands, Corsica, Croatia, Denmark, France, Germany, Greece, Ireland, Italy, Lebanon, Montenegro, Morocco, the Netherlands, Norway, Poland, Portugal, Sardinia, Sicily, Slovenia, Spain, Sweden, Switzerland, Syria, Tunisia, Turkey and the United Kingdom and more doubtfully from Baltic countries. The highest concentrations of subsp. ranunculoides appear to be found in Ireland (Preston and Croft, 2001) and in the Atlantic regions of France (Dupont, 1990). B. ranunculoides subsp. ranunculoides has been also introduced into North America (e.g. in Washington, USA: www.natureserve.org, www.itis.usda.gov) and New Zealand (Champion and Clayton, 2000) where it is treated as a potentially weedy species of aquatic habitats. In Germany this taxon only occurs in a very scattered distribution over the northern lowlands (not below $51^{\circ}$ latitude), although it used to be more widespread around North Rhine-Westphalia (Markgraf, 1981; Haeupler and Schönfelder, 1988). It was also described from numerous sites in Lower-Saxony and Schleswig-Holstein, where it is now strongly in decline (Haeupler and Schönfelder, 1988) and in Brandenburg (with Berlin), Saxony-Anhalt and Mecklemburg-Vorpommern, where the taxon was always very rare. These sites represent the eastern border of its global range and are now also at the edge of extinction (Benkert et al., 1998). In Poland there were only three well-described sites, around Szczecin and Wolin Island, where it is now probably extinct (Piotrowska, 1966a, b; Zajac and Zajac, 2001); the records from Warsaw and central Poland are very doubtful (Czeczott, 1926). In Switzerland subsp. ranunculoides was mainly found near the lakes of Geneva, Neuchâtel, Murten and Biel but there are now only four remaining populations, in the Lake of Neuchâtel (Käsermann and Moser, 1999).

In general, the Atlantic, west- and central European distribution of $B$. ranunculoides is quite well documented and the distribution map in Fig. 7 represents a very accurate picture of its distribution. In other parts of its range, however, the distribution is either not very well known or the records are very old and in need of revision. This is the case, for example, in the Baltic countries (Latvia, Lithuania and Estonia), where there are only very old references to Baldellia (Jundzill, 1791). Since there are neither herbarium specimens nor any reports in the more recent literature, this taxon is no longer included in the latest Floras and Red Lists for the Baltic countries. The distribution data for North Africa are also approximate, since the existing literature often gives only general information on regional distribution and/or selected study sites (Battandier and Trabut, 1895,
1905; Bonnet and Barratte, 1896; Jahandiez and Maire, 1931; Maire, 1952; Braun-Blanquet, 1953; Cuénod et al., 1954; Pottier-Alapetite, 1958; Quezel and Santa, 1962). The best descriptions of subsp. ranunculoides and its habitats in North Africa come from the studies of Braun-Blanquet (1953) in Kroumirie and from PottierAlapetite (1958) in Sedjenane region, both in Tunisia. These regions both have a relatively high rainfall (c. $1700 \mathrm{~mm}$ per year) with average air humidity oscillating between $85 \%$ in January and $60 \%$ in August and with a mean August temperature (the warmest month) below $25^{\circ} \mathrm{C}$. Braun-Blanquet (1953) suggested that this isolated occurrence could be a result of ancient land connections with Sicily (the Berbérie-Sicily or ItaloAfrican bridge) although Pottier-Alapetite (1958) proposed that dispersal from the Iberian peninsula to Morocco and further east via a "pont betico-rifain" should also be taken into consideration. The extremely isolated and easternmost populations of subsp. ranunculoides from Lebanon (Beirut, probably naturalised) and Syria (Outaya), described by Mouterde (1966) and those mentioned by Cook (1983) from Libya need further study. In the most western parts of its range, the very isolated population of subsp. ranunculoides from Lagoa de Achada in Terceira (Azores) is also probably naturalised (Schäfer, 2002, 2003, 2005). The status of subsp. ranunculoides in the Canary Islands is not clear. There are herbarium specimens from the archipelago (in the Herbarium of the Botanical Garden of Geneva, Switzerland) but without an exact locality. The recent Flora of the Canary Islands (Hohenester and Welss, 1993) does include Baldellia but also casts doubt over its current status there.

In view of the range extensions of subsp. ranunculoides into the east Mediterranean region (Fig. 7) Dupont, in his exhaustive work on the Atlantic flora of Europe (Dupont, 1962), proposed that this species has a Mediterranean-Atlantic rather than an AtlanticMediterranean distribution (see also Bournerias and Wattez, 1990). He therefore placed it in the category of "partially Atlantic species". An examination of the new distribution map (Fig. 7), however, along with the available literature, clearly demonstrates that subsp. ranunculoides is much rarer in the Mediterranean than in Atlantic western Europe. The taxon is relatively widespread in the west Mediterranean region but, by contrast, only exists in a few, very isolated and generally small populations in the eastern Mediterranean (sensu Rikli, 1943) - and perhaps only at higher altitudes or in regions with more Oceanic/Atlantic conditions: in Croatia, Montenegro, Albania, Greece, Turkey, Syria, Lebanon and Libya (Mouterde, 1966; Cook, 1983; Davis, 1984; Vangjeli et al., 1995; Vangjeli, 2000; Bazos and Yannitsaros, 2001; Hadziablahovič, 2005). This probably reflects a fundamental habitat scarcity for Baldellia and the unfavourable climatic conditions of the 


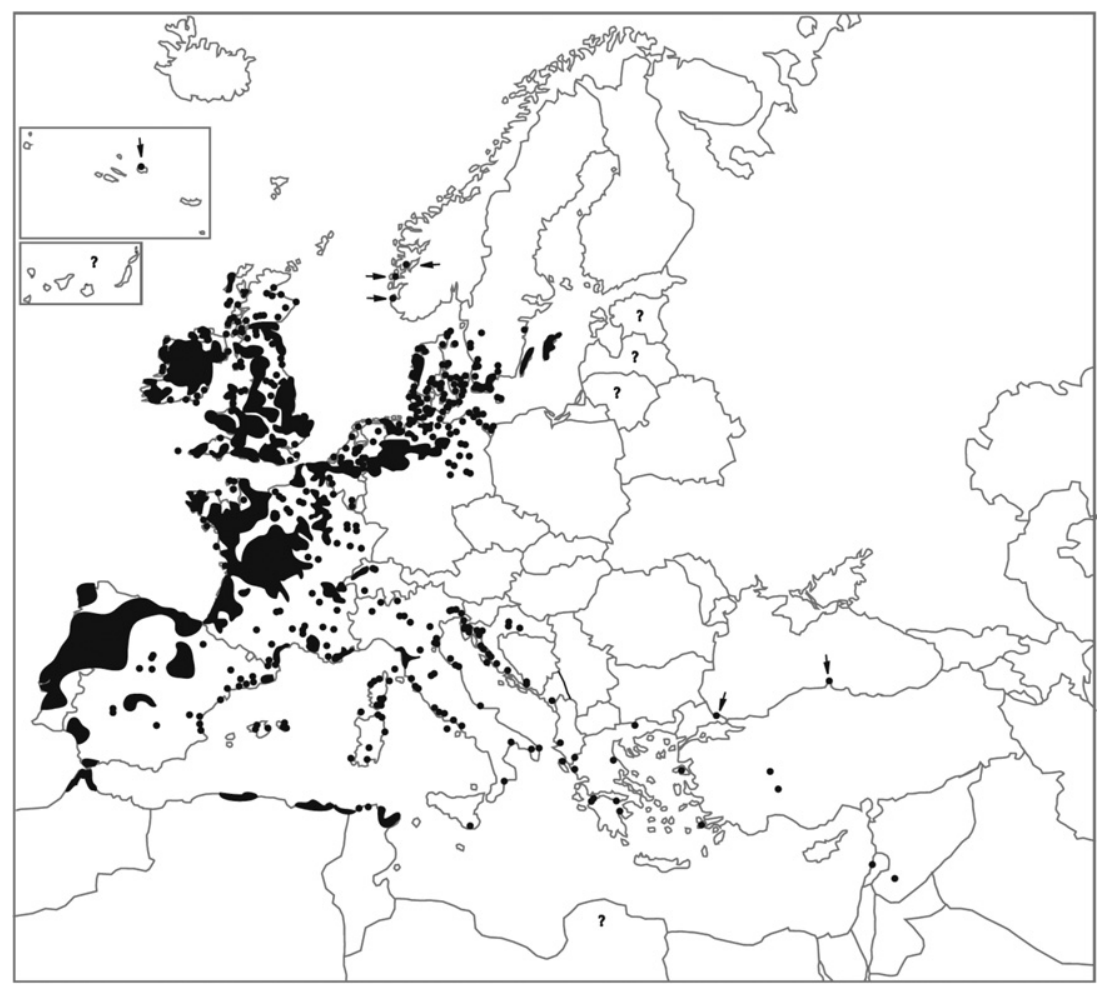

Fig. 7. Global distribution of Baldellia ranunculoides s.l. (subsp. ranunculoides and subsp. repens together, for references see "Supplementary material"). Question marks: exact location of occurrences in Baltic coutries, on the Canary Islands and in Libya unknown.

eastern Mediterranean (for more explanation see also "Altitudinal range").

The exact distribution of $B$. ranunculoides subsp. repens is unknown and its range formula remains undefined. The taxon is, however, mentioned in many national and local Floras for western Europe and the west Mediterranean. Fig. 8 provides a preliminary schematic distribution of subsp. repens, taken from all the available sources (see "Supplementary material"). The map indicates that this taxon is almost sympatric with subsp. ranunculoides in northwest Europe, although it occupies different habitats (see "Habitats characteristics"). It has, for instance, been reliably described from almost all the countries of western and northern Europe: i.e. from the UK and Ireland (Preston and Croft, 2001); from Portugal, Spain, France, Belgium, Holland and Germany (Casper and Krausch, 1980); and from Denmark, Sweden and Norway (in Norway all known occurrences of Baldellia are this taxon) (Lindblad and Ståhl, 1990). B. ranunculoides subsp. repens appears to be very rare in central Europe and its main centre of distribution (where it may be more frequent than subsp. ranunculoides, with numerous local occurrences) seems to be in west and central France (e.g. Sologne, Forêt d'Orléans), Belgium and the Netherlands (e.g. Limburg). The only reliable accounts of subsp. repens from Germany are from Rügen
(Schmale Heide; Ascherson and Graebner, 1913), from Schleswig-Holstein (Casper and Krausch, 1980) and from the northern part of Saxony-Anhalt (Schmeil and Fitschen, 1993) but there are several records from close to the German borders with the Benelux countries and Scandinavia so new discoveries are still possible. $B$. ranunculoides subsp. repens is not present in Switzerland although there is one very old and doubtful indication in the literature (unsupported, however, by any herbarium specimen), from Port Conty, Saint-Aubin (Lac de Neuchâtel) (Graber, 1924).

To the south of this range subsp. repens is also reported from several regions in the western Mediterranean: in France (including the Massif Centrale), Italy (Lawalrée, 1959), Istria (Croatia) (Casper and Krausch, 1980) as well as in western North Africa: Morocco, Algeria (Maire, 1952; Casper and Krausch, 1980) and Tunisia (three populations discovered in 2007 next to Ain Draham, Tabarka and Jehel Chitane, personal observation). The material used for the first scientific description of subsp. repens was actually collected from northeast Algeria. There are also further records of this taxon from the Balearic Islands, Mallorca and Minorca (Barcelo, 1977) but not from Corsica and Sardinia (Jeanmonod and Burdet, 1989). It is not described - and it is almost certainly absent from the southeastern Mediterranean, e.g. in Albania, Greece, Turkey, Lebanon 


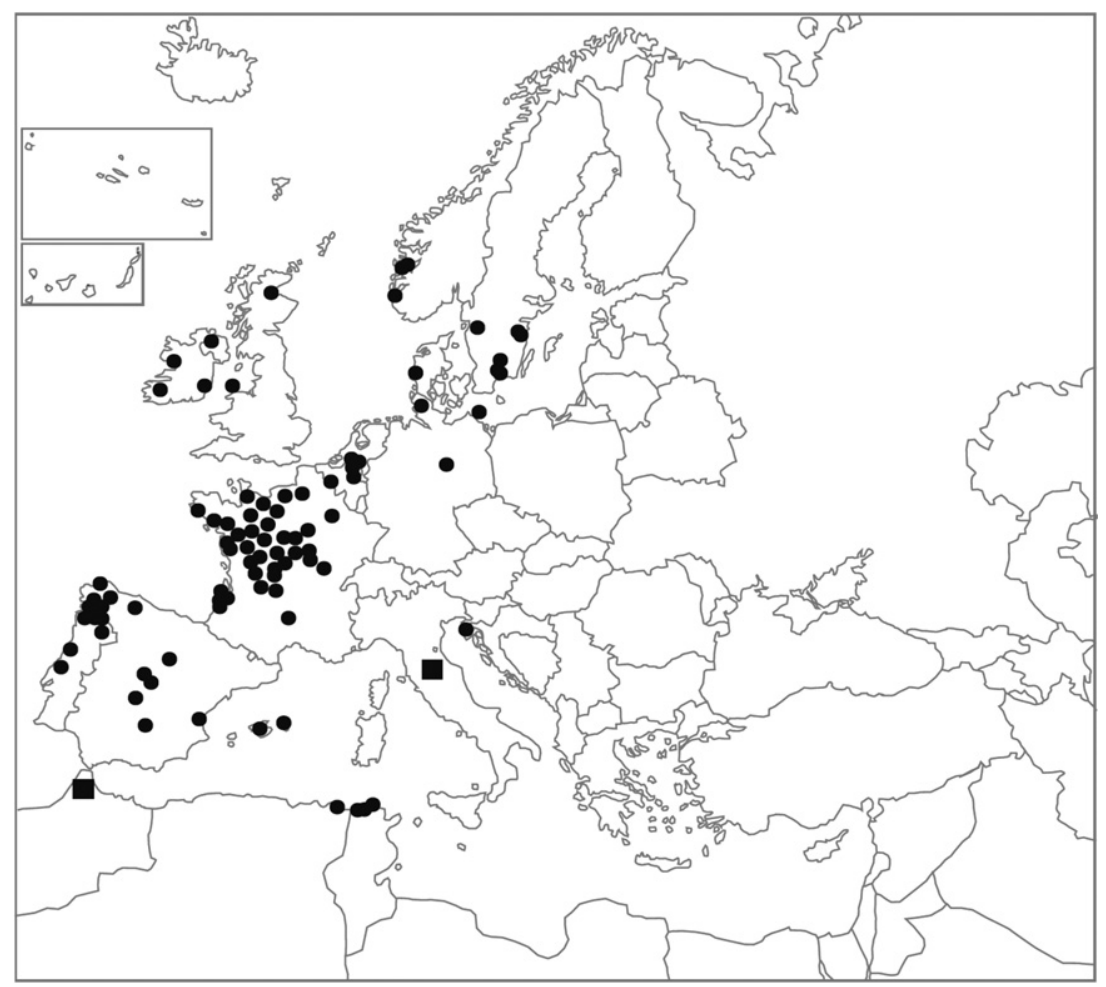

Fig. 8. Schematic distribution map of B. ranunculoides subsp. repens. Circles: exact occurrences reported in the literature. Squares: geographically inexact literature indications at country/region level (for references see "Supplementary material").

and Syria (Davis, 1984; Vangjeli et al., 1995), where there have only so far been records of subsp. ranunculoides. Thus, it seems that subsp. repens is restricted to the more Atlantic regions of northwest Europe and to some fairly isolated sites in the western and north Mediterranean.

\section{Altitudinal range}

B. ranunculoides subsp. ranunculoides is a lowland taxon in central and northern Europe, ascending (rarely) to $320 \mathrm{~m}$ a.s.l. in Great Britain (west of Libanus, Preston and Croft, 2001) and $432 \mathrm{~m}$ a.s.1. in Switzerland (Käsermann and Moser, 1999). In the southern Alps (Laragnais, France), however, it has been observed at an altitude of $630 \mathrm{~m}$ a.s.1. (Chas, 1994) and in the Mediterranean region at still higher altitudes. In Cantabria (Spain) for instance, subsp. ranunculoides, can grow up to $1060 \mathrm{~m}$ a.s.l. (Aedo et al., 2001) and in Tunisia (Kroumirie) at $780 \mathrm{~m}$ a.s.1. (Braun-Blanquet, 1953). In the Atlas Mountains (Morocco) this taxon has also been observed at up to $1600 \mathrm{~m}$ a.s.l., and in Turkey it was described from Beysehir Lake at $1115 \mathrm{~m}$ a.s.1. (Davis, 1984). One of the highest sites has been found recently in Greece at Drakolimni Lake at about $2000 \mathrm{~m}$ a.s.l. (Thomas Raus, pers. comm.). This phenomenon of many Atlantic species growing at higher altitudes towards the southern limits of their range was first described by Czeczott (1926). The mountainous regions of the Mediterranean probably offer Baldellia taxa more suitable conditions (e.g. higher precipitation and humidity, shorter drought period, etc.) and represent a kind of refugium in regions with very dry and hot summers. The altitudinal range of subsp. repens is not so well documented but this subspecies appears to prefer lowland sites, since the majority of confirmed records are from the coastal Atlantic region (Lawalrée, 1959; Casper and Krausch, 1980). It is possible, however, that it could also ascend to higher altitudes in the Mediterranean or in the Massif Central, for instance, where there are also credible records (Lawalrée, 1959).

\section{Fossil records of Baldellia spp. and their possible migration-routes}

Fossil remnants of the Alismataceae have mainly been found in the Miocene and Pliocene deposits of Europe and Siberia and these remains are reviewed by Daghlian (1981) and Erwin and Stockey (1989). These data suggest that the family had its origin in the Old World and only later spread to the New World. The majority of extant species and genera are still found in the Old World and Echinodorus is the only genus of the Alismataceae exclusive to the New World. Sagittaria 
and, to lesser extent Alisma, are well represented in both domains (Cook, 1990) and in the genus Damasonium we can observe a remarkable disjunction between existing species, with one representative in North America (D. californicum) and the other, D. alisma, in Europe (Vuille, 1987). This distribution could be an example of long-distance dispersal and subsequent evolution but there is also some evidence that other Old World genera spread to the New World and then later become extinct. The genus Caldesia, for example, which today grows only in Europe, South Asia and Australia, has been found (as C. brandoniana) in Miocene deposits c. 20 m.yr old from Vermont (USA) (Smiley and Rember, 1985). This corresponds with the existence of NorthAtlantic and Bering bridges, which could serve as migration routes.

Various palaeobotanists (e.g. Haggard and Tiffney, 1997) have separated out the fossil seeds of Baldellia spp. from those of other Alismataceae and Weber (1893) was the first to provide a description of fossil $B$. ranunculoides s.l., from Klinge, close to Cottbus (east Germany), dated from the Riss-Würm interglacial period. More recently, Mai and Walther (1988) reported fossil seeds of $B$. ranunculoides s.l. in Pliocene deposits (2.5-3.4 m.yr before present) from nearby Thüringen, accompanied by several other European aquatics: e.g. Carex riparia, Cyperus fuscus, Lemna trisulca, Myriophyllum spicatum, Schoenoplectus lacustris, Hippuris vulgaris and Lycopus europaeus, indicating an earlier mesotrophic/eutrophic habitat. Today, in eastern Germany, B. ranunculoides s.l. is an extreme rarity. Mai and Walther (1988) also reported the discovery of another enigmatic fossil Baldellia species, B. gailensis (described by Reid in 1923 from Pliocene deposits of Pont-de-Gail, France), although they speculate that these seeds could equally belong to Echinodorus tenellus (which is now only found in South and North America).

Cook (1983) classified B. ranunculoides s.l. as a member of the very small group of palaeoendemic aquatic plants of Europe and Mediterranean and Rich and Nicholls-Vuille (2001) suggest that the Iberian peninsula represents a possible centre of origins and diversification for the genus (as for some other closely related genera in the Alismataceae, e.g. Damasonium sp.). This is also supported by earlier palaeogeographic research (Braun-Blanquet, 1923), which identifies Iberia as the likely refuge for the Atlantic element, prior to its expansion into southern Europe and the Mediterranean during the early and mid-Quaternary period. The subsequent extension of these species' range into Scandinavia and the east Baltic region most probably took place during the Littorina Sea period (7500-7000 yr.b.p.) (Czeczott, 1926), after the final glaciation - and especially during more favourable climatic conditions in the Atlantic period (Czeczott, 1926; Szafer, 1959). Czeczott (1926) and Braun-Blan- quet (1923) also concluded that Atlantic species (e.g. $B$. ranunculoides s.1.) have passed through several phases of range-expansion and diminution during the last millennia and that in some periods they were much more widely distributed in Europe than it is currently the case. Some of the more highly isolated populations in the Mediterranean region could thus represent fragments of more ancient, wetter and colder climatic conditions and could potentially, be relict populations from former, more Atlantic periods. On the other hand, it is also recognised that aquatic plants have a considerable capacity for long-distance dispersal (Les et al., 2003) and some isolated populations could equally be the result of more recent movement via birds.

\section{Habitats characteristics}

\section{Habitat}

All species of Baldellia are thought to be very weak competitors and can only grow in habitats within a discrete range of natural and/or anthropogenic disturbance linked to water and nutrient levels, stock trampling, fish pond exploitation, etc. (Cook, 1983; Preston and Croft, 2001). They tend, therefore, to disappear from these pioneer habitats when more robust species take over (Casper and Krausch, 1980; Markgraf, 1981). Jones (2006) suggests that subsp. repens mainly grows in long-standing gaps in weakly acidic or oligotrophic water-bodies whereas subsp. ranunculoides, by contrast, prefers mesotrophic habitats and temporary gaps within calcareous or mildly brackish pools (see Table 2). Significantly, perhaps, populations of an intermediate - and probably hybrid - form are reported from sites where these two habitats intersect i.e. coastal heathland pools with disturbed peaty habitats, overlying calcareous clays (Jones, 2006).

B. ranunculoides subsp. ranunculoides typically occurs along the edge of shallow meso-oligotrophic lakes, ponds, reservoirs and pools, on the shorelines of slow streams, in marshes, fens, brackish dune pools and temporary slacks (Casper and Krausch, 1980; Bournerias and Wattez, 1990; Noest, 1991; Preston and Croft, 2001; Jones, 2006). It can also be found in more anthropogenic or disturbed habitats such as ditches, canals, flooded quarries, man-made dune wetlands, abandoned peat-drains and cuttings, fish ponds, and temporary flooded fields (Casper and Krausch, 1980; Charpin and Salanon, 1985; Krausch, 1985; Palmer and Roy, 2001; Preston and Croft, 2001; Denys, 2003; Cooper et al., 2005). More occasionally, subsp. ranunculoides is present in relatively eutrophic conditions, caused by animals (guanotrophy) (Schoof-van Pelt, 1973) and in Portugal it has been described as a 
weed-species of rice fields (Moreira et al., 1999). There are also records from wet depressions in coastal grasslands grazed by horses and cattle (Loucougaray et al., 2004) or by sheep (Dimopoulos et al., 2005) and in northwest Spain the taxon grows in "annual wetlands" or small, temporary shallow lakes at $750-1100 \mathrm{~m}$ altitude, with strong seasonal water-depth variation (Fernandez-Alaez C., 1999). Raabe and van de Weyer (1998) reported subsp. ranunculoides from North RhineWestphalia (Germany) in restored or newly created "species conservation water bodies" ("Artenschutzgewässer"), with artificially scraped and flooded surfaces.

The subspecies is also usually found in at least slightly basic (or hard-water) habitats but it can also occur (although rarely) in softwater and acidic sites. The basic habitats receive enrichment from different sources: e.g. from calcareous or ultrabasic rocks, from dune sand, or from chalk or limestone (Preston and Croft, 2001; Murphy, 2002). In Sardinia (Bocchieri and Iiriti, 2003) and in the south of France near Bezier (personal observation) it grows in lakes over basaltic rocks. $B$. ranunculoides subsp. ranunculoides can grow in brackish waters with salinity values ranging from 150 to $1850 \mu \mathrm{S} /$ $\mathrm{cm}$ (by comparison: Cladium mariscus occurs in sites with up to $15,500 \mu \mathrm{S} / \mathrm{cm}$ and Iris pseudacorus up to $10,400 \mu \mathrm{S} / \mathrm{cm}$ ) (Fullana Montoro, 2001). The subspecies tolerates a wide range of mainly inorganic substrates (e.g. sand, clay, calcareous marl) but can also grow on organic peats, mud, etc. (Casper and Krausch, 1980; Cook, 1983; Preston and Croft, 2001). B. ranunculoides subsp. ranunculoides, like some other aquatic plants (e.g. Littorella uniflora, Lobelia dortmana and Luronium natans) prefers substrates with nitrates $\left(\mathrm{NO}_{3}^{-}\right)$rather than with ammonium ions $\left(\mathrm{NH}_{4}^{+}\right)$(Walstad, 1999; Smolders et al., 2002). The genus as a whole could therefore have an advantage over species that use ammonium as a nitrogen source (that is in sediments with high redox potential) (Smolders et al., 2002).

The taxon has been observed in Kalodiki Fen complex, Greece, in alkaline water with a low hardness value but high phosphorus, nitrogen and iron content. It is restricted there, however, to the drier and more nitrogen-poor areas of the fen, with a lower $\mathrm{pH}$ level (Dimopoulos et al., 2005). In Corsica and in some other Mediterranean regions subsp. ranunculoides grows in oligotrophic pools, which are flooded in winter and spring and very thoroughly dried-out in summer. The substrates here are thin, rock soils (of granite, schist or rhyolite) or fine sediments with a very low organic matter content (i.e. sand, silt and clay). Most of these sites are on siliceous rock (with the exception of a pool at Padulu, near Bonifacio, which lies on calcareous substrates; Gamisans, 1991, 1999; Grillas et al., 2004). In Tuscany (Italy) Maremmani et al. (2003) observed subsp. ranunculoides in more basic dune slacks ( $\mathrm{pH} 8.7)$, with substrates consisting of sand (93\%), silt (1.4\%) and clay $(5.6 \%)$. In Tunisia B. ranunculoides was reported from small fens and peatland with an exceptionally low $\mathrm{pH}$, between 5.3 and 5.8 (Braun-Blanquet, 1953) but the possibility that this could have been subsp. repens might explain this otherwise very atypical habitat.

B. ranunculoides subsp. repens: Dupont $(1990,2001)$ has observed that subsp. repens can be common (or even locally dominant) in some regions or Departements of France where subsp. ranunculoides is rare or absent, e.g. Loire-Atlantique and the Vendée and this seems also be true in Burgundy (Bugnon et al., 1993) and Sologne (personal observation). This spatial exclusion could be explained by differential habitat and substrate preferences (Table 2). Vuille (1988), referring to Roelofs' study of softwater macrophyte habitats in the Netherlands (Roelofs, 1983; Roelofs et al., 1984), concluded that there are some ecological factors which seem to separate the two taxa; for instance, subsp. ranunculoides grows mostly on calcareous sediments with lime- $\left(\mathrm{CaCO}_{3}\right)$-type water, whilst subsp. repens is mostly found on noncalcareous sediments with gypsum- $\left(\mathrm{CaSO}_{4}\right)$-type water. Roelof's studies were mainly focused, however, on Littorella uniflora and there was only one instance of subsp. repens in the analyses. B. ranunculoides subsp. ranunculoides was present in nine study sites but never with cover exceeding 5\%. So Vuille's inference and conclusions should, perhaps, be taken with some caution. There is, however, other evidence that subsp. repens is primarily restricted to soft-water habitats (poor in calcium), with low nutrients and availability of carbon dioxide $\left(\mathrm{CO}_{2}\right)$ (Arts and den Hartog, 1990). In Atlantic and Subatlantic regions and in central and western Europe these habitats occur over acid sands (e.g. Holocene or Pleistocene loess and fluvioglacial deposits) and in bogs (Schoof-van Pelt, 1973; Brouwer et al., 1999; Brouwer and Roelofs, 2001; Roelofs, 2002). Where these water bodies have been eutrophicated or subject to alkaline/sulphate-rich water for a prolonged period the populations of subsp. repens have almost completely disappeared. Casper and Krausch (1980) and Brouwer and Roelofs (2001) also note that subsp. repens prefers shallower waters to subsp. ranunculoides (the latter taxon can grow down to $1.2 \mathrm{~m}$ ) and also grows on less steeply sloping shores. These habitat conditions both favour a vegetatively spreading plant, able to exploit newly emergent bare ground. Schoof-van Pelt (1973) observed subsp. repens on compact soils consisting of sand covered with a thin layer of mud or organic matter (from flood marks) and on loamy sand.

\section{Communities}

B. ranunculoides subsp. ranunculoides: In central Europe subsp. ranunculoides is a characteristic species of the class Littorelletea uniflorae Br.-Bl. et Tx. 1943, 
and it can be found in all the principle alliances (Casper and Krausch, 1980; Markgraf, 1981; Pott, 1995; Schubert et al., 1995). The main one of these is the Hydrocotylo-Baldellion Tx. et Dierssen 1972 (an alliance with strong Atlantic affinities, on mostly organic soils in more coastal regions of northwest Europe and also eastern Germany). B. ranunculoides subsp. ranunculoides is also described as a characteristic species of the Samolo-Baldellion Schaminée et Westh. 1990 (Krausch, 1985; Pott, 1995; Schubert et al., 1995; Petersen, 2000).

The most extensive populations of subsp. ranunculoides have, however, been observed in two further Littorelletean alliances: the Eleocharition multicaulis Vanden Berghen 1969 and the Eleocharition acicularis Pietsch 1967 (Tüxen, 1937; Schoof-van Pelt, 1973; Rodwell et al., 1991; Passarge, 1999; Sandsten, 2003). It grows in these alliances almost exclusively with Eleocharis spp. on very gently sloping lake and pond shores. The most comprehensive account of Littorelletean communities in western Europe - and communities with Baldellia spp. - can be found in Schoof-van Pelt (1973).

The commonest Littorelletean species accompanying subsp. ranunculoides in central, north and northwest Europe are: Samolus valerandi, Littorella uniflora, Eleocharis multicaulis, E. acicularis, Ranunculus ololeucos, Apium inundatum, Hydrocotyle vulgaris, Hypericum elodes, Juncus bulbosus, Anagallis tenella and Ranunculus flammula (Schoof-van Pelt, 1973; Casper and Krausch, 1980; Markgraf, 1981; Lindblad and Ståhl, 1989; Pott, 1995). Several further species appear with subsp. ranunculoides in the Littorelletean communities of Spain and Portugal, e.g. Anagallis crassifolia, Isoetes azorica, Isolepis fluitans, Juncus heterophyllus, Myosotis lusitanica, Rhynchospora rugosa, Elatine hexandra (Velayos et al., 1989; Rivas-Martinez et al., 2002).

Besides these Littorelletean communities, subsp. ranunculoides is often given as a typical element of socalled isoetid vegetation. Murphy (2002) described two main types of these communities with subsp. ranunculoides as a constant: (1) dwarf annual amphibious swards of temporally disturbed shorelines in lakes and reservoirs or exposed sediments and mud-flats in smaller temporary water bodies, (2) perennial isoetid lawns found in amphibious to deep-water sites. Furthermore, subsp. ranunculoides has been found and described in a broad spectrum of aquatic and semi-aquatic communities from the Phragmitetean and Isoeto-Nanojuncetean classes, occasionally even as a co-dominant (Casper and Krausch, 1980; Wheeler, 1980; Pott, 1995; Schubert et al., 1995). Petersen (2000), studying island dune habitats along the southern part of the North Sea, described an "association with Echinodorus ranunculoides", with numerous species of the Potametean and Charetean classes. He also reported subsp. ranunculoides from several Isoëto-Nanojuncean communities: e.g. the
Cypero fusci-Limoselletum aquaticae (Oberd. 1957) Korneck 1960 with Limosella aquatica and Cyperus fuscus and from the Cicendietum filiformis Allorge 1922. There are further accounts of subsp. ranunculoides as an important element of the Cypero fusci-Samoletum Müller-Stoll \& Pietsch ex Pietsch 1973 (Isoëto-Nanojuncetea) from the southern Gülper See in northeast Germany (Fischer et al., 1995; Wichmann et al., 2000; Burkart et al., 2003). The subspecies grows there in flat inundated areas with less than $50 \%$ vegetation cover accompanied by Eleocharis acicularis, Centaurium pulchellum and Agrostis stolonifera. Wheeler (1980) described subsp. ranunculoides as an element of the wettest parts of species-rich fens in the Peucedano-Phragmitetum Wheeler 1978 (Phragmitetea, Magnocaricion), in England and Wales, where it grows with Phragmites australis, Peucedanum palustre, Cladium mariscus and, especially, Hottonia palustris, Potamogeton coloratus and Utricularia spp. In Illtyd Pools (Wales, UK) subsp. ranunculoides grows in a partially exploited ombrotrophic bog complex, next to basiphilous fen vegetation, in marginal seepages and water channels accompanied by Apium inundatum, Littorella uniflora and Ranunculus omiophyllus (Meade and Wheeler, 1990).

There are further records of subsp. ranunculoides from coastal lagoon sites in Spain and Portugal, representing still more phytosociological classes, i.e.: (1) the Utricularietum exoleto-australis (Potametea); (2) the Hyperico elodis-Rhynchosporetum rugosae (Littorelletea); (3) the Anagallido-Juncetum bulbosi (Scheuchzerio-Caricetea); (4) the Typho angustifoliae-Phragmitetum australis (Phragmitetea); and (5) the Glycerio declinatae-Eleocharitetum palustris (Phragmitetea) (Costa et al., 1999). Phytosociological data analysed as Anagallido-Juncetum bulbosi with subsp. ranunculoides have also been reported from high altitude in the Grazalema Mountains of southeast Spain (at $780 \mathrm{~m}$ a.s.1.) (Aranega Jimenez, 2005). B. ranunculoides subsp. ranunculoides has been further described as a common taxon in the Preslio-Eryngietum corniculati Rivas Goday (1957) 1970 (Alliance Preslion cervinae, class Isoëto-Nanojuncetea) in Paul Arzila Nature Reserve, Portugal (Blanca et al., 2000) and from lakes in Ciudad Real, Spain (Velayos et al., 1989). Rivas-Martinez et al. (1980) reported subsp. ranunculoides as a common species in the Junco emmanuelis-Eleocharitetum multicaulis from Doñana National Park.

In the most southern and eastern regions of its Mediterranean range the phytosociology of subsp. ranunculoides is not very well documented - or understood. In Corsica and Spain (and perhaps in North Africa) there are records of this subspecies in Atlantic/ west Mediterranen Quillwort swards: i.e. communities dominated by Isoëtes velatum. This vegetation is typical of shallow lake and pool shores, poor in organic matter and with variable (between 10 and $30 \mathrm{~cm}$ ) water levels, 
which generally tend to dry out during the summer (Velayos et al., 1989; Jeanmonod and Burdet, 1991; Grillas et al., 2004). In Sardinia, subsp. ranunculoides has been observed in small water-bodies inundated to $60-80 \mathrm{~cm}$ in spring, with Ranunculus baudotii, $R$. ophioglossifolius, Callitriche stagnalis and Potentilla reptans as its main associates (Bocchieri and Iiriti, 2003). In Tunisia (Kroumirie close to Aïn Draham) there are accounts of subsp. ranunculoides from peaty substrates with Potamogeton polygonifolius, Ludwigia palustris, Potentilla reptans, Schoenus nigricans, etc. (Braun-Blanquet, 1953) - but note comments elsewhere over the taxonomic uncertainty of this record. In northwest Greece, Dimopoulos et al. (2005) described subsp. ranunculoides from Kalodiki Fen growing in a community dominated with Gratiola officinalis, which might have a transitional status between the LolioPotentillion anserinae Tx. 1947 (from the MolinioArrhenateretean class) and the Magnocaricion elatae Koch 1926 (Phragmitetea). This association with Gratiola officinalis has been observed elsewhere in Padule di Fucecchio (Italy), where subsp. ranunculoides grows with other helophytes, e.g. Ludwigia palustris, Bolboschoenus maritimus (Corsi, 2001) and also in the Forêt d'Orléans, central France (personal observation).

$B$. ranunculoides subsp. repens: Since this taxon has not always been differentiated within phytosociological studies, its exact classification and the list of its communities throughout Europe and North Africa probably remains incomplete. Casper and Krausch (1980) described subsp. repens as a characteristic species of the Eleocharitetum multicaulis Allorge 1922 ex Tx. 1937 (alliance Eleocharition multicaulis, class Littorelletea), which grows mainly around oligotrophic lakes and pond shores. In some regions of western Europe, however, subsp. repens forms very large and dense stands within carpets of Eleocharis acicularis (so-called "woof/warp communities") (Schoof-van Pelt, 1973; Weeda et al., 1991; Brouwer et al., 1999; Brouwer and Roelofs, 2001; and personal observations) and these observations suggest that subsp. repens should probably be treated as one of the characteristic species of the Eleocharitetum acicularis (Koch, 1926) Oberd. 1957 (alliance Eleocharition acicularis Pietsch 1967 ex Dierssen 1975, class Littorelletea).

The strong affinity between subsp. repens and Eleocharis acicularis has been noted in even some of the older literature. Chouard (1924), for example, reported subsp. repens as a dominant element of pond shore communities with E. acicularis in Brigueil l'Aîné and a similar situation is described from pond sites elsewhere in France, such as the Forêt d'Orléans (Gaume, 1924). Oberdorfer (1977) and Passarge (1999) noted that variability and distribution in the Eleocharitetum acicularis and its characteristic species was still very little understood, although they recognised a very broad European distribution. They proposed that, besides the Continental type, a second, more Atlantic variant with Baldellia spp. still needed to be described. The most detailed description of this affinity between subsp. repens and the Eleocharitetum acicularis comes from Schoof-van Pelt (1973). She described a new subassociation dominated by subsp. repens and Eleocharis acicularis from a number of sites in Holland and France, growing on sandy soils covered with a thin layer of mud or organic matter (very often as flood débris). In addition to Eleocharis acicularis, the most common associates of subsp. repens were Littorella uniflora, Elatine hexandra, Hypericum elodes, Luronium natans, Damasonium alisma, Eleocharis multicaulis, Ranunculus flammula, Hydrocotyle vulgaris and Juncus bulbosus (Chouard, 1924; Gaume, 1924; Schoof-van Pelt, 1973; Weeda et al., 1991; Brouwer et al., 1999; Brouwer and Roelofs, 2001; and personal observations).

\section{Response to abiotic factors}

Baldellia spp. are morphologically very plastic and respond to changes in environmental conditions (and especially to nutritional and hydrological change) by adjustments to their growth and physiology (Glück, 1905; Meyer, 1932; Tomlinson, 1982).

All Baldellia taxa are described as light-demanding (Landolt, 1977; Ellenberg et al., 1992) but they can also occur in more shaded conditions, for example, in narrow canals surrounded by higher vegetation (e.g. a street channel near Yverdon in Switzerland; a drainage system in dune pools in Marquenterre, France; personal observations). Growth is, however, very much reduced under shade and plants only form small populations, with correspondingly low shoot density. The average leaf size is reduced in very shaded situations and plants do not generally produce either flowers or fruits (Glück, 1906) (Table 2).

All Baldellia taxa also prefer oligo- to mesotrophic conditions, although $B$. ranunculoides subsp. ranunculoides can be found on both completely bare, sandy shorelines (Wichmann et al., 2000; Burkart et al., 2003) and also in disturbed habitats where there is some local enrichment (Palmer and Roy, 2001). B. ranunculoides subsp. repens can also occur in more mesotrophic habitats (Brouwer et al., 1999; Brouwer and Roelofs, 2001). In both subspecies the forms growing in nutrientpoor habitats are much smaller and dwarf forms can often be observed (Glück, 1906).

Temperature plays an important part in the development - and thus in the distribution - of Baldellia spp. As Atlantic-Mediterranean taxa they are practically restricted to regions with a January mean temperature above $-2{ }^{\circ} \mathrm{C}$ (Jäger, 1968) or above $-1{ }^{\circ} \mathrm{C}$ (Krausch, 1985 ) and appear to be intolerant of strongly fluctuating 
temperatures (Glück, 1905). In subsp. ranunculoides, the emergent leaves usually disappear during the winter and in central and northern Europe plants only persist as corms with submerged linear leaves (Glück, 1905). By contrast, subsp. repens can continue growth throughout the year. Notably, cultivated material of the hybrid subsp. repens $\times$ subsp. ranunculoides appeared to successfully maintain underwater linear leaves and remain undamaged for several days of temperatures down to $-6{ }^{\circ} \mathrm{C}$, entirely covered by ice (personal observations).

Baldellia spp. are typical of many aquatic macrophytes that germinate, grow and reproduce entirely in water or in very wet habitats. Although they can endure drier periods, for even up to several months, Baldellia taxa cannot tolerate total or prolonged desiccation of the habitat (Cook, 1983) and subsp. ranunculoides grows best in shallow water, of $5-20 \mathrm{~cm}$ depth. FernandezAlaez C. (1999), studying the effects of water-fluctuation on the vegetation of small lakes in northwest Spain found the optimum growth of subsp. ranunculoides to be at depths of between 20 and $40 \mathrm{~cm}$ with no growth below that. $B$. ranunculoides subsp. repens seems to grow best in slightly shallower conditions. In both subspecies, however, the terrestrial forms produce 2-3 times more flowers and are much smaller - producing dwarf forms in very dry conditions (Glück, 1905, 1906). At the other end of the scale, in very deep water (from about $1-1.5 \mathrm{~m}$ depth), B. ranunculoides s.l. appears to develop only linear leaves without stomata and to become completely sterile (Glück, 1906). B. ranunculoides subsp. repens and subsp. ranunculoides have both, however, been observed growing at more than $4 \mathrm{~m}$ depth (Glück, 1906), which is similar to the maximum depth (c. $5 \mathrm{~m}$ ) for some other plants of the Helobiae-group such as Potamogeton spp. and Najas spp.

\section{Abundance}

In general, Baldellia taxa tend to have a very scattered, patchy population structure, even where they are relatively common and, as with many wetland plants of dispersed aquatic habitats, they are curiously rare in areas with suitable habitat, perhaps because these distributions represent a "metapopulation" structure, dependent upon active dispersal and recolonisation events.

In central Europe, subsp. ranunculoides and subsp. repens have both been strongly affected by major anthropogenic change during last two to three hundred years and some regional populations show a high degree of isolation, sometimes separated from each other by several hundred kilometres (e.g. populations on the Hiddensee Island, Rügen or in Lac de Neuchâtel, Switzerland). The presence of large areas of seemingly suitable but unoccupied habitats between populations in central Europe could be explained by local edaphic and climatic conditions (Krausch, 1985, 1996). Throughout the range of both subspecies there are very few regions with a high population density. B. ranunculoides subsp. ranunculoides is probably most abundant in western Ireland where it is still relatively frequent in suitable water-bodies (Preston et al., 2003); for subsp. repens, the pond-rich Sologne region in central France appears to be one of the few areas with a high concentration of sites (personal observation). B. ranunculoides subsp. ranunculoides tends to be infrequent, even within occupied sites, growing as scattered individuals and rarely exceeding $30 \%$ cover-abundance whereas, by contrast, subsp. repens is able to gain local dominance close to 100\% (Jones, 2006; personal observation).

\section{Life cycle and biology}

\section{Life cycle}

All Baldellia taxa are perennial helophytes with complex life cycles, exhibiting a range of vegetative and sexually reproductive strategies. The production of seeds, shoots and (in some taxa) new inflorescence stolons occurs every year. New sites are probably colonised by means of seeds and detached buds (dispersed by birds and water movement) (Glück, 1906; Vuille, 1988). The seeds are capable of germinating within a few weeks of ripening, so seedlings can appear during the growing season (although seeds usually remain attached to the receptacle for about 4-6 weeks). Seedling establishment only occurs in open aquatic conditions and usually in about $10-15 \mathrm{~cm}$ depth of water. After germination (in both subspecies) 4-5 ribbonlike leaves grow within about 3-4 weeks in shallow water and floating leaves with a lanceolate blade subsequently grow to the water surface. Seedlings rarely flower in their first year but will readily flower in their second year. The corms of both subspecies seem to last for at least three years with new corm buds appearing every year - at least in subsp. ranunculoides. In favourable conditions, these clonal offspring are potentially very long-lived. Baldellia ranunculoides subsp. repens produces leaves early in the year and existing rosettes will first produce one or more lateral vegetative shoots, which in turn grow ribbon-like-leaves and further elongated vegetative shoots. Floating leaves or directly upright lanceolate leaves will emerge depending on temperature and water depth. Both subspecies produce flowering shoots in May-June with a maximum growth of leaf cover by about August-September. In the case of subsp. repens this can form a dense carpet of lanceolate floating leaves with a network of underlying rosettes, partly connected to each other by 
dead and living inflorescence stolons. By November most of the still partly connected rosettes start to grow ribbon-like overwintering leaves.

Inflorescence stolons (runners) are a very efficient mode of vegetative spread in subsp. repens and usually produced after flowering (from September to December) and in the early spring (March-April) giving rise to several "daughter" plants (average 5; max. 8). They range from a few centimetres length to over $50 \mathrm{~cm}$ (Vuille, 1988), but generally seem to die off after a year or so (in contrast with the perennial corms). Pseudovivipary is central to the ecology and reproductive strategy of subsp. repens but hardly important (if at all) in subsp. ranunculoides.

In subsp. ranunculoides the first flowering stems are produced from early to mid summer - depending on geographical location. Vuille (1988) observed that subsp. ranunculoides with its self-compatible flowers and lack of inflorescence stolons shows some of the reproductive strategies of annual plants i.e. a short, intensive flowering period with numerous flowers followed by abundant fruits, with high seedling viability. This taxon also demonstrably invests more resources in sexual reproduction than subsp. repens (Vuille, 1988). In this context, subsp. ranunculoides might be described as an r-strategist, whilst subsp. repens tends to be Kstrategist (MacArthur and Wilson, 1967; Pianka, 1970; Grime, 1977; Jones, 2006).

\section{Spatial distribution of plants within populations}

In general, subsp. ranunculoides grows as a few scattered or even solitary plants on the edge of relatively closed, tall-herb vegetation. B. ranunculoides subsp. repens by contrast, is found abundantly in more open, species-poor associations (Table 2). This represents a major difference in population structure between Baldellia taxa, reflecting the pattern of extensive clonal growth in subsp. repens and the primarily sexual reproduction and short-distance vegetative reproduction (by corm-buds) of subsp. ranunculoides (Vuille, 1988; Jones, 2006). Thus, subsp. ranunculoides almost never forms monospecific stands and the population density tends to be relatively weak (forming dense - but highly localised - tussocks). Well-established stands of subsp. repens, by contrast, often have a very high shoot density and can frequently establish relatively large, locally dominant (even monospecific) stands. In the exposed, draw-down zone of gently shelving lakes, for instance, subsp. repens can form patches from several square metres to $1000 \mathrm{~m}^{2}$. The shoot density in such stands ranges from c. 10 to 100 shoots (rosettes) $/ \mathrm{m}^{2}$ (personal observation). In drier, nutrient-poor conditions or soon after establishment Baldellia taxa (especially subsp. ranunculoides) tend to grow in very loose stands or even as solitary individuals. The final size and structure of populations and their density depends on the patchiness and relative age of the habitat.

\section{Phenology}

B. ranunculoides subsp. ranunculoides: Shoot elongation starts in spring and shoot height increases until the end of May-June, reaching a peak after the formation of the inflorescence. In central and north Europe subsp. ranunculoides flowers from June to August (Casper and Krausch, 1980) whereas, in southern regions (e.g. Andalucia in Spain), it may flower as early as March and can be finished flowering before June (Valdes et al., 1987). Since, however, plants react strongly to variations in water level, this shoot development and flowering time can occasionally be shifted back, even into late autumn. Furthermore, seed-germination can also occur within a month or so of fruit-ripening, during the same year (Glück, 1906) so, especially in larger and more extensive populations, it is possible to find flowering and regenerating plants from May up to the end of October. Water, nutrients and assimilates are then transferred into the rhizomes after flowering, the plant overwintering as seeds and/or rhizomes whilst all above-ground shoots die back in late autumn. The only tissue able to grow during winter (in unfrozen water) are the submerged, ribbon-like leaves (Glück, 1906).

$B$. ranunculoides subsp. repens: The inflorescence stolons start to elongate during late winter and early spring, before the "true" sexual inflorescence develops (Vuille, 1988) which, in central and northern Europe, is from June to October (Casper and Krausch, 1980). Meiosis follows the development of floral parts, although the timing of this varies between populations.

Both subsp. ranunculoides and subsp. repens show clinal variation, as demonstrated in greenhouse experiments (Vuille, 1988). For populations of subsp. ranunculoides from northern Europe, flower-production reached a peak in May-June whilst, for more southerly populations, this occurred about a month later. Vuille (1988) concluded that earlier flowering is an adaptation to cooler climatic conditions in the more northerly populations and is probably dependent on photoperiod. Notably, the situation with subsp. repens is (under greenhouse conditions) the reverse, where southern populations actually flowered 3-4 weeks earlier than those from the north.

\section{Reproduction}

Baldellia spp. exhibit both sexual and vegetative reproductive strategies, with a strong tendency towards flowering every year. The flowers are very ephemeral, being open for only $2-4 \mathrm{~h}$ with, additionally, only $1-2$ 
flowers opening at the same time in any single pseudowhorl (Glück, 1906; Vuille, 1988). The flowers are insect-pollinated although Vuille (1988) demonstrated a trend in Baldellia toward self-pollination. The same tendency can be observed in the closely related genus Damasonium (Vuille, 1987) and it has been proposed that the evolution of self-pollination may be influenced by environmental factors restricting pollendispersal (Wells, 1979). Jain (1976), for instance, suggests that self-compatibility represents a selective advantage for species occupying unstable habitats or where new populations tend to be established by single founder individuals (which is the case for Baldellia and for many other plants of aquatic habitats). Durka (2002) proposed that Baldellia, in which different cytotypes and ploidy level occur, could be an example of linked ploidy levels and self-incompatibility. He speculated that an originally self-incompatible Baldellia sp. became selfcompatible through polyploidization. This would suggest that subsp. repens is the "ancestral" taxon. Small flies (Diptera) have been observed as pollinators (personal observation) but the exact pollinator spectrum and possible differences between Baldellia taxa have not been studied so far. The nectar is exuded in the form of 12 droplets on the inner surface of the anther ring, 6 at the base of the anthers and 6 more in between (Glück, 1906).

B. ranunculoides subsp. ranunculoides is self-compatible and facultatively outcrossing, whereas subsp. repens is strongly self-incompatible. B. ranunculoides subsp. repens has the typical characteristics of an insectpollinated plant with high-contrast floral elements (showy pink or purple petals with glitzema and yellow anthers) as well as pollen reward and nectar production with large stigma (Fig. 6). B. ranunculoides subsp. ranunculoides has smaller and less contrasted flowers. It has been proposed that in subsp. ranunculoides pollination can occur in submerged flower buds (cleistogamy) (Vuille, 1988; Preston and Croft, 2001) and Vuille (1988) has further demonstrated that selfcompatible subsp. ranunculoides invests more resources in sexual reproduction than subsp. repens (with more flowers and heavier, more numerous nutlets). The ripe nutlets (achenes) can stay for up to 4 months on the receptacle before falling, usually directly, into water or at the base of the plant. The nutlets can be dispersed by water (hydrochory) or by attachment to water birds (epizoochory) (Glück, 1906; Serbanescu-Jitariu, 1973). The strongly papillose nutlet of subsp. repens may offer some advantage in this respect. The concentrations of dense and persistent fruit-clusters (especially in subsp. ranunculoides) appear to be well adapted for waterfowl and seed heads in the wild often seem to have been grazed - but, as with many aquatic organisms, there is very little detailed information on their dispersal (Figuerola and Green, 2002). Dispersal by means of water movement is certainly facilitated by the very light and corky parenchyma of the nutlet wall.

Vuille (1988) observed three different means of vegetative propagation in Baldellia: (1) corm buds developing by division of the basal corm into 1-2 lateral buds; (2) runners developing through stem-elongation (these act either as an inflorescence, bearing flowers and rooting at the nodes - or grow purely vegetatively as stolons, in subsp. repens); (3) pseudovivipary through the production of vegetative buds in the inflorescence, developing into plantlets. Vegetative reproduction is reduced during flowering for all Baldellia taxa and mostly occurs during late winter or, with inflorescence stolons, in early spring and at the end of flowering (i.e. pseudovivipary).

\section{Germination}

Seeds of subsp. ranunculoides and subsp. repens can both germinate a few weeks after ripening (although more usually after about a month). The capitulae break apart and dry nutlets fall down close to the mother plant where they may float for several days and disperse or, eventually, sink under water. The seeds need to be fully immersed for germination but also seem to be more successful in fluctuating water levels (personal observation). The average germination ratio in samples of Baldellia spp. was found to be about $30 \%$ (personal observation). After germination, the small plants either anchor directly into their substrate or, occasionally, rise to the surface where they may continue growing and disperse (Cronk and Fennessy, 2001). Later on they can again sink and install themselves to the substrate with secondary roots (since the primary root is ephemeral). Seedlings appear to develop best in shallow water, between 5 and $15 \mathrm{~cm}$ depth (Glück, 1906; SerbanescuJitariu, 1973) but germination can, occasionally, take place directly on the mother plant, especially when a fruiting inflorescence is covered by water (Glück, 1905). As in other species of the Alismataceae, germination is phanerocotylar (Fig. 9): the hypocotyl internode is present and relatively long with an inconspicuous seedling collar. The cotyledon is elongated, assimilatory and more or less cylindrical, without any stomata. The first leaf is dorsiventral and can appear within two days of germination: all primary leaves are linear (Raunkiaer, 1895; Glück, 1906; Watson and Dallwitz, 1992).

\section{Response to competition and management}

All species of Baldellia are weak competitors and generally restricted to naturally open or disturbed habitats where competition with more robust species is reduced (Preston and Croft, 2001). Brouwer et al. (1999) documented a decrease in subsp. repens populations 


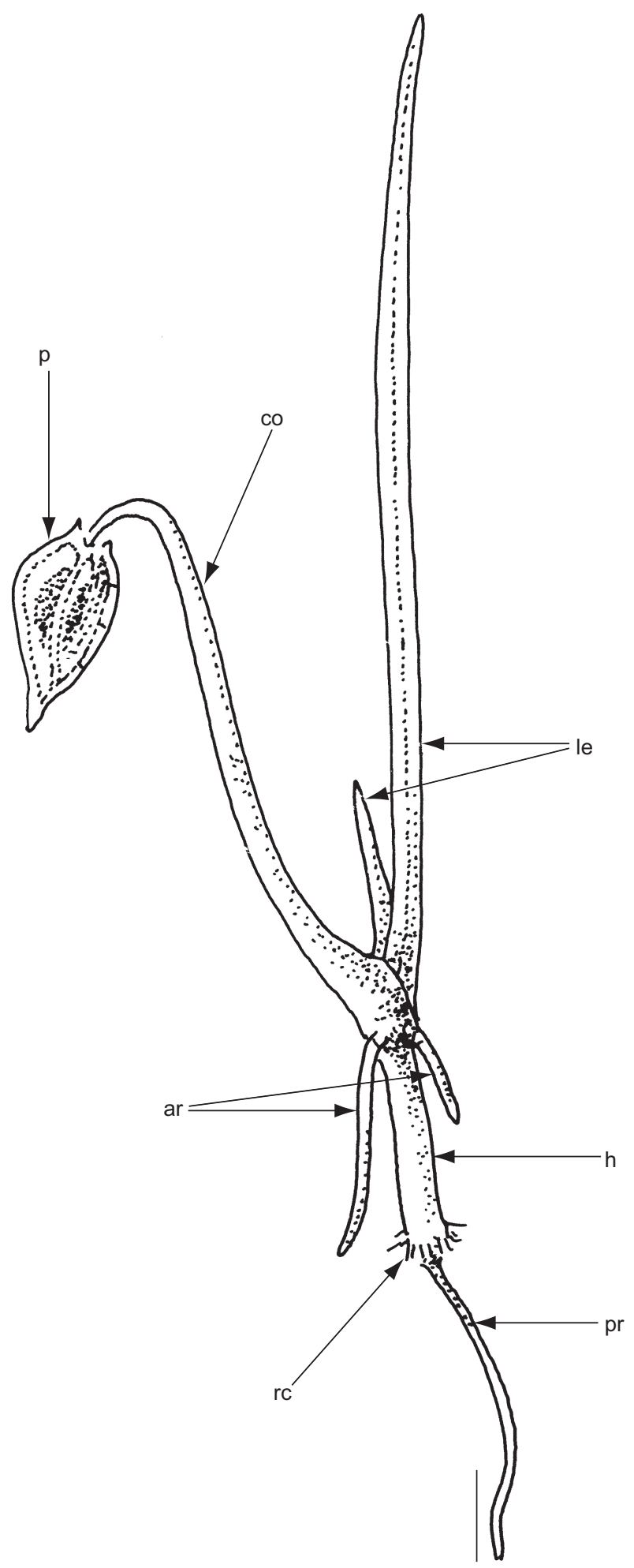

Fig. 9. Seedling morphology of $B$. ranunculoides subsp. ranunculoides. Abbreviations: ar - adventitious roots, co cotyledon, $\mathrm{h}$ - hypocotyl, le - first leaves, $\mathrm{p}$ - pericarp, $\mathrm{pr}$ primary root, rc - root collar with rhizoids (scale bar: $1 \mathrm{~mm}$ ). Drawn by S. Eggenberg. from the originally softwater Lake Banen in the Netherlands, due to eutrophication and increased alkalinity (caused by inputs of sulphate-rich water from the River Meuse). There were three steps in the observed degradation and disappearance of isoetid species: first, the initially isoetid vegetation was invaded by macrophytes from more mesotrophic and eutrophic habitats (e.g. Characeae, Elodea canadensis, Utricularia australis) coupled with rapid reed (Phragmites australis) growth. After this, persistent algal blooms led to the disappearance of all softwater species (including subsp. repens) and, finally, the remaining macrophytes disappeared with the formation of a fine black mud. B. ranunculoides subsp. repens is, therefore, particularly sensitive to both eutrophication and increased alkalinity - and to the spread of more competitive species. As with many other aquatic plants of pioneer conditions, the main difficulty is to create and maintain a disturbance regime which leads neither towards neglect nor to excessive damage (Willby and Eaton, 1993; Nielsen et al., 2006).

There are very few studies on the influence of restoration-management techniques for Baldellia taxa. Brouwer et al. (1999) and Brouwer and Roelofs (2001) reported on a large scale "mesocosm" restoration experiment at the subsp. repens site in Lake Banen contaminated by the River Meuse (above). In 1989, at the start of this experiment, subsp. repens only survived at one locality in the lake complexbut, after cutting off river inputs and removing mud layers most of the typical macrophytes of alkaline/eutrophic waters disappeared and softwater plants spread (and later came to dominate the site). By 1995 subsp. repens had been observed (often as the dominant taxon) in a number of localities, together with 12 other Netherlands Endangered species. Brouwer et al. (1999) concluded that subsp. repens had regenerated in this time from a viable seed bank (rather than by dispersed seed or from vegetative fragments of the remnant population) and that the most important factor in this recovery was the removal of degraded sediment.

Loucougaray et al. (2004) studied the effect of grazing by horses and cattle on the plant diversity of coastal grasslands in western France. They showed that subsp. ranunculoides grew well in grazed wet depressions, under traditional (probably centuries-old) grazing management. In a similar habitat in west Wales, however (at Hen Afon Leri fields, Ceredigion), subsp. ranunculoides was seen to disappear from damp coastal pasture when grazing by cattle and horses was removed, leading to overgrowth by Phragmites (A.O. Chater, pers. comm.). In general, the impacts of livestock on Baldellia taxa have dual and contradictory effects: they can decrease the overall population size by trampling and/or eutrophication but can also effectively reduce competition and create new sites favouring pioneer species (Wichmann et al., 2000; Grillas et al., 2004). 
Raabe and van de Weyer (1998) evaluated the effectiveness of "species protection water-bodies" (Artenschutzgewässer), used in North Rhine-Westphalia (Germany) since 1981 for the protection of endangered plants and animals. These newly created or restored pools and ponds were originally conceived only for the benefit of amphibians but, in 1988, colonies of subsp. ranunculoides were found to be present in 5 such water bodies - although they all quickly disappeared due to further ecological succession. The long-term survival of subsp. ranunculoides depends, therefore, on active protection measures: the regular removal of woody species, mowing and/or livestock-grazing, removal of mud layers and the creation of new bare ground. There are also some additional data - partially concerning the management of Baldellia taxa - in Grootjans et al. (2002) and Grillas et al. (2004) studies of the effects of conservation measures on Atlantic and Mediterranean dune slacks and temporary dune pools.

\section{Herbivores}

There is very little information relating to the effects of herbivory on Baldellia spp. Loucougaray et al. (2004) observed subsp. ranunculoides responding well to a range of different horse and cattle grazing regimes on coastal grasslands in the Marais Poitevin, western France. These observations could illustrate a relatively high resistance to grazing but did not provide any detailed information on actual consumption rates and levels of plant damage. B. ranunculoides subsp. repens has been observed in the shallow parts of Lake Banen, Holland, growing in areas grazed intensively by horses. It grows there in very dense stands with no apparent damage from the high levels of grazing (personal observation). These plants are small and creeping, close to ground level and it is therefore possible that they resist the effects of heavy grazing through morphological adaptations and not through any other defense mechanism (e.g. chemical deterrent substances).

Elger et al. (2002) studied the palatability and susceptibility of aquatic macrophytes to the pond snail Lymnaea stagnalis in cut-off channels of the River Rhône floodplain in France. B. ranunculoides subsp. ranunculoides belonged to the intermediate group of choice vegetation and was mostly grazed by snails on the middle parts of the leaves. In non-choice as well as in choice experiments subsp. ranunculoides consumption was between 5 and $20 \mathrm{mg} / \mathrm{g}$ of dry weight consumed per day; these amounts placed subsp. ranunculoides in an intermediate position, as compared with other macrophytes (e.g. Berula erecta c. 15-60 mg/g, Luronium natans c. $15-35 \mathrm{mg} / \mathrm{g}$, and Nuphar lutea c. $5 \mathrm{mg} / \mathrm{g}$ and Potamogeton coloratus c. $1-5 \mathrm{mg} / \mathrm{g}$ ). In a similar study with plants from the River Ain floodplain in eastern
France, Elger and Barrat-Segretain (2004) demonstrated that snail-grazing reached its maximum between September and October. Neither of these studies gave any indication, however, of morphological adaptations and/ or on deterrent chemicals but Elger and BarratSegretain (2004) did conclude that palatability could be explained by the translocation of defense substances from leaves to perennial organs before winter - a phenomenon observed in other aquatic plants (Alcoverro et al., 2000). The fact that subsp. ranunculoides is only weakly palatable to invertebrate herbivores in spring supports other studies which show young, actively growing tissue to be richer in defense chemicals than senescent tissue (Bowers and Stamp, 1993; Dahler et al., 1995).

Elsewhere, Rodriguez et al. (2005) reported a steep decline (up to $99 \%$ ) in the density of aquatic macrophytes after the introduction of invasive crayfish, Procambarus clarkia, in the Chozas shallow lakes of northwest Spain. In this study, subsp. ranunculoides and many other rare species disappeared within 1-2 years of this introduction and, although this also corresponded with a general deterioration of water and habitat quality, the disappearance of Baldellia was directly attributed to this herbivory. Previous studies have also demonstrated that this crayfish has a strong preference for fresh plant food (Gutierrez-Yuritta et al., 1998).

\section{Mycorrhiza}

Microscopic arbuscular mycorrhizae (AM) have been detected in the fine root systems of subsp. ranunculoides from the Macchia Lucchese nature reserve in northwest Tuscany, Italy (Maremmani et al., 2003). The plants investigated grew in a slack at the back of the dune system and AM were found in $65 \%$ of all investigated plants. It was suggested that this low incidence of nonmycotrophic species indicates their inability to compete successfully with mycotrophic species.

\section{Physiological data}

There is a relative lack of available data on physiological processes in Baldellia spp. and a detailed discussion of this subject is not yet possible. Fernandez-Alaez M. (1999) has studied the nutrient uptake and accumulation in tissues of aquatic macrophytes from several lakes in northwest Spain and, by comparison with Chara sp. and twelve other angiosperms, subsp. ranunculoides belonged to the category with a higher concentration of nitrogen (on average $\mathrm{c}$. $2.5 \%$ of dry weight). In terms of its organic carbon ratio subsp. ranunculoides has a relatively lower concentration compared to the other sample macrophytes (c. $38 \%$ of dry weight). The concentration of phosphorus was intermediate, at c. $0.15 \%$ of dry weight. According to Garbey et al. 
(2004), however, subsp. ranunculoides has some of the lowest tissue phosphorus concentrations, compared to other aquatic macrophytes, which could be significant, since the availability and storage potential of nutrients (and perhaps especially phosphorus) plays an important role in the development and distribution of these species (Carr and Chambers, 1998; Wassen et al., 2005).

\section{Biochemical data}

The study of biochemical diversity in the Alismataceae is still in its early stages and there is almost no biochemical data on Baldellia spp. Tomlinson (1982) gives starch as a storage substance, mainly found in corms or rhizomes but also in the petioles, commonly in association with vascular bundles. The presence of latex-secreting canals (lactifers or schizogenous lacunae) in Baldellia spp. is unusual amongst the Alismataceae and very uncommon within monocotyledons generally (Meyer, 1932; Stant, 1963). Tomlinson (1982) reports the presence of tannins and flavonoids in some genera of the Alismataceae (without exact data on Baldellia spp.) but Dahlgren et al. (1985) indicate that anthocyanins and leucoanthocyanins are generally lacking. Species of Alisma (which are closely related to Baldellia spp.) are reported to be cyanogenetic whilst certain phenolic glycosides with caffeic acid, chlorogenic acid and quercetin occur in the wider order Alismatales (Dahlgren et al., 1985).

All Baldellia spp. have very strong coriander-like smell (Rodriguez-Oubina and Ortiz, 1991; Romero et al., 2003), whose chemical composition has not yet been studied. It is therefore unclear whether this odour has any chemical affinities with the powerful and penetrating aldehydic aroma occurring of Coriandrum sativum (Apiaceae). The smell of C. sativum is dominated by E-2-alkenals (volatile defense substances in plants) and E-2-alkenols (plant growth regulators and fungicides, e.g. long chain aldehydes Z-2-decenal, E-2decenal $\mathrm{C}_{10} \mathrm{H}_{18} \mathrm{O}$, E-2-dodecenal), and alcohols: E-2dodecenol, 1-dodecanol $\left(\mathrm{C}_{12} \mathrm{H}_{25} \mathrm{OH}\right)$ as well as betaionone $\left(\mathrm{C}_{13} \mathrm{H}_{20} \mathrm{O}\right)$, eugenol $\left(\mathrm{C}_{10} \mathrm{H}_{12} \mathrm{O}_{2}\right.$, phenolic monoterpene) (Eyres et al., 2005).

In traditional medicine the leaves of Baldellia are used for their "cooling" and "repelling" effect. An extract is claimed to stop bleeding and bloody urine and, applied to the breasts, "dries up the milk very soon" (www.xn-heilkruter-finden-vqb.de).

\section{Genetic data}

\section{Karyological data}

The basic chromosome number in the Alismataceae varies from $x=(5-) 7$ to 11(-13) (Dahlgren et al., 1985) and, for Baldellia, Darlington and Wylie (1955) gave $x=7,8,9$ (for a summary of all available chromosome numbers see Table 3 and Fig. 10). Thus, different chromosome numbers have been observed in the genus Baldellia: $2 n=14,16,18,20,22,30$. B. ranunculoides subsp. repens and subsp. ranunculoides have not always been clearly separated during chromosome-counting studies and possible misidentifications prevent any general conclusions for both subspecies (Lawalrée, 1959; Triest and Vuille, 1991). All these research findings should therefore be taken with caution or else

Table 3. Chromosome numbers of all Baldellia taxa

\begin{tabular}{|c|c|}
\hline Taxon Country & References \\
\hline \multicolumn{2}{|l|}{ B. ranunculoides subsp. ranunculoides } \\
\hline $2 n=14$ Denmark & Palmgren (1943) \\
\hline $2 n=14 ?$ & Delay (1948) \\
\hline $2 n=14$ Netherland & $\begin{array}{l}\text { Gadella and } \\
\text { Kliphuis (1963) }\end{array}$ \\
\hline $2 n=16$ Sweden & $\begin{array}{l}\text { Löve and Löve } \\
\text { (1944) }\end{array}$ \\
\hline $2 n=16$ Ireland & $\begin{array}{l}\text { Packer in Löve and } \\
\text { Löve (1961a) }\end{array}$ \\
\hline $\begin{array}{c}2 n=16 \text { Sweden, Germany, United } \\
\text { Kingdom, Switzerland, } \\
\text { Portugal, France }\end{array}$ & Björkqvist (1968) \\
\hline $2 n=16$ Spain & $\begin{array}{l}\text { Björkqvist et al. } \\
\text { (1969) }\end{array}$ \\
\hline $2 n=16$ France & Schotsman (1970) \\
\hline $2 n=16$ Spain & $\begin{array}{l}\text { Fernandez Casas } \\
\text { (1978) }\end{array}$ \\
\hline $2 n=16$ Spain & Pastor (1983) \\
\hline $2 n=16$ Germany, Portugal & $\begin{array}{l}\text { Vuille (1983, } \\
\text { unpublished) }\end{array}$ \\
\hline $2 n=16$ France & Uchiyama (1989) \\
\hline $2 n=16$ Germany, Sardinia & $\begin{array}{l}\text { Vuille (1986) in } \\
\text { Triest and Vuille } \\
\text { (1991) }\end{array}$ \\
\hline $2 n=16$ Spain & Silvestre (1993) \\
\hline $2 n=18$ Denmark & Hagerup (1944) \\
\hline $2 n=20$ Morocco & $\begin{array}{l}\text { Vogt and } \\
\text { Oberprieler (1994) }\end{array}$ \\
\hline $2 n=22 ?$ & $\begin{array}{l}\text { Clavier in } \\
\text { Darlington and } \\
\text { Wylie (1955) }\end{array}$ \\
\hline $2 n=30 ?$ & Dandy (1980) \\
\hline $2 n=30 ?$ & $\begin{array}{l}\text { Franco and Afonso } \\
\text { (1994) }\end{array}$ \\
\hline \multicolumn{2}{|l|}{ B. ranunculoides subsp. repens } \\
\hline $2 n=16$ Portugal & $\begin{array}{l}\text { Fernandes et al. } \\
\text { (1948) }\end{array}$ \\
\hline $2 n=16 ?$ & $\begin{array}{l}\text { Casper and Krausch } \\
\text { (1980) }\end{array}$ \\
\hline \multicolumn{2}{|l|}{ B. alpestris } \\
\hline $2 n=18$ Spain & Guillen et al. (1998) \\
\hline
\end{tabular}


treated as chromosome numbers for B. ranunculoides s.l. The only information on subsp. repens is in Fernandes et al. (1948) using plants collected in Malhadas (Portugal), with root tips counted during metaphase. Casper and Krausch (1980) in their monograph on aquatic plants in Europe also give $2 n=16$ for subsp. repens, but they probably used Fernandes et al. (1948) as their source.
The most common chromosome number in $B$. ranunculoides s.1. across Europe is $2 n=16$ (Table 3; Figs. 10 and 11). This number has so far been determined for populations in Sweden, Germany, Great Britain, Ireland, Switzerland, France, Spain and Portugal (Löve and Löve, 1944, 1961a; Björkqvist, 1968; Björkqvist et al., 1969; Schotsman, 1970; Fernandez Casas, 1978; Pastor, 1983; Uchiyama, 1989; Triest and

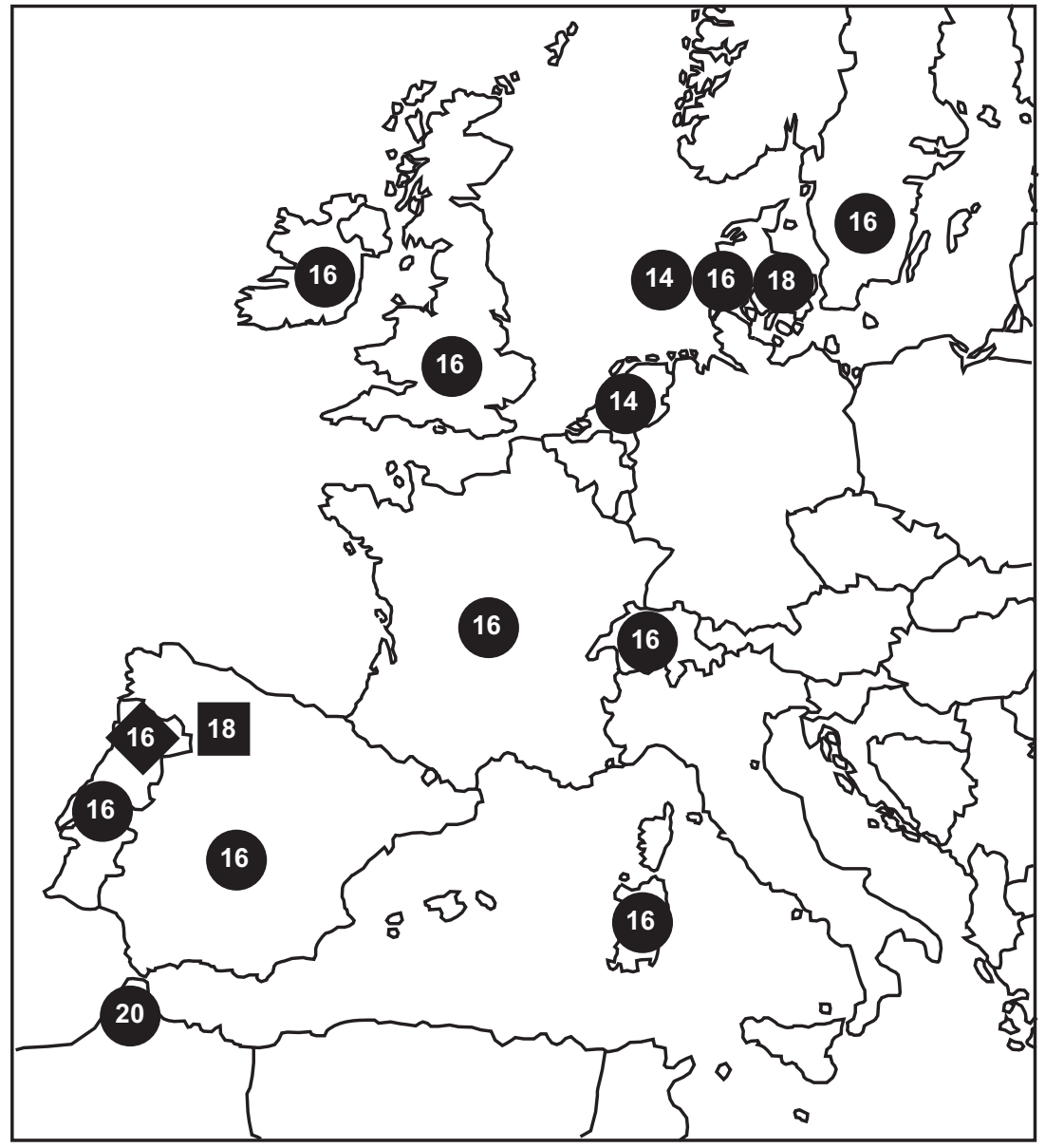

Fig. 10. Known chromosome numbers $(2 n)$ of the genus Baldellia across its geographical range. Circles: $B$. ranunculoides subsp. ranunculoides; diamond: $B$. ranunculoides subsp. repens; square: B. alpestris. For $B$. ranunculoides subsp. ranunculoides the representation is schematic (one circle per one chromosome number per country/island). For B. alpestris and B. ranunculoides subsp. repens the symbols are situated approximately in the region where the plant material originated.

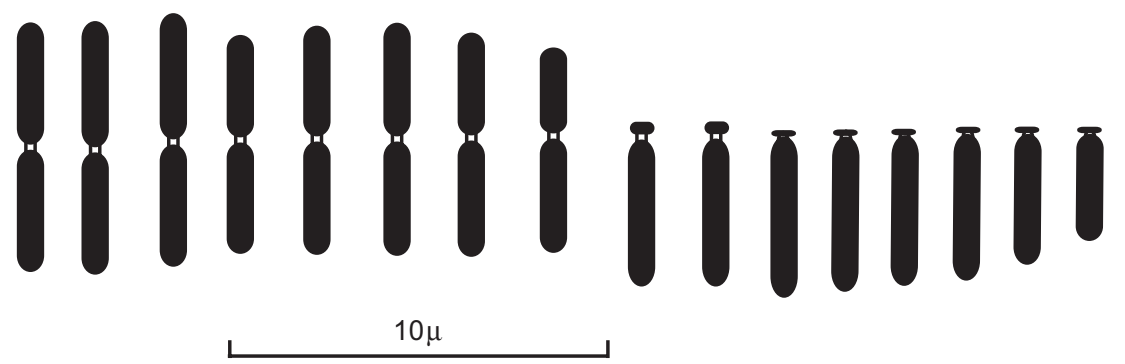

Fig. 11. Karyogram of B. ranunculoides subsp. ranunculoides $(2 n=16)$. Plant material collected in Portugal (Mentemor-o-Velho). 
Vuille, 1991; and Silvestre, 1993). The lower chromosome number of $2 n=14$ was reported by Palmgren (1943) from Denmark, by Gadella and Kliphuis (1963) from Holland and also by Delay (1948) for material of unknown origin. Higher chromosome numbers were reported by Hagerup (1944) for Denmark, with $2 n=18$; by Vogt and Oberprieler (1994) for Morocco with $2 n=20$; by Clavier (unpublished data of unknown provenance, noted by Darlington and Wylie, 1955) with $2 n=22$; and, finally, $2 n=30$ given by Dandy (1980) in Flora Europaea and by Franco and Afonso (1994) in their Flora of Portugal. Neither of these two Floras provides any source, however, for the higher counts. Hess et al. (1977) noted the morphological similarity between the chromosomes of Baldellia and Alisma and this observation is confirmed by Uchiyama (1989) in his comprehensive karyomorphological studies of the Alismataceae and other related families. The chromosome morphology at interphase and mitotic prophase were almost identical with that of Asiatic Alisma plantagoaquatica subsp. orientale Samuelson. This observation, as well as the similar chromosome numbers and presence of a similar aneuploid series underline the close relationships between these two Alismatacean genera.

From these chromosome numbers it is very likely that Baldellia shows a similar aneuploid series to that observed in the closely related genus Alisma: $2 n=10$, 12, 14, 16, 24, 28, 34 (Baldwin and Speese, 1954, 1955; Hess et al., 1977) and in some other groups of flowering plants (e.g. Astragalus: Wojciechowski et al., 1993; Claytonia: Lewis, 1962; Amsinckia: Ray and Chisaki, 1957). It has been proposed that dysploidy (or "aneuploidy" in some sources) is an important factor in the evolution and diversity of many groups of vascular and non-vascular plants (Camp and Gilly, 1943; Polhill and Raven, 1981; Wojciechowski et al., 1993) and this phenomenon could be responsible for some of the adaptive radiation in Baldellia, reflecting specialised edaphic conditions and extreme microhabitats. Manning and Goldblatt (2001) also suggest that ascending dysploidy is rare in plants compared to descending dysploidy and this hypothesis could be supported within the Alismataceae, if the chromosomally stable genera (i.e. Echinodorus $n=11$ and Sagittaria $n=11$ and 10) possessed the ancient chromosome numbers. Baldellia and Alisma, by contrast, would seem to show descending dysploidy $(n=11,10,9,8,7)$ in this model. According to Favarger (1980), such taxa with a pure dysploid series (without polyploidy) would appear to be undergoing strong evolutionary processes although the high count of $2 n=30$ reported by Dandy (1980) could be an example of polyploidy (4n) (Durka, 2002).

Rye and James (1992) demonstrated that dysploid reduction in the Myrtaceae serves the short-term advantage of ensuring greater genetic uniformity through reduced recombination and Selvi and Bigazzi (2002), studying several species of Nonea (Boraginaceae) from Turkey, proposed that descending dysploidy was associated with shorter life cycles, as an adaptation to difficult or unstable ecological conditions. Since the chromosome counts in Baldellia spp. are still relatively patchy, it is not yet clear if any descending (or ascending) series of chromosome numbers is either geographically or ecologically patterned, as has been observed in other groups of plants (e.g. Strother and Brown, 1988). There do, nevertheless, seem to be two centres of high chromosome number diversification for Baldellia (Fig. 10): first in the Iberian peninsula and North Africa $(2 n=16,18,20)$ and secondly in southern Scandinavia and the Benelux countries $(2 n=14,16,18)$. In all other regions $2 n=16$ dominates. The high chromosomal variability in the Iberian peninsula could provide further support for this region as the centre of diversification and/or origins in Baldellia sp. (so-called centrifugal differentiation/evolution sensu Favarger, 1980). The presence of the second, highly differentiated, centre in the Netherlands and south Scandinavia shows, however, that dispersal and evolutionary processes in Baldellia could be very complex and will need still further investigations. Additionally, the centre of morphological variation of B. ranunculoides s.l. appears to lie in west-central France, so it is not clear if there is any correlation between clinal morphological variation and chromosomal patterns.

\section{Genetic variation}

There is very little available data on genetic variation in Baldellia. From studies of the isozyme variation in material collected from Spain, Portugal, UK, France, Holland, Belgium and Italy, Triest and Vuille (1991) clearly demonstrated two distinct groups, corresponding to the species $B$. ranunculoides s.l. and $B$. alpestris (with an average $41 \%$ genetic diversity). The genetic distance between subsp. ranunculoides and subsp. repens was, on average, only $11 \%$ and in cluster analysis, subsp. repens appears as one subgroup of subsp. ranunculoides. This could represent relatively recent and continuing evolution in subsp. repens (in contrast to the palaeoendemic subsp. ranunculoides). Recently, Jacobson (2003) studying the phylogeny of the genus Alisma using several genetic markers (RAPDs, allozymes, ITS and trnL sequences) showed, however, that there are clear differences between both subspecies of $B$. ranunculoides s.l. Furthermore, Triest and Vuille (1991) showed that subsp. repens has a higher genetic diversity between and within populations than subsp. ranunculoides - most likely due to their different reproductive biology: subsp. repens is self-incompatible whereas subsp. ranunculoides is capable of both outbreeding and self-compatibility. It 
is known that outbreeding aquatic plants generally exhibit more genetic diversity (Triest, 1991a). These results also confirm the general observation that aquatic plants only show very limited genetic diversity (Barrett et al., 1993), perhaps as a result of widespread clonal growth and multiplication as well as relatively frequent long-distance dispersal (Santamaria, 2002).

\section{Hybrids}

Hybrids between subsp. repens and subsp. ranunculoides are readily synthesised in cultivation and are both morphologically intermediate and self-compatible (Triest and Vuille, 1991). They are also able to back-cross with both parent subspecies (personal observation), holding out the possibility of introgression within hybrid populations in the wild. Under natural conditions, however, the two subspecies grow in different habitats so that pollen exchange is probably a rather rare phenomenon. Dupont (1990), for instance, observed that subsp. ranunculoides is not usually found in regions of France where subsp. repens is common. From a range of morphological and molecular data, however, Vuille (1988) and Triest and Vuille (1991) have demonstrated that at least some individuals from populations in Sardinia (and perhaps also in Portugal and France) could be regarded as natural hybrids. Jones (2006) also reported intermediate (and probably hybrid) plants from Pembrokeshire (UK) where acid and calcareous habitats both overlap in the same coastal heath complex. It is very likely that these hybrids have contributed significantly to a historical confusion over $B$. ranunculoides subspecies in certain parts of their range and to the reluctance of some botanists to accept these as well-marked and reliable taxa (e.g. Smith, 1828; N.Y. Sandwith manuscript at Kew). The new subspecies of $B$. ranunculoides described by Molina Abril et al. (1994) from Spain (subsp. cavanillesii) could be yet another hybrid example, with apparently intermediate morphology. Natural intergeneric hybrids with Baldellia are rarely described and doubtful. There are two reported hybrids with Alisma plantago-aquatica from Ireland and Morocco and one reported infertile hybrid with A. lanceolatum $(2 n=28)$ (Hess et al., 1977; Markgraf, 1981).

\section{Conservation status and threats}

The available information on the global conservation status in Baldellia taxa is fragmentary and very heterogenous but $B$. ranunculoides s.l. could be one of the most rapidly declining vascular plants in Europe (Preston and Croft, 2001; Jones, 2006). It has declined in practically all regions of central and northern Europe and even in countries where it is not officially listed as under threat (e.g. Ireland, Preston et al., 2003). There is no detailed information for the southern and eastern parts of its range but subsp. ranunculoides is listed as Extinct (IUCN category EX) in Estonia, Latvia, Lithuania, Sicily and Slovenia, and most probably in Poland. It is Critically Endangered (CR) in Croatia, Italy and Switzerland, Endangered (EN) in Belgium, Germany, the Netherlands and Sweden (Moser et al., 2002) and Near Threatened (NT) in Great Britain (Cheffings and Farrell, 2005). There is insufficient data for many other countries in its range and the conservation status of subsp. repens is not at all well documented. With the exception of Belgium, the Netherlands, Norway and Great Britain (where it is only listed at "Data Deficient"), subsp. repens is not even recognised in most published Red Lists.

B. ranunculoides subsp. ranunculoides is Critically Endangered in central Europe and strongly in decline throughout. It is Extinct in several Federal states of Germany and decreasing in practically all regions. Some new rediscoveries (Hiddensee, S. Fehrenz, pers. comm.) and successful conservation efforts (North RhineWestphalia, U. Raabe, pers. comm.) have not changed this general trend. Over $55 \%$ of occurrences in western Federal states, and c. $70 \%$ of historic populations in eastern Federal states could not be refound at the end of the 20th century (Haeupler and Schönfelder, 1988; Benkert et al., 1998). The same level of decline has been observed elsewhere in north Europe. B. ranunculoides subsp. ranunculoides is classified in Belgium as Endangered (EN), whilst subsp. repens is Critically Endangered (CR) (www.instnat.be); in the Netherlands, subsp. ranunculoides is Endangered (EN) and subsp. repens is classified as Vulnerable (VU) (Cools, 1989; Weeda et al., 1991). In Switzerland the situation is even worse (subsp. ranunculoides: category CR). From a former 51 recorded sites only four still exist today, with no more than 250-500 individuals in total (Käsermann and Moser, 1999; personal observation).

Habitat destruction, anthropogenic disturbance, hydrological alterations and changes in water and substrate quality seem to be the most significant threats to Baldellia subspecies but the list of observed and/or potential threats to these taxa and their habitats is very long. It includes lake shore development, recreational activities, the infilling of water bodies, successional overgrowth of ponds and heath pools used for stock watering, drainage of fens and wet meadows, the disappearance of ditches through agricultural improvement, flood-control management, water body and bank regularisation, disuse or drying out of canals, drainage, physical disturbance of sediments (wild boar digging, livestock trampling, vehicle tracks, etc.), eutrophication, pollution from a range of contaminants, acidification, enhanced carbon dioxide concentration and invasion by competitive species (Roelofs, 1983; Triest, 1991b; Cronk and Fennessy, 2001; Preston and Croft, 2001; Murphy, 
2002; Roelofs, 2002; Grillas et al., 2004; Kennedy and Murphy, 2004).

Taxonomy, in general, reflects ecological difference and the two subspecies of $B$. ranunculoides should also have their own distinct threats and management needs. The characteristic upright growth of subsp. ranunculoides, for instance, and its strong annual flowering and seedoutput all seem to be adaptations to more productive habitats - but also need high levels of disturbance. By contrast, the low-growing and largely vegetative subsp. repens seems morphologically (and perhaps physiologically) adapted to more naturally open, low-nutrient water bodies. It is probably also more vulnerable, however, to the effects of enrichment. And the two different breeding systems could also have differing ecological outcomes. For example, Baldellia - like many aquatic plants - tends to establish new colonies through individual founders but only populations of subsp. ranunculoides descended from a single plant can then regenerate from seed. Newly established populations of the self-incompatible subsp. repens and those at the edge of its geographical range are far less likely to be sexually fertile and are consequently more vulnerable to periodic crises such as successional overgrowth or drought.

The two subspecies undoubtedly have other selective advantages (the papillose nutlets of subsp. repens, for instance, seem better adapted to dispersal on mammals and birds) but there are still many gaps in their autecology. It is important to recognise, however, that the generalised taxon Baldellia ranunculoides s.l. actually conceals two (generally) distinct taxa and a range of differing conservation needs. These differences have been widely overlooked or misunderstood throughout the species' range with adverse consequences for its conservation as a whole. There is also a tendency in plant conservation to ignore subspecies (and hybrids) or at least to assess them collectively under a broader taxonomic grouping. There is a strong argument, however (as is commonly the case with vertebrates, for instance), to independently redlist these infraspecific taxa or at least to recognise the significance of variation, even when it does not fit into convenient taxonomic categories.

\section{Acknowledgements}

We would like to thank Benoît Clement and Susanne Bollinger of the University of Fribourg Botanic Garden (Switzerland) and Arthur Chater (Botanical Society of the British Isles) for their advice and technical help. We are much indebted to the Franklinia Foundation for its engagement and valuable support during the manuscript preparation and field work and, further, we thank Stéphanie Rion for collecting much of the distribution and conservation status data. The following experts (in country order) have all generously assisted in the preparation of the new distribution maps: Algeria Abdelkrim Hacène, Dept. de Botanique, Institut National Agronomique, University of Alger; Belgium Jacqueline Saintenoy-Simon A.M.B.E, Association pour l'Etude de la Floristique, Bruxelles; Croatia - Kristijan Civic, State Institute for Nature Protection; Denmark Henrik Ærenlund Pedersen, University of Copenhagen; Estonia - Mart Kùlvik, Head of Research Centre, Environmental Protection Institute \& Leht Malle, the Estonian Naturalist Society; France - Francis Olivereau, Diréction Régionale de l'Environnement de la Region Centrale; Germany - Uwe Raabe, Naturschutzamt Nordrhein-Westfalen \& Thomas Raus, Botanischer Garten Berlin; Italy - Salvatore Pasta, Tutela delle Specie Vegetali Prioritarie delle Isole Eolie, Sicily \& Anna Scoppola, Università Tuscia; Latvia - Viesturus Melecis, Institute of Biology, University of Latvia; Morocco-Mohamed Fennane, Dépt. de Botanique et d'Ecologie Végétale, University of Rabat; Netherlands Baudewijn Odé, Director of Stichting Floron, Leiden; Norway - Svein Baatvik, Directorate for Nature Management, Trondheim; Poland - Joanna Zalewska, Department of Plant Taxonomy and Phytogeography, Institute of Botany, Jagiellonian University; Portugal Paulo Alves and Rubim da Silva, University of Porto; Antonio Crespi, Botanic Garden, University of Tras-osMontes e Alto Douro, Vila Real; David Draper Munt, Museum Nacional de História Natural, Universidade de Lisboa; Hanno Schäfer, author of the Flora of the Azores; Slovenia - Mitja Kaligaric, Katedra za Geobotaniko; Spain - Ramon Casimiro-Soriguer, Dept. Biologia Vegetal y Ecologia, Universidad de Sevilla \& Oscar Sánchez Pedraja, Grupo Botànico Cantàbrico, Cantabria; Sweden - Arne Strid, Göteborg Botanical Garden.

\section{References}

Aedo, C., Aldasoro, J.J., Argüelles, J.M., Carlon, L., Diez Riol, A., Gomez Casares, G., del Valle, J.M.G., Guillen Oterino, A., Lainz, M., Moreno Moral, G., Patallo, J., Sanchez Pedraja, O., 2001. Contribuciones al conocimiento de la Flora Cantabrica. V. Bol. Cien. Nat. 47, 7-52.

Alcoverro, T., Manzanera, M., Romero, J., 2000. Nutrient balance of seagrass Posidonia oceanica: the importance of nutrient retranslocation. Mar. Ecol. Prog. Ser. 194, 13-21. 
Aranega Jimenez, R., 2005. Contribuciones a la flora vascular de Andalucia (Espana). Acta Bot. Malac. 30, 189-239.

Argue, C.L., 1974. Pollen studies in the Alismataceae (Alismaceae). Bot. Gaz. 135, 338-344.

Aronsson, M. (Ed.), 1999. Rödlistade kärlväxter i Sverige, vol. 1. ArtDatabanken SLU, Uppsala.

Arts, G.H.P., den Hartog, C., 1990. Phytogeographical aspects of the West European soft-water macrophyte flora. Acta Bot. Neerl. 39, 365-370.

Ascherson, P., Graebner, P., 1913. Synopsis der mitteleuropäischen Flora, second ed. Verlag von Wilhelm Engelmann, Leipzig.

Baldwin Jr., J.T., Speese, B.M., 1954. Chromosomes of representatives of Alismataceae in the range of Gray's Manual. Virginia J. Sci. (N. S.) 5, 260.

Baldwin Jr., J.T., Speese, B.M., 1955. Chromosomes of taxa of the Alismataceae in the range of Gray's Manual. Am. J. Bot. 42, 406-411.

Barcelo, F.B., 1977. Flore de Mallorca, vol. I. Editorial Moll, Mallorca.

Barrett, S.C.H., Eckert, C.G., Husband, B.C., 1993. Evolutionary processes in aquatic plant populations. Aquat. Bot. 44, 105-145.

Battandier, T.A., Trabut, L.C., 1895. Flore de l'Algérie, Monocotyledones (I-III). Girault, Alger.

Battandier, T.A., Trabut, L.C., 1905. Flore analytique et synoptique de l'Algerie et de la Tunisie. Girault, Alger.

Bazos, I., Yannitsaros, A., 2001. Rare plants from aquatic and semi-aquatic habitats of Lesvos island (east Aegean, Greece). Bocconea 13, 589-597.

Benkert, D., Fukarek, F., Korsch, H., 1998. Verbreitungsatlas der Farn- und Blütenpflanzen Ostdeutschlands. Ulmer, Stuttgart.

Björkqvist, I., 1968. Studies in Alisma L. II. Chromosome studies, crossing experiments and taxonomy. Oper. Bot. 19, 1-138.

Björkqvist, I., von Bothmer, R., Nielson, Ö., Nordenstam, B., 1969. Chromosome numbers in Iberian angiosperms. Bot. Notiser. 122, 271-283.

Blanca, G., Cabezudo, B., Hernandez-Bermejo, J.E., Herrera, C.M., Munoz, J., Valdes, B., 2000. Libro rojo de la flora silvestre amenazada de Andalucia. Tomo II: Especies vulnerables. Consejeria de Medio Ambiente. Junta de Andalucia. Imagénesis, Almonte.

Bocchieri, E., Iiriti, G., 2003. Flora di Teccu, un promontorio basaltico della Sardegna centro orientale. Atti Soc. Tosc. Sci. Nat. Ser. B 110, 35-53.

Bonnet, E., Barratte, G., 1896. Catalogue raisonné des plantes vasculaires de la Tunisie. Imprimerie Nationale, Paris.

Bournerias, M., Wattez, J.R., 1990. Esquisse phytogeographique de la Picardie, France. J. Biogeogr. 17, 145-161.

Bowers, M.D., Stamp, N.E., 1993. Effects of plant age, genotype, and herbivory on Plantago performance and chemistry. Ecology 74, 1778-1791.

Braun-Blanquet, J., 1923. L'Origine et le développement des flores dans le Massif central de France, avec aperçu sur les migrations des flores dans l'Europe sud-occidentale. Imprimerie A. Rey, Lyon, Léon Lhomme, Paris.

Braun-Blanquet, J., 1953. Irradiations européennes dans la végétation de la Kroumirie. Plant Ecol. 4, 182-194.

Brouwer, E., Roelofs, J.G.M., 2001. Degraded softwater lakes: possibilities for restoration. Rest. Ecol. 9, 155-166.
Brouwer, E., Soontiëns, J., Bobbink, R., Roelofs, J.G.M., 1999. Sulphate and bicarbonate as key factors in sediment degradation and restoration of Lake Banen. Aquat. Cons.: Mar. Freshwater Ecol. 9, 121-132.

Buchenau, F., 1882. Beiträge zur Kenntnis der Btomaceen, Alismaceen und Juncaginaceen. Bot. Jb. Syst. 2, 465-510.

Buchenau, F., 1903. Alismataceae. In: Engler, A., Prantl, K. (Eds.), Die natürlichen Pflanzenfamilien. Teil II. Abteilung 1. Verlag von Wilhelm Engelmann, Leipzig, pp. 1-61.

Bugnon, F., Loiseau, J.-E., Felzines, J.-C., Royer, J.-M., 1993. Nouvelle flore de Bourgogne. Bulletin Scientifique de Bourgogne (Edition hors série), Dijon.

Burkart, M., Wattenbach, M., Wichmann, J., Pötsch, J., 2003. Die Vegetation der unteren Havelaue: Stand der Forschung und Perspektiven. Brandenburgische Umwelt Berichte (BUB) 13, 57-71.

Camp, W.H., Gilly, C.L., 1943. The structure and origin of species. Part I: the species in biosystematy. Brittonia 4, 331-355.

Carr, G.M., Chambers, P.A., 1998. Macrophyte growth and sediment phosphorous and nitrogen in Canadian prairie river. Freshwater Biol. 39, 525-536.

Casper, S.J., Krausch, H.-D., 1980. Pteridophyta und Anthophyta. Teil 1. In: Ettl, H., Gerloff, J., Heynig, H. (Eds.), Süsswasserflora von Mitteleuropa. Band 23. VEB Gustav Fischer, Jena, pp. 157-184.

Cavanilles, A.I., 1791. Icones et descriptions plantarum quae aut sponte in Hispania crescunt aut in hortis hospitantur. Impremta Reial, Madrid.

Champion, P.D., Clayton, J.S., 2000. Border control for potential aquatic weeds. Science for Conservation 141, Wellington.

Charlton, W.A., 1968. Studies in the Alismataceae. I. Developmental morphology of Echinodorus tenellus. Can. J. Bot. 46, 1345-1360.

Charlton, W.A., 1972. Studies in the Alismataceae. II. Inflorescences of the Alismataceae. Can. J. Bot. 51, 775-789.

Charlton, W.A., 1973. Studies in the Alismataceae. V. Experimental modification of phyllotaxis in pseudostolons of Echinodorus tenellus by means of groeth inhibitors. Can. J. Bot. 52, 1131-1142.

Charlton, W.A., 2004. Studies in the Alismataceae. XII. Floral organogenesis in Damasonium alisma and Baldellia ranunculoides, and comparison with Butomus umbellatus. Can. J. Bot. 82, 528-539.

Charpin, A., Salanon, R., 1985. Catalogue floristique des Alpes Maritimes. Mémoires de botanique systématique. Boissiera, vol. 36. Genève.

Chas, E., 1994. Atlas de la flore des Hautes-Alpes. Conservatoire botanique nationale alpin de Gap, Charance.

Chase, W.M., Soltis, D.E., Olmstead, R.G., Morgan, D., et al. (39 others). 1993. Phylogenetics of seed plants: an analysis of nucleotide sequences from the plasmid gene $r b c \mathrm{~L}$. Ann. Missouri Bot. Gard. 80, 528-580.

Chen, J.-M., Chen, D., Gituru, W.R., Wang, Q.-F., Guo, Y.H., 2004. Evolution of apocarpy in Alismatidae using phylogenetic evidence from chloroplast $r b c L$ gene sequence data. Bot. Bull. Acad. Sin. 45, 33-40.

Chouard, P., 1924. Monographies phytosociologique. 1. La region de Brigueil l'Aîné (Confolentais). Bull. Soc. Bot. France (quatrième série) 71, 1130-1158. 
Cook, C.D.K., 1983. Aquatic plants endemic to Europe and the Mediterranean. Bot. Jahrb. 103, 539-582.

Cook, C.D.K., 1990. Aquatic Plant Book. SPB Academic Publishing, The Hague.

Cools, J.M.A., 1989. Atlas van de Nordbrabantse Flora. Stichting Uitgeverij van de Koninklijke Natuurhistorische Vereniging, Tilburg.

Cooper, A., McCann, T., Davidson, R., Foster, G.N., 2005. Vegetation, water beetles and habitat isolation in abandoned lowland bog drains and peat pits. Aquat. Cons.: Mar. Freshwater Ecol. 15, 175-188.

Corsi, R., 2001. La flora e la vegetatione. Centro di Recerca, Documentatione e Promozione del Padule di Fuecechio. Quaderni del Padule di Fucecchio 1, 23-120.

Cosson, E.S.-Ch., 1864. Description de deux espèces nouvelles d'Espagne. Bull. Soc. Bot. France XI, 332-333.

Costa, J.C., Capelo, J., Espirito Santo, M.D., Lousa, M., Monteiro, A., Mesquita, S., Vasconçelos, M.T., Moreira, I., 1999. Plant communities of the lagoons of the Portuguese Coastal Superdistrict - a multivariate approach. Hydrobiologia 415, 67-75.

Cronk, J.K., Fennessy, M.S., 2001. Water Plants: Biology and Ecology. Lewis Publishers, Boca Raton.

Cronquist, A., 1981. An integrated System of Classification of Flowering Plants. Columbia University Press, New York.

Cuénod, A., Pottier-Alapetite, G., Labbe, A., 1954. Flore analytique et synoptique de la Tunisie. Cryptogammes vasculaires, gymnospermes et monocotyledones. Office de l'experimentation et de la vulgarisation agricoles de Tunisie, Tunis.

Czeczott, H., 1926. The atlantic element in the flora of Poland. Bulletin International de l'Académie Polonaise des Sciences et des Lettres. Série B: Sciences Naturelles, 361-407.

Daghlian, C.P., 1981. A review of the fossil record of monocotyledons. Bot. Rev. 47, 517-555.

Dahler, J.M., McConchie, C.A., Thurnbull, C.G.N., 1995. Quantification of cynogenetic glycosides in seedlings of three Macadamia (Proteaceae) species. Aust. J. Bot. 43, 619-628.

Dahlgren, R.M.T., Clifford, H.T., Yeo, P.F., 1985. The Families of Monocotyledons - Structure, Evolution, and Taxonomy. Springer, Berlin.

Dandy, J.E., 1980. Baldellia Parl. In: Tutin, et al. (Eds.), Flora Europaea, vol. 5. Cambridge University Press, Cambridge p. 2.

Darlington, C.D., Wylie, A.P., 1955. Chromosome Atlas of Flowering Plants. George Allen \& Unwin Ltd., London.

Davies, H., 1813. Welsh Botanology - A systematic catalogue of the native plants of Anglesey, London.

Davis, P.H., 1984. Flora of Turkey and the East Aegean Islands, vol. 8. Edinburg University Press, Edinburgh.

de Bolos, O., Vigo, J., 2003. Flora dels Paisos Catalans. IV. Barcino SA, Barcelona.

Delay, C., 1948. Recherches sur la structure des noyaux quiescentes chez les phanérogames. Rev. Cytol. Cytophysiol. Vég. 10, 103-229.

Denys, L., 2003. Environmental changes in man-made coastal dune pools since 1850 as indicated by sedimentary and epiphytic diatom assemblages (Belgium). Aquat. Cons.: Mar. Freshwater Ecol. 13, 191-211.
Dimopoulos, P., Sykora, K., Gilissen, C., Wiecherink, D., Georgiadis, T., 2005. Vegetation ecology of Kalodiki Fen (NW Greece). Biologia (Bratislava) 60, 69-82.

Dines, T.D., Jones, R.A., Leach, S.J., McKean, D.R., Pearman, D.A., Preston, C.D., Rumsey, F.J. Taylor, I., 2005. In: Cheffings, C.M., Farrell, L. (Eds.), The vascular plant red data list for Great Britain. Species Status 7. Joint Nature Conservation Committee, Peterborough, pp. 1-116.

Dorken, M.E., Barrett, S.C.H., 2004. Phenotypic plasticity of vegetative and reproductive traits in monoecious and dioecious populations of Sagittaria latifolia (Alismataceae): a clonal aquatic plant. J. Ecol. 92, 32-44.

Dupont, P., 1962. La flore atlantique européenne. Documents pour les cartes des productions végétales. Série: EuropeAtlantique. Volume I. Tome: Généralités. Faculté des Sciences, Toulouse.

Dupont, P., 1990. Atlas partiel de la flore de France. Collection Patrimoines Naturelles, vol. 3. Série Patrimoine Génétique. Muséum National d'Histoire Naturelle, Paris.

Dupont, P., 2001. Atlas floristique de la Loire-Atlantique et de la Vandée. Etat et avenir d'un patrimoine. Tome 2. Cartes et commentaires. Société des Sciences Naturelles de l'Ouest de la France et Conservatoire Botanique National (Brest). Siloë, Brest.

Durka, W., 2002. Blüten- und Reproduktionsbiologie. Schrifthefte für Vegetationskunde. Bundesamt für Naturschutz, Bonn. 38, 133-175.

Eckardt, T., 1957. Vergleichende Studie über die Morphologieschen Beziehungen zwischen Fruchtblatt, Samenanlage und Blütenachse bei einigen Angiospermen. Neue Hefte zur Morphologie. Drittes Heft. Hermann Böhlaus Nachfolger, Weimar 3, 46-53.

Elger, A., Barrat-Segretain, M.-H., 2004. Plant palatability can be inferred from a single-date feeding trial. Funct. Ecol. 18, 483-488.

Elger, A., Barrat-Segretain, M.-H., Amoros, C., 2002. Plant palatability and disturbance level in aquatic habitats: an experimental approach using the snail Lymnea stagnalis (L.). Freschw. Biol. 47, 931-940.

Ellenberg, H., Weber, H.E., Düll, R., Wirth, V., Werner, W., Paulissen, D., 1992. Zeigerwerte von Pflanzen in Mitteleuropa. Zweite Auflage. Scripta Geobotanica. 18.

Engelmann, G., 1848. Echinodorus sp. In: Gray, A. (Ed.), A manual of the Botany of the Northern United States. Ivision, Blackeman, Taylor \& Co., Cambridge, p. 703.

Erwin, D.M., Stockey, R.A., 1989. Permineralized monocotyledons from Middle Eocene Princeton Chert (Allenby Formation) of British Columbia: Alismataceae. Can. J. Bot. 67, 2636-2645.

Eyres, G., Dufour, J.P., Hallifax, G., Sotheeswaran, S., Marriott, P.J., 2005. Identification of character-impact odorants in coriander and wild coriander leaves using gas chromatography-olfactormetry (GCO) and comprehensive two-dimensional gas chromatography-time-of-flight mass spectrometry (GC $\times$ GC-TOFMS). J. Separ. Sci. 28, 1061-1074.

Favarger, C., 1980. Hybridation et microevolution dans quelques groupes de phanérogames. In: Hybridation et systématique. Muséum National d'Histoire Naturelle, Paris. 
Fernandes, A., Garcia, J., Fernandes, R., 1948. Herborizaçoes nos dominios da fundaçao da Casa de Bragança I-Vendas Novas. Mem. Soc. Brot. 4, 5-89.

Fernandez Casas, J., 1978. Recuentos cromosomicos en plantas vasculares españolas (2). Saussurea 9, 45-50.

Fernandez-Alaez, C., Fernandez-Alaez, M., Becares, E., 1999. Influence of water level fluctuation on the structure and composition of the macrophyte vegetation in two small temporary lakes in the northwest of Spain. Hydrobiologia 415, 155-162.

Fernandez-Alaez, M., Fernandez-Alaez, C., Becares, E., 1999. Nutrient content in macrophytes in Spanish shallow lakes. Hydrobiologia 408/409, 317-326.

Figuerola, J., Green, A.J., 2002. Dispersal of aquatic organisms by waterbirds: a review of past research and priorities for future studies. Freshwater Biol. 47, 483-494.

Fischer, W., Kummer, V., Pötsch, J., 1995. Zur Vegetation des Feuchtgebietes internationaler Bedeutung (FIB) Untere Havel. Naturschutz und Landschaftspflege in Brandenburg $4 / 5,12-18$.

Franco, J.A., Afonso, M.L.R., 1994. Nova flora de Portugal, vol. 3, Fasciculo I. Cambridge University Press, Lisboa.

Fullana Montoro, J., 2001. Plan de protection de recursos hidricos de la zona humeda de Almenara. Varios (Castellon). Ministerio de Medio Ambiente. Oficina de planification hidrologica, Varios.

Gadella, T.W.J., Kliphuis, E., 1963. Chromosome numbers of flowering plants in the Netherlands. Acta Bot. Neerl. 12, 195-230.

Gamisans, J., 1991. La végétation de la Corse. In: Jeanmonod, D., Burdet, H.M. (Eds.), Compléments au prodrome de la flore Corse. Editions des Conservatoire et Jardin botanique de la Ville de Genève, Genève.

Gamisans, J., 1999. La végétation de la Corse. Edisud, Aix-enProvence.

Garbey, C., Murphy, K.J., Thiebaut, G., Muller, S., 2004. Variation in P-content in aquatic plant tissues offers an efficient tool for determining plant growth strategies along a resource gradient. Freshwater Biol. 49, 346-356.

Gaume, R., 1924. Aperçu sur quelques asociations végétales de la forêt d'Orléans (Loiret). Bull. Soc. Bot. France (quatrième série) 71, 1194-1199.

Glück, H., 1905. Biologische und morphologische Untersuchungen über Wasser- und Sumpfgewächse. Erster Teil: Die Lebensgeschichte der europäischen Alismaceen. Gustav Fischer, Jena.

Glück, H., 1906. Alismataceae. In: Kirchner, O., Loew, E., Schröter, C. (Eds.), Lebensgeschichte der Blütenpflanzen Mitteleuropas. Band I, Abteilung I. Eugen Ulmer, Stuttgart, pp. 584-648.

Gorczynski, L., 1922. Sur la situation climatique de la Pologne et sur son degree de continentalisme. Ciel et Terre. Bulletin de la Société Belge d'Astronomie, No. 11-12, Bruxelles.

Graber, A., 1924. La Flore des Gorges de l'Areuse et du Creux-du-Van ainsi que des regions environnantes. Mitteilungen aus dem Botanischen Museum der Universität Zürich. XCIX. Imprimerie Centrale, Neuchâtel.

Grillas, P., Gauthier, P., Yavercovski, N., Perennou, C., 2004. Mediterranean temporary pools, vol. 2. Station biologique de la Tour du Valat. Le Sambuc, Arles.
Grime, J.P., 1977. Evidence for the existence of three primary strategies in plants and its relevenace to ecological and evolutionary theory. Am. Nat. 111, 1169-1194.

Grootjans, A.P., Geelen, H.W.T., Jansen, A.J.M., Lammerts, E.J., 2002. Restoration of coastal dune slacks in Netherlands. Hydrobiologia 478, 181-203.

Guillen, A., Laínz, M., Lastra, J.J., Mayor, M., 1998. Algo acerca de Baldellia alpestris (Coss.) M. Laínz (Alismataceae): número cromosomático, puntualizaciones a la descripción original y un par de citas notables de Asturias. Anal. Jard. Bot. Madrid 52, 392-393.

Gutierrez-Yurita, P.J., Sancho, G., Bravo, M.A., Baltanás, A., Montes, C., 1998. Diet of the Red swamp crayfish (Procambarus clarkii) in natural ecosystems of the Doñana National Park temporary fresh-water marsh (Spain). J. Crust. Biol. 18, 120-127.

Hadziablahovič, S., 2005. Contribution to the flora of Montenegro and FR Yugoslavia. Hacquetia 4, 103-110.

Haeupler, H., Schönfelder, P., 1988. Atlas der Farn-und Blütenpflanzen der Bundesrepublik Deutschland. Eugen Ulmer, Stuttgart.

Hagerup, O., 1944. Notes on some boreal polyploids. Hereditas 30, 152-160.

Haggard, K.K., Tiffney, B.H., 1997. The flora of the Early Miocene Brandon Lignite, Vermont, USA. VIII. Caldesia (Alismataceae). Am. J. Bot. 84, 239-252.

Haynes, R.R., Les, D.H., Holm-Nielsen, L.B., 1998. Alismataceae. In: Kubitzki, K. (Ed.), The Families and Genera of Vascular Plants. Springer, Berlin-Heidelberg.

Hess, H.E., Landolt, E., Hirzel, R., 1977. Flora der Schweiz und angrenzender Gebiete. Band I. Birkhäuser, Basel.

Hohenester, A., Welss, W., 1993. Exkursionsflora für die Kanarischen Inseln mit Ausblicken auf ganz Makaronesien. Eugen Ulmer, Stuttgart.

Hulten, E., Fries, M., 1986. Atlas of North European vascular plants: north of the Tropic of Cancer. Koeltz Scientific Books, Königstein.

Ingelög, T., Thor, G., Hallingbäck, T., Andersson, R., Aronsson, M., 1991. Floravard i jordbrukslandskapet. Skyddsvärda växter. SBT, Lund.

Jacobson, A., 2003. Diversity and phylogeography in Alisma (Alismataceae), with emphasis on Northern European taxa. Scripta Academica Lundensia. Ph.D. Thesis. University of Lund, Sweden.

Jäger, E.J., 1968. Die pflanzengeographische Ozeanitätsgliederung der Holarktis und die Ozeanitätsbindung der Pflanzenareale. Feddes Rep. 79, 157-335.

Jahandiez, E., Maire, R., 1931. Catalogue des plantes du Maroc. Tome premier. Imprimerie Minerva, Alger.

Jain, S.K., 1976. The evolution of inbreeding in plants. Ann. Rev. Ecol. Syst. 7, 469-495.

Janssen, T., Bremer, K., 2004. The age of major monocot groups inferred from $800+r b c L$ sequences. Botan. J. Linn. Soc. 146, 385-398.

Jeanmonod, D., Burdet, H.M., 1989. Notes et contributiones à la Flore de Corse. IV. Candollea 44, 344-345.

Jeanmonod, D., Burdet, H.M. (Eds.), 1991. Compléments au Prodrome de la Flore Corse. Editions des Conservatoire et Jardin botaniques de la Ville de Genève, Genève. 
Jones, R.A., 2006. Creeping water-plantain (Dyfr lyriad ymlusgawl), Baldellia ranunculoides subsp. repens (Lam.) À. Löve \& D. Löve in Wales. In: Leach, S.J., Page, C.N., Peytoureau, Y., Sanford, M.N. (Eds.), Botanical links in the Atlantic arc. BSBI Conference Report No. 24, pp. 311-319.

Jundzill, B.S., 1791. Opisanie roslin w prowincyi W.X.L. naturalnie rosnacych wedlug ukladu Linneusza. Wilno.

Käsermann, Ch., Moser, D., 1999. Merkblätter Artenschutz Blütenpflanzen und Farne. BUWAL, Bern.

Kennedy, M.P., Murphy, K.J., 2004. Indicators of nitrate in wetland surfaces and soil-waters: interactions of vegetation and environmental factors. Hydr. Earth Syst. Sci. 8, 663-672.

Kern, J., Reichgelt, T., 1950. Over enige kritische planten van onze flora. Nederlandsch Kruidkundig Archief 57, 244-261.

Krausch, H.-D., 1985. Ozeanische Florenelemente in aquatischen Pflanzengesellschaften der D.D.R. Vegetatio 59, 193-198.

Krausch, H.-D., 1996. Farbatlas, Wasser- und Uferpflanzen. Eugen Ulmer, Stuttgart.

Lainz, M., 1967. Aportaciones al conocimiento de laflora allega. V. Anal. Inst. Forest. Invest. 12, 1-51.

de Lamarck, J.-B., 1786. Encyclopédie méthodique. Botanique, vol. 2. Chez Pankoucke, Paris, p. 515.

Landolt, E., 1977. Ökologische Zeigerwerte zur Schweizer Flora. Veröffentlichungen des Geobotanischen Instituts ETH Zürich 64, 1-208.

Lawalrée, A., 1959. Baldellia repens (Lamk.) van Ooststroom en Belgique. Bull. Jard. Bot. Etat Brux. 29, 7-14.

Les, D.H., Cleland, M.A., Waycott, M., 1997. Phylogenetic studies in Alismatidae, II: Evolution of marine Angiosperms (Seagrasses) and Hydrophily. Syst. Bot. 22, 444- 463.

Les, D.H., Crawford, D.J., Kimball, R.T., Moody, M.L., Landolt, E., 2003. Biogeography of discontinuously distributed hydrophytes: a molecular appraisal of intercontinental disjunctions. Int. J. Plant Sci. 164, 917-932.

Lewis, W.H., 1962. Aneusomaty in aneuploid populations of Claytonia virginica. Am. J. Bot. 49, 918-928.

Lid, J., Lid, D.T., 2005. In: Elven, R. (Ed.), Norsk flora, seventh ed. Det Norske Samlaget, Oslo.

Lindblad, R., Ståhl, B., 1989. Krypfloka (Apium inundatum) och flocksvalting (Baldellia ranunculoides) i norra Halland (SW Sweden). Svensk Bot. Tidskr. 83, 211-217.

Lindblad, R., Ståhl, B., 1990. Revsvalting, Baldellia repens, i Norden. Svensk Bot. Tidskr. 84, 253-258.

Linnaeus, C., 1753. Species plantarum. Impensis Laurentii Salvii, Holmiae (Stockholm), p. 343.

Loucougaray, G., Bonis, A., Bouzillé, J.B., 2004. Effects of grazing by horses and/or cattle on the diversity of coastal grasslands in western France. Biol. Conserv. 116, 59-71.

Löve, À., Löve, D., 1944. Cyto-taxonomical studies on boreal plants. III. Some new chromosome numbers of Scandinavian plants. Ark. f. Bot. 12 (31 A), 1-22.

Löve, À., Löve, D., 1961a. Chromosome numbers of Central and Northwest European plant species. Opera. Bot. 5, $1-581$.

Löve, À., Löve, D., 1961b. Some nomenclatural changes in the European flora I. Species and supraspecific categories. Bot. Not. 114, 33-47.

MacArthur, R., Wilson, E.O., 1967. The Theory of Island Biogeography. Princeton University Press, Princeton.
Mai, D.H., Walther, H., 1988. Die pliozänen Floren von Thüringen, Deutsche Demokratische Republik. Quartärpaläontologie 7, 55-297.

Maire, R., 1952. Flore de l'Afrique du Nord (Maroc, Algérie, Tunisie, Tripolitaine, Cyrénaïque et Sahara). Paul Lechevalier, Paris.

Manning, J.C., Goldblatt, P., 2001. A synoptic review of Romulea (Iridaceae: Crocoideae) in sub-Saharan Africa, the Arabian Peninsula and Socotra including new species, biological notes, and a new infrageneric classification. Adansonia (sér. 3) 23, 59-108.

Maremmani, A., Bedini, S., Matosevic, I., Tomei, P.E., Giovannetti, M., 2003. Type of mycorrhizal associations in two coastal nature reserves of the Mediterranean basin. Mycorrhiza 13, 33-40.

Markgraf, F., 1981. Alismataceae. In: Hegi, G. (Ed.), Illustrierte Flora von Mitteleuropa. Band I, Teil 2, Dritte Auflage. Paul Parey, Berlin, pp. 154-171.

Meade, R., Wheeler, B.D., 1990. Illtyd Pools, Brecon: description and conservation. New Phytol. 115, 187-199.

Meusel, H., Jäger, E., Weinert, E., 1992. Vergleichende Chorologie der Zentraleuropäischen Flora, vol. 1-3. Gustav Fischer, Jena.

Meyer, J., 1932. Beiträge zur Anatomie der Alismataceen. Beih. Bot. Centralbl. 49, 309-368.

Micheli, M., 1881. Alismataceae. In: de Candolle, A.C. (Ed.), Sites au Prodromus systematis naturalis regni vegetabilis. Monographiae Phanerogamarum, vol. 3. Paris.

Molina Abril, J.A., Pizarro, J., Sardinero, S., Galan de Mera, A., 1994. Baldellia ranunculoides subsp. cavanillesii, subsp. nov. algunas aclaraciones sobre Alisma tangerina Pau (Alismataceae). Anal. Jard. Bot. Madrid 52, 120-122.

Moreira, I., Ferreira, T., Monteiro, A., Catarino, A., Vasconçelos, T., 1999. Aquatic weeds and their management in Portugal: insights and the international context. Hydrobiologia 415, 229-234.

Moreno Saiz, J.C., Sainz Ollero, H., 1992. Atlas corologico de las Monocotiledoneas endemicas de la poninsila Iberica y Baleares. Bases para una politica de conservacion. Colleccion Tecnica. Icona, Madrid.

Moser, D.M., Gygax, A., Bäumler, B., Wyler, N., Palese, R., 2002. Liste rouge des fougères et plantes à fleurs menacées de Suisse. BUWAL, Bern.

Mouterde, P.S.J., 1966. Nouvelle flore du Liban et de la Syrie. Editions de l'Imprimerie Catholique, Beyrouth.

Mühlberg, H., 2000. Beiträge zur Kenntnis der Gattung Echinodorus L.C. Rich. 1. Die Blütenstände. Schlechtendalia 4, 41-48.

Mühlberg, H., 2004. Beiträge zur Kenntnis der Gattung Echinodorus. 2. Echinodorus ovalis. Schlechtendalia 12, 95-100.

Murphy, K.J., 2002. Plant communities and plant diversity in softwater lakes of northern Europe. Aquat. Bot. 73, 287-324.

Nielsen, U.N., Riis, T., Brix, H., 2006. The effect of weed cutting on Luronium natans. Aquat. Conserv: Mar. Freshwater Ecosyst. 16, 409-417.

Noest, V., 1991. Simulated impact of sea level rise on phreatic level and vegetation of dune slacks in the Voorne dune area (The Netherlands). Lands Ecol. 6, 89-97. 
Oberdorfer, E. (Ed.), 1977. Süddeutsche Pflanzengesellschaften. Teil I. Gustav Fischer, Stuttgart.

Palmer, M.A., Roy, D.B., 2001. A method for estimating the extent of standing fresh water of different trophic states in Great Britain. Aquat. Conserv.: Mar. Freshwater Ecosyst. 11, 199-216.

Palmgren, O., 1943. Chromosome numbers in angiospermous plants. Bot. Notiser. 1939, 348-352.

Parlatore, F., 1854. Nuovi generi e nuove specie di piante monocotiledoni. 57.

Passarge, H., 1999. Pflanzengesellschaften Nordostdeutschland 2. II. Helocyperosa und Caespitosa. J. Cramer, Stuttgart.

Pastor, J., 1983. Numeros cromosomicos para flora española. Lagascalia 12, 117-119.

Petersen, J., 2000. Die Dünentalvegetation der WattenmeerInseln in der südlichen Nordsee. Eine Pflanzensoziologische und ökologische Vergleichuntersuchung unter Berücksichtigung von Nutzung und Naturschutz. Husum Druck- und Verlagsgesellschft, Husum.

Pianka, E.R., 1970. On $\mathrm{r}$ and K selection. Am. Nat. 104, 592-597.

Pietsch, W., 1985. Chorologische Phänomene in Wasserpflanzengesellschaften Mitteleuropas. Vegetatio 59, 97-109.

Piotrowska, H., 1966a. Rosliny naczyniowe wyspy Wolina i poludniowo-wschodniego Uznamu. Pozn. Tow. Przyj. Nauk, Prace Komisji Biologicznej 30, 1-282.

Piotrowska, H., 1966b. Stosunki geobotaniczne wyspy Wolina i poludniowo-wachodniego Uznamu. Monographiae Botanicae 22. PWN, Warszawa.

Polhill, R.M., Raven, P.H., 1981. Advances in Legume Systematics. Royal Botanical Gardens, Kew.

Posluszny, U., Charlton, W.A., Les, D.H., 2000. Modularity in helobial flowers. In: Wilson, K.L., Morrison, D.A. (Eds.), Monocots: Systematics and Evolution. CSIRO, Melbourne.

Pott, R., 1995. Die Pflanzengesellschaften Deutschlands, second ed. Eugen Ulmer, Stuttgart.

Pottier-Alapetite, G., 1958. Interet phytogéographique de la region de Sedjenane en Tunisie. Plant Ecol. 8, 176-180.

Preston, C.D., Croft, J.M., 2001. Aquatic plants in Britain and Ireland. Harley Books, Colchester, Essex.

Preston, C.D., Pearman, D.A., Dines, T.D., 2003. New Atlas of the British and Irish Flora. Oxford University Press, Oxford.

Punt, W., Reumer, J.W., 1981. The northwest European pollen flora. 22. Alismataceae. Rev. Palaeobot. Palynol. 33, $27-44$.

Quezel, P., Santa, S., 1962. Nouvelle flore de l'Algérie et des régions désertiques méridionales. Editions du Centre National de la Recherche Scientifique, Paris.

Raabe, U., van de Weyer, K., 1998. Effizienzkontrolle von Artenschutzgewässern in NRW. Floristische Aspekte. LÖBF Mitteilungen 3, 77-89.

Raunkiaer, C., 1895. De danske blomsterplantens naturhistorie. Gyldendalske, København.

Ray, P.M., Chisaki, H.F., 1957. Studies on Amsinckia. II. Aneuploid diversification in the Muricatae. Am. J. Bot. 44, 545-554.

Reid, E.M., 1923. Nouvelles recherches sur les graines du Pliocène inférieur du Ponz-du-Gail. Bull. Soc. Géeol. France. Sér. IV 23, 308-355.

Rich, T.C.G., Nicholls-Vuille, F.-L., 2001. Taxonomy and distribution of European Damasonium (Alismataceae). Edinb. J. Bot. 58, 45-55.
Rikli, M., 1943. Das Pflanzenklied der Mittelmeerländer. Band I-III. Hans Huber, Bern.

Rivas-Martinez, S., Costa, M., Castroviejo, S., Valdes, E., 1980. Vegetacion de Doñana (Huelva, España). Lazaroa 2, 5-189.

Rivas-Martinez, S., Diaz, T.E., Fernandez-Gonzalez, F., Izco, J., Loidi, J., Lousa, M., Penas, A., 2002. Vascular plant communities of Spain and Portugal. Addenda to the syntaxonomical checklist of 2001. Itinera Geobotan. 15, 5-922.

Rodriguez, C.F., Becares, E., Fernandez-Alaez, M., Fernandez-Alaes, C., 2005. Loss of biodiversity and degradation of wetlands as a result of introducing exotic crayfish. Biol. Invas. 7, 75-85.

Rodriguez-Oubina, J., Ortiz, S., 1991. Luronium natans (Alismataceae) in the Iberian Peninsula. Willdenowia 21, 77-80.

Rodwell, J.S., Pigott, C.D., Ratcliffe, D.A., Malloch, A.J.C., Birks, H.J.B., Proctor, M.C.F., Shimwell, D.W., Huntley, J.P., Radford, E., Wigginton, M.J., Wilkins, P., 1991. British Plant Communities, vol. 1-5. Cambridge University Press, Cambridge.

Roelofs, J.G.M., 1983. Impact of acidification and eutrophication on macrophyte communities in soft waters in the Netherlands. I. Field observations. Aquat. Bot. 17, 139-155.

Roelofs, J.G.M., 2002. Soft-water macrophytes and ecosystems: why are these so vulnerable to environmental changes? Aquat. Bot. 73, 285-286.

Roelofs, J.G.M., Schuurkes, J.A.A.R., Smits, A.J.M., 1984. Impact of acidification and eutrophication on macrophyte communities in soft waters in the Netherlands. II. Experimental studies. Aquat. Bot. 18, 389-411.

Romero, M.I., Rubinos, M., Ramil, P., 2003. Luronium natans, a rare species in the Iberian peninsula. Belg. J. Bot. 137, 85-90.

Rye, B.L., James, S.H., 1992. The relationship between dysploidy and reproductive capacity in Myrtaceae. Aust. J. Bot. 40, 829-848.

Sandsten, H., 2003. Vattenäxter i skanska sjöar - en jämförelse mellan 1970-telet och 2002. Länsstyrelsen i Skane län, Malmö.

Santamaria, L., 2002. Why are most aquatic plants widely distributed? Dispersal, clonal growth and small-scale heterogeneity in a stressful environment. Acta Oecol. 23, 137-154.

Sardinero Roscales, S., 1994. Etudio de la vegetation y de la flora del Macizo Occidental de la Sierra de Gredos (Sistema Central, Espana). Ph.D. Thesis. Faculty of Pharmacy, Departement of Botany II, University of Madrid.

Schäfer, H., 2002. Chorology and diversity of the Azorean flora. Part II. Commented checklist of the Azorean Flora. Distribution atlas of Flores, Faial and Santa Maria. Ph.D. Thesis, Institute of Botany, University of Regensburg.

Schäfer, H., 2003. Chorology and diversity of the Azorean flora. Dissertationes Botanicae. Band 374. J. Cramer, Stuttgart.

Schäfer, H., 2005. Flora of the Azores - a Field Guide, second ed. Margraf Publishers, Weikersheim. 
Schmeil, O., Fitschen, J., 1993. Flora von Deutschland und angrenzenden Ländern. Quelle Meyer, Wiebelsheim.

Schoof-van Pelt, M.M., 1973. Littorelletea - a study of the vegetation of some amphiphytic communities of Western Europe. Stichting Studentenpers, Nijmegen.

Schotsman, H.D., 1970. Contribution à la caryologie des angiospermes de la Sologne et du Val de Loire. II. Bul. Centr. Etudes Rech. Sci. 8, 199-255.

Schubert, R., Hilbig, W., Klotz, S., 1995. Bestimmungsbuch der Pflanzengesellschaften Mittel- und Nordostdeutschlands. Gustav Fischer, Stuttgart.

Selvi, F., Bigazzi, M., 2002. Chromosome studies in Turkish species of Nonea (Boraginaceae): the role of polyploidy and descending dysploidy in the evolution of the genus. Edinb. J. Bot. 59, 405-420.

Serbanescu-Jitariu, G., 1973. Beobachtungen am Gynözeum, an der Frucht und über die Keimung bei Echinodorus ranunculoides (L.) Engelm. Revue Roumaine de Biologie. Série de Botanique 18, 313-318.

Silvestre, S., 1993. Numeros cromosomaticos para la flora Española. Numeros 643-663. Lagascalia 17, 151-160.

Smiley, C.J., Rember, W.C., 1985. Composition of the miocene Clarkia flora. In: Smiley, C.J. (Ed.), Late Cenozoic History of the Pacific Northwest. Pacific division of the American Association for the Advancement of Science, San Francisco, CA, pp. 95-112.

Smith, J.E., 1828. English Botany, second ed. Longman, Rees, Orme Brown \& Green, London.

Smolders, A.J.P., Lucassen, E.C.H.E.T., Roelofs, J.G.M., 2002. The isoetid environment: biogeochemistry and threats. Aquat. Bot. 73, 325-350.

Stant, M.Y., 1963. Anatomy of the Alismataceae. J. Linn. Soc. Bot. 59, 1-42.

Strother, J.L., Brown, L.E., 1988. Dysploidy in Hymenoxys texana (Compositae). Am. J. Bot. 75, 1097-1098.

Szafer, W. (Ed.), 1959. Szata roslinna Polski. Tom 1 \& 2. Panstwowe Wydawnictwo Naukowe, Warszawa.

Tomlinson, P.B., 1982. Helobiae (Alismatidae), including the seagrasses. In: Metcalfe, C.R. (Ed.), Anatomy of the Monocotyledons. Clarendon Press, Oxford.

Triest, L., 1991a. Enzyme polymorphism and its relationships to biological features in aquatic plants (Including a comparison with terrestrial plants). In: Triest, L. (Ed.), Isozymes in water plants. Opera Bot. Belg. 4, pp. 201-240.

Triest, L., 1991b. Conservation of genetic diversity in water plants. In: Triest, L. (Ed.), Isozymes in water plants. Opera. Bot. Belg. 4, 241-258.

Triest, L., Vuille, F.-L., 1991. Isozyme variation in several seed collections and hybrids of Baldellia (Alismataceae). In: Triest, L. (Ed.), Isozymes in water plants. Opera Bot. Belg. 4, 37-48.

Tüxen, R., 1937. Mitteilungen der Floristisch-soziologischen Arbeitsgemeinschaft in Niedersachsen 3, 241-258.

Uchiyama, H., 1989. Karyomorphological studies on some taxa of the Helobiae. J. Sci. Hiroshima Univ. Ser. B Divis. 2 (Botany) 22, 271-352.

Valdes, B., Talavera, S., Fernandez-Galiano, E. (Eds.), 1987. Flora vascular de Andalucia Occidental. Part 3. Ketres Editora, SA, Barcelona. van Ooststroom, S.J., 1956. Baldellia repens. In: Heukels, H., van Ooststroom, S.J. (Eds.), Flora van Nederland, 14th ed. P. Noordhoff, Groningen.

van Rompaey, E., Delvosalle, L., 1972. Atlas de la flore belge et luxembourgeoise. Jardin Botanique National de Belgique, Bruxelles.

Vangjeli, L. (Ed.), 2000. Flore de l'Albanie. vol. 4. Academie des Sciences de la Republique d'Albanie. L'Institute des Recherches Biologiques, Tirana - Skhenca.

Vangjeli, J., Ruci, B., Mullaj, A., 1995. Libri i kuq, bimet e kercenuara dhe te rralla te Shqiperise (Red data book of threatened and rare plants species of Albania). Akademia e Shkencave/Instituti i Kerkimeve Biologike (Academy of Science-Albania, Institute of Biological Research), Tirane.

Vasconçellos, J.C., 1970. Novas combinaçoes nomenclaturais de plantas da flora Portuguesa. Bol. Soc. Broteriana, Ser. 2 44, 81-83.

Velayos, M., Carrasco, M.A., Cirujano, S. (Eds.), 1989. Las lagunas del Campo de Calatrava (Ciudad Real), Bot. Complutensis (Edit. Universidad Complutense) 14, 9-50.

Vogt, R., Oberprieler, C., 1994. Chromosome numbers of North African phanerogams. IV. Candollea 49, 549-570.

Vuille, F.-L., 1987. Reproductive biology of the genus Damasonium (Alismataceae). Plant Syst. Evol. 157, 63-71.

Vuille, F.-L., 1988. The reproductive biology of the genus Baldellia (Alismataceae). Plant Syst. Evol. 159, 173-183.

Walstad, D., 1999. Ecology of the Planted Aquarium. Echinodorus Publishing, Chapel Hill.

Walter, H., Straka, H., 1970. Arealkunde, 2nd ed. Ulmer, Stuttgart.

Wassen, M.J., Venterink, H.O., Lapshina, E.D., Tannenberger, F., 2005. Endangered plants persist under phosphorus limitation. Nature 437, 547-560.

Watson, L., Dallwitz, M.J., 1992. The families of flowering plants: descriptions, illustrations, identification, and information retrieval. Version: 23rd October 2005. Retrieved from $\langle$ http://delta-intkey.com $\rangle$.

Weber, C.A., 1893. Über die diluviale Vegetation von Klinge in Brandenburg und über ihre Herkunft. Englers Botan, Jahresb. Bd. 17. Beiblatt 40.

Weeda, E.J., Westra, R., Westra, Ch., Westra, T., 1991. Nederlandse oekologische flora. Wilde planten en hun relaties, vol. 4. IVN, VARA \& VEWIN, Hilversum.

Welk, E., 2001. Arealkundliche Analyse und Bewertung der Schutzrelevanz seltener und gefährdeter Gefässpflanzen Deutschlands. Ph.D. Thesis, Martin-Luther-Universität Halle-Wittenberg, Halle/Saale.

Wells, S.H., 1979. Self fertilization: advantageous or deleterious? Evolution 33, 252-255.

Wheeler, B.D., 1980. Plant communities of rich-fen systems in England and Wales: I. Introduction. Tall sedge and reed communities. J. Ecol. 68, 365-395.

Wichmann, M., Staudler, H., Haase, P., Burkart, M., 2000. Naturschutzfachliche Bewertung einer Pflegemassnahme mit Galloways am Südufer des Gülper Sees unter Einfluss hydrologischer Dynamik. Naturschutz und Landschaftspflege in Brandenburg 9, 23-32. 
Wilder, G.J., 1975. Phylogenetic trends in the Alismataceae (Monocotyledoneae). Bot. Gaz. 136, 159-170.

Willby, N.J., Eaton, J.W., 1993. The distribution, ecology and conservation of Luronium natans (L.) Raf. In Britain. J. Aquat. Plant Manage. 31, 70-76.

Wilson, K.L., Morrison, D.A. (Eds.), 2000. Monocots. Systematics and Evolution. CSIRO, Collingwood, Australia.
Wojciechowski, M.F., Sanderson, M.J., Baldwin, B.G., Donoghue, M.J., 1993. Monophyly of aneuploid Astragalus (Fabaceae): evidence from nuclear ribosomal DNA internal transcribed spacer sequences. Am. J. Bot. 80, 711-722.

Zajac, A., Zajac, M. (Red.), 2001. Atlas rozmieszczenia roslin naczyniowych w Polsce (ATPOL). Inst. Bot. UJ, Kraków. 
Supplementary material: the following sources have been used for the new distribution map of B. ranunculoides s.l. (Fig. 7) and B. ranunculoides subsp. repens (Fig. 8):

\section{Sources with distribution maps:}

\section{B. ranunculoides subsp. ranunculoides:}

Global distribution: Cook, 1983; Hulten and Fries, 1986; Meusel et al., 1992; de Bolos and Vigo, 2003. Alpine region: Aeschimann et al., 2004. Central Europe: Müller-Stoll et al., 1962. Scandinavia (Denmark, Norway, Sweden): Hulten, 1971. Countries: Albania: Vangjeli et al., 1995. Belgium: Lawalrée, 1959; Berten, 1993; van Rompaey and Delvosalle, 1972. Croatia: http://hirc.botanic.hr. Denmark: Hulten, 1971. France: Dupont, 1990; http://inpn.mnhn.fr; Hautes-Alpes: www.florealpes.com; Chas, 1994; la Loire-Atlantique et la Vendée: Dupont, 2001; l'Ile-de-France: Arnal, 1996. Germany: www.floraweb.de; West: Haeupler and Schönfelder, 1988; East: Benkert et al., 1988; Schleswig-Holstein and Hamburg: Raabe et al., 1987; Mecklenburg: Pankow and Rattey, 1963; Havelland: Fischer et al., 1995. Greece: Bazos and Yannitsaros, 2001. Holland, North Brabant: Cools, 1989. Ireland: Preston et al., 2003; Preston and Croft, 2001; www.searchnbn.net. Italy: Pignatti, 1984. Northern Ireland: Preston et al., 2003; Preston and Croft, 2001; www.searchnbn.net; www.habitats.org.uk. Norway: Hulten, 1971. Poland: Czeczott, 1926; Zajac and Zajac, 2001. Spain: www.programanthos.org; Catalunia: de Bolos and Vigo, 2003; Andalucia: Valdes et al., 1987. Sweden: Ingelög, 1991; Aronsson, 1999; Hulten, 1971; Lindblad and Ståhl, 1990. Switzerland: Käsermann and Moser, 1999; Welten and Sutter, 1982; www.wsl.ch (Webflora). United Kingdom: Preston and Croft, 2001; Preston et al., 2003; www.searchnbn.net.

B. ranunculoides subsp. repens:

Belgium: Lawalrée, 1959; Berten, 1993; van Rompaey and Delvosalle, 1972. Holland, North Brabant: Cools, 1989. France: http://inpn.mnhn.fr. Norway: Hulten, 1971. Sweden: Ingelög, 1991; Aronsson 1999; Lindblad and Ståhl 1990.

\section{Further sources with distribution description:}

Literature: Ascherson and Graebner, 1913; Bagdonaite et al., 1963; Barcelo, 1977; Battandier and Trabut, 1895; Battandier and Trabut, 1905; Benabid, 2000; Bonnet and Barratte, 1896; Braun-Blanquet, 1953; Charpin and Salanon, 1985; Christiansen and Anthon, 1958; Colling, 2005; Colmeiro, 1889; Coutinho, 1939; Cuenod et al., 1954; Dandy, 1980; Dimopoulos et al., 2005; Domač, 1994; Doogue et al., 1998; Dupont, 1962; Franco and Afonso, 1994; Gamisans, 1999; Graber, 1924; Hadziablahovič, 2005; de Halacsy, 1904; Hohenester and Welss, 1993; Jahandiez and Maire, 1931; Jeanjean, 1961; Jeanmonod and Burdet, 1989; Jeanmonod and Burdet, 1991; Jundzill, 1791; de Langhe et al., 1973; Lindblad and Ståhl, 1989; Maire, 1952; Markgraf, 1981; Martinčič et al., 1999; Mayer, 1952; Mikkelsen, 1943; Moeslund et al. 1990; Mouterde, 1966; Piotrowska, 1966a, 1966b; Polunin and Smythies, 1977; Polunin, 1980; Pottier-Alapetite, 1958; Prasse et al., 2001; Quezel and Santa, 1962; Sarika-Hatzinikolaou et al., 1996; Schäfer, 2002; Schäfer, 2003; Schäfer, 2005; Stoltze, 1998; Szafer, 1959; Vangjeli et al., 1995; Weeda et al., 1991; de Wildeman and Durand, 1899; Zarzycki et al., 1992. Websites: Albania: www.medwetcoast.com; Balearic Islands: www.caib.es, www.uib.es; Belgium: www.instnat.be, http://mrw.wallonie.be; Croatia: www.coe.int; France: http://natura2000.environnement.gouv.fr, http://natura2000.bretagne.ecologie.gouv.fr; Germany: www.loebf.nrw.de; Ireland: www.habitas.org.uk; Italy: www.regione.emilia_romagna.it, www.zoneumidetoscane.it; Norway: www.environment.no; Spain: http://biodiver.bio.ub.es, www.globalbioclimatics.org; Sweden: www.artdata.slu.se; Turkey: www.wwf.org.tr; United Kingdom: www.jncc.gov.uk

References (only those not mentioned in the main text)

Aeschimann, D., Lauber, K., Moser, D.D., Theurillat, J.-P., 2004. Flora alpina. Haupt, Bern.

Arnal, G., 1996. Plantes protegées de l’Ile-de-France. Biotop, Paris.

Bagdonaite, A., Galinis, V., Jankeviciene, R., Lekavicius, A., Natkevicaité-Ivanauskiene, M., Pipinys, J., Purvinas, E., Ribokaite, R., Snarskis, P., Stancevicius, A., Sarkiniene, I., 1963. Lietuvos TSR Flora II. Valstybine, Plitines ir Mokslines literaturos Leidykla, Vilnius.

Benabid, A., 2000. Flore et écosystèmes du Maroc, évaluation et préservation de la biodiversité. Ibis Press, Paris and Kalila Wa Dimma, Rabat.

Berten, R., 1993. Limburgse plantenatlas, pteridopfyten en spermatofyten. Likona, Limburg.

Christiansen, M., Anthon, H., 1958. Danmarks vilde planter. Branner og Korch, København.

Colling, G., 2005. Red list of the vascular plants of Luxembourg. Ferrantia. Volume 42. Travaux scientifiques du Musée national d'histoire naturelle, Louxembourg.

Colmeiro, M., 1889. Enumeracion y revision de las plantas de la Peninsula Hispano-Lusitana é Isles Baleares. Tomo V, Monocotiledoneas y criptogamas. Imprenta de la Viuda é Hija de Fuentenebro, Madrid.

Consonni, G., 1999. La flora insubrica (Corni di Canzo, Monte Barro, Resegone, Artavaggio, Grigne, Monte Legnone, Pian di Spagna, Piano del Tivano). C. Nani, Lipomo. 
Coutinho, A.I.P., 1939. Flora de Portugal (Plantas vasculares) - Disposta em chaves dicotomicas. 2a Ediçao. Bertrand (Irmaos) Ltd., Lisboa.

Cuenod, A., Pottier-Alapetite, G., Labbe, A., 1954. Flore analytique et synoptique de la Tunisie. Cryptogammes vasculaires, gymnospermes et monocotyledones. Office de l'experimentation et de la vulgarisation agricoles de Tunisie, Tunis.

Domač, R., 1994. Flora Hrvatske - Priručnik za odredivanje bilja. Skolska Knjiga, Zagreb.

Doogue, D., Nash, D., Parnell, J., Reynolds, S., Jackson, P.W., 1998. Flora of County Dublin. The Dublin Naturalists’ Field Club. Royal Dublin Society, Dublin.

Fischer, W., Kummer, V., Pötsch, J., 1995. Zur Vegetation des Feuchtgebietes internationaler Bedeutung (FIB) Untere Havel. Naturschutz und Landschaftspflege in Brandenburg. 4/5, 12-18.

de Halacsy, E., 1904. Conspectus florae Graecae. Volumen III. Sumptibus Guilelmi Engelmann, Leipzig.

Hansen, A., Sunding, P., 1979. Flora of Macaronesia. Checklist of vascular plants (2nd revised edition). Sommerfeltia 17. Botanisk hage og Museum, Universitet i Oslo, Oslo.

Hulten, E., 1971. Atlas of the distribution of vascular plants in Northwestern Europe. Generalstabens Litografiska Anstalts Förland, Stockholm.

Jeanjean, A.F., 1961. Catalogue des plants vasculaires de la Gironde. Actes de la Société Linnéenne de Bordeaux (Tome 99), Bordeaux.

de Langhe, J.-E., Delvosalle, L., Duvigneaud, J., Lambinon, J., Vanden Berghen, C., 1973. Nouvelle flore de la Belgique, du Grand-Duché de Louxembourg, du Nord de la France et des régions voisines. Edition du Patromoine du Jardin botanique national de Belgique, Bruxelles.

Martinčič, A., Wraber, T., Jogan, N., Ravnik, V., Podobnik, A., Turk, B., Vreš, B., 1999. Mala flora Slovenije. Tehniška založba Slovenje, Ljubljana.

Mayer, E., 1952. Seznam praprotnic in cvetnic Slovenskega ozemlija (Verzeichnis der Farn- und Blütenpflanzen des Slowenischen Gebietes). Slovenska Akademija Znanosti in Umetnosti. Classis IV: Historia Naturalis et Medicina. Opera 5, Ljubljana.

Mikkelsen, V.M., 1943. Udbredelsen af Juncaginaceae, Alismataceae og Hydrocharitaceae i Danmark. Bot. Tidsskr. 47, 65-93.

Moeslund, B., Løjtnant, B., Mathiesen, H., Mathiesen, L., Pedersen, A., Thyssen, N., Schou, J.C., 1990. Danske vandplanter. Vejledning i bestemmelse af planter i søer og vandløb. Miljønyt 2, 1-192.

Müller-Stoll, W.R., Fischer, W., Krausch, H.D., 1962. Verbreitungskarten brandenburgischer Leitpflanzen. 4. Reihe. Wiss. Z. Päd. Hochsch. Potsdam. 7, 95-150.

Pankow, H., Rattey, F., 1963. Verbreitungskarten zur Pflanzengeographie Mecklenburgs II. Reihe. Wissenschaftliche Zeitschrift der Ernst-Moritz-Arndt-Universität Greifswald 12. Math.-Nat. R. 5/6, 359376.

Pignatti, S., 1984. Flora d’Italia. Edagricole, Bologna.

Polunin, O., Smythies, B.E., 1977. Guía de campo de las flores de España, Portugal y Sudoeste de Francia. Omega, Barcelona.

Polunin, O., 1980. Flowers of Greeece and the Balkans, a field guide. Oxford University Press, Oxford.

Prasse, R., Ristow, M., Klemm, G., Machatzi, B., Raus, T., Scholz, H., Stohr, G., Sukopp, H., Zimmermann, F., 2001. Liste der wildwachsenden Gefässpflanzen des Landes Berlin mit Roter Liste. Senatsverwaltung für Stadtentwicklung. Der Landesbeauftragte für Naturschutz und Landschaftspflege, Berlin.

Raabe, E.-W., Dierssen, K., Mierwald, U., 1987. Atlas der Flora Schleswig-Holsteins und Hamburgs. Wachholtz, Neumünster.

Sarika-Hatzinikolaou, M., Koumpli-Sovantzi, L., Yannitsaros, A., 1996. The vascular flora of Lake Kalodhiki (Ipiros, NW Greece). Webbia 50, 223-236.

Stoltze, M., 1998. Gulliste 1997 over planter og dyr i Danmark. Miljø-og Energiministeriet, Danmarks Miljøundersøgelser, Skov- og Naturstyrelsen, København.

Welten, M., Sutter, H.C.R., 1982. Verbreitungsatlas der Farn- und Blütenpflanzen der Schweiz. Vol. 2. Birkhäuser, Basel.

de Wildeman, E., Durand, Th., 1899. Prodrome de la flore Belge. Tome III. Alfred Castaigne, Bruxelles.

Zarzycki, K., Wojewoda, W., Heinrich, Z., 1992. List of threatened plants in Poland (2 ${ }^{\text {nd }}$ ed.). Instytut Botaniki im. W. Szafera. Polska Akademia Nauk, Kraków. 